Portland State University

PDXScholar

Spring 5-23-2019

\title{
Simultaneous Bilingual Middle School Students Becoming Biliterate: What Do Students Think About Their Biliteracy as Taught Through the "Bridge" Strategy in a Humanities Dual Language/Immersion Class?
}

Alma Lucinda Diaz-Philipp

Portland State University

Follow this and additional works at: https://pdxscholar.library.pdx.edu/open_access_etds

Part of the Educational Leadership Commons, and the First and Second Language Acquisition Commons

Let us know how access to this document benefits you.

\section{Recommended Citation}

Diaz-Philipp, Alma Lucinda, "Simultaneous Bilingual Middle School Students Becoming Biliterate: What Do Students Think About Their Biliteracy as Taught Through the "Bridge" Strategy in a Humanities Dual Language/Immersion Class?" (2019). Dissertations and Theses. Paper 4980.

https://doi.org/10.15760/etd.6856

This Dissertation is brought to you for free and open access. It has been accepted for inclusion in Dissertations and Theses by an authorized administrator of PDXScholar. Please contact us if we can make this document more accessible: pdxscholar@pdx.edu. 
Simultaneous Bilingual Middle School Students Becoming Biliterate: What Do Students Think About Their Biliteracy as Taught Through the "Bridge" Strategy in a Humanities Dual Language/Immersion Class?

by

Alma Lucinda Díaz-Philipp

A dissertation submitted in partial fulfillment of the requirements for the degree of

Doctor of Education

in

Educational Leadership: Curriculum and Instruction

Dissertation Committee:

Dannelle D. Stevens, Chair

Micki M. Caskey

Joanne Cooper

Katrine Barber

Portland State University

2019 
(C) 2019 Alma Lucinda Díaz-Philipp 


\begin{abstract}
In response to the increasing number of United States school students from diverse linguistic and cultural backgrounds at all grade levels, often called "simultaneous bilinguals," the U.S. school districts are opening schools that offer bilingual instruction. One instructional strategy that seems promising is the "Bridge," where students contrast and connect the literacy skills learned in one language to the literacy skills in their other language. An underlying component of learning a language is student attitude and motivation to learn. Research also seems to indicate that student attitude and motivation toward biliteracy can affect their achievement. There seems to be a lack of research on how students respond to becoming biliterate. The purpose of this study is to explore how simultaneous bilingual middle school students respond to becoming biliterate in Spanish and English as a result of participation in a humanities dual language/immersion class, taught through the instructional strategy the Bridge. This study used a case study design. The focus was on 12 simultaneous bilingual middle school students who had at least three years of bilingual education. The methods used to gather data were: the students' achievement in biliteracy, a survey, a Draw-a-Bilingual-student activity, a narrative response, and a focus group. I identified five themes from the data analysis: (a) Positive role of family in developing biliteracy; (b) Confidence in becoming biliterate; (c) Using their biliteracy skills in the community; (d) Biliteracy valued for their future; and (e) Appreciation of bilingual programs in our schools. Future research should continue to
\end{abstract}


investigate the power of the Bridge strategy in furthering student success in becoming biliterate. 


\section{Dedication}

Für meinen Mann Andreas und unseren Sohn Daniel Antonio.

A nuestro hijo Daniel Antonio y a mi esposo Andreas. 


\section{Acknowledgements}

My doctoral journey took nine years and it could not have been possible without the support and encouragement of my professors, colleagues, friends, and family.

I am thankful to my dissertation advisor Dr. Stevens who sent me that "Do call!" message when I was ready to give up. I would also like to express my gratitude to Dr. Cooper for twice not letting me give up. I am grateful to both for their modeling, guidance, support, encouragement, feedback, and advice for the past five years. My sincere thanks to Dr. Caskey for her detailed feedback and insightful comments. I appreciate her time and support. My grateful thanks to Dr. Barber for her support and participation in my committee.

In addition, I would also like to thank Dr. de la Vega for her support for my core paper and enthusiastic encouragement and useful feedback for my dissertation. My gratitude to Dr. Henry whose expertise in policies and politics provided me with a very valuable lesson for my core paper.

A special mention to the late Dr. Emily de la Cruz, my former advisor, who could not see my final core paper but wished me a successful doctoral journey.

The assistance provided by Stefanie Randol from the College of Education and Shannon Roth from Office of Research Integrity and Institutional Review Board was greatly appreciated.

My special thanks are extended to my students and their families that agreed to participate in my study. Together, we have contributed to the growing literature on 
bilingual education. Muchas gracias queridxs estudiantes y a sus familias por su apoyo. Les deseo mucho éxito.

My sincere thanks go to all my colleagues and friends who have supported me in many different ways throughout this journey: JoAnna Flores, Rayna Flye, Susan Duncan, Susan Baglin, Tiffany Tran-Parta, Eric Ruiz, Michael Fleming, Paulina Gutierrez, Ninive Morales, Abel Pacheco, Einar Pacheco, Lorena Santacruz, Aimee Carreon-Serna, Candelaria Lujano. My classmates in EdD 607 for their example and support. Gracias Tatiana Cevallos por ayudarme con mi tema, la redacción, las presentaciones y cuidar mi hijo.

Con infinita gratitud a mis padres Rosa María Mayo y Jorge Alberto Díaz por su apoyo, por su paciencia y por crear recuerdos y enseñanzas maravillosas con Daniel mientras yo trabajaba en la conclusión de esta meta. Gracias a Georgina Díaz Mayo y la familia Díaz Torrescano por dejar su día a día para acompañar a Daniel en esta etapa.

Vielen Dank an Ute und Walter Philipp dafür, dass sie nach Amerika kamen, um zu helfen, als ich angerufen hatte. Ich bedanke mich für ihre Zeit bei uns und für alles, was sie Daniel während ihrer Besuche beigebracht haben. Lieber Walter, vielen Dank, dass du meine Doktorarbeit gelesen hast und für deine Tipps, wie ich mein Englisch verbessern kann. Vielen Dank, liebe Familie Rauch, für eure Unterstützung und Ermunterung.

Meine unendliche Dankbarkeit gilt meinem Mann Andreas, der lange Nächte an meiner Seite verbracht hat, ohne geschlafen zu haben. Er hat meine Ideen durchgesehen, die englischen Texte überarbeitet und das Dokument formatiert. Weiterhin hat er Daniel 
auf seine Partys begleitet und mich bei allem unterstützt, was nötig war, um mit meiner Doktorarbeit voranzukommen. Herzlichen Dank, lieber Andreas.

Y a mi querido hijo Daniel por compartir esta etapa en que solamente ha conocido a su madre como "estudiante de doctorado." Gracias por tu apoyo. Hijo, te quiero mucho. 
Table of Contents

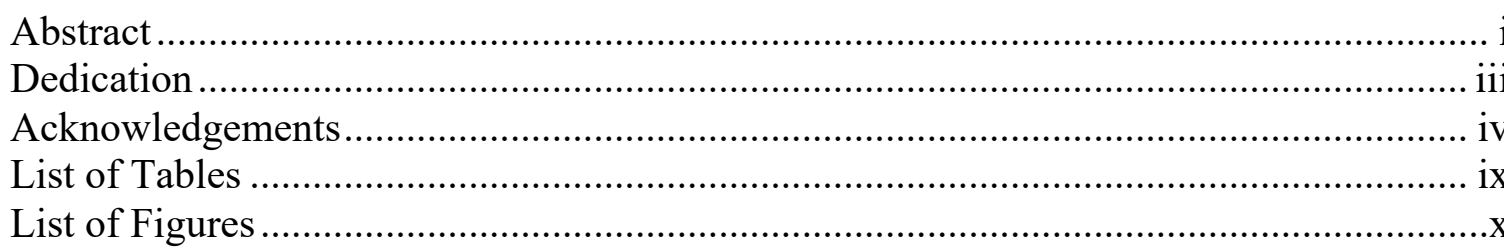

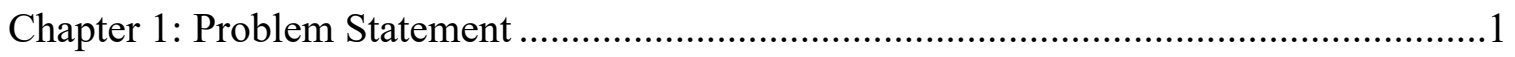

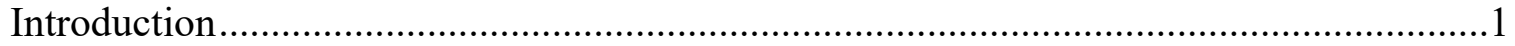

Background of the Problem .........................................................................................

Validation of the Problem ......................................................................................

Research Statement ............................................................................................ 13

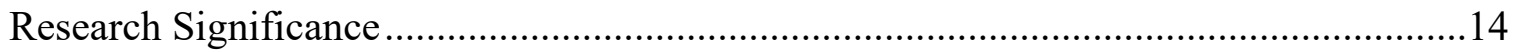

Presentation of Methods and Research Question......................................................16

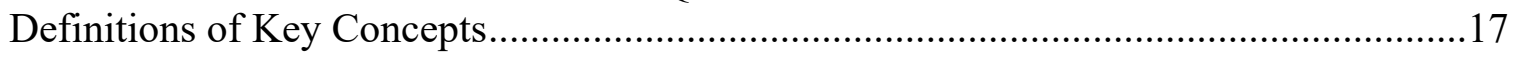

Chapter 2: Literature Review ............................................................................. 21

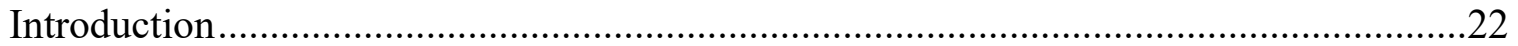

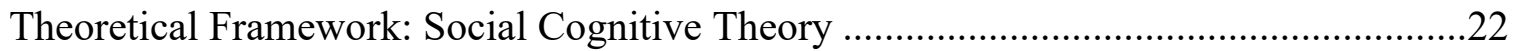

Review of the Research Literature..........................................................................25

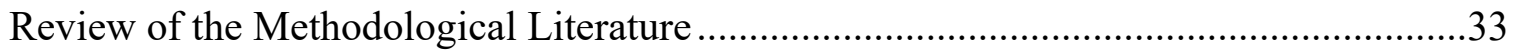

Summary of the Research Literature and Its Applications to This Study.........................34

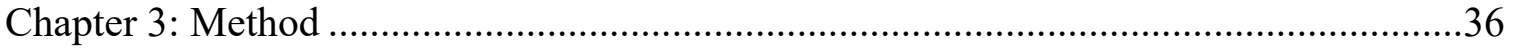

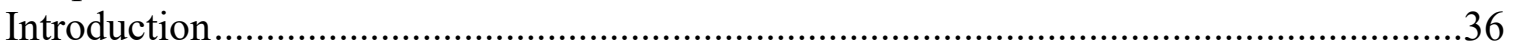

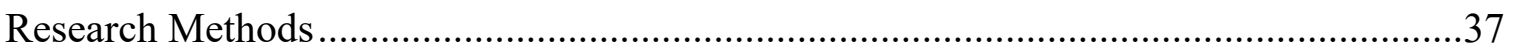

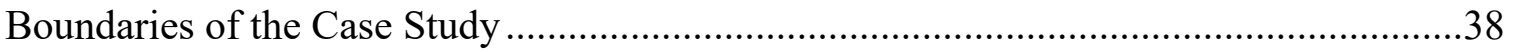

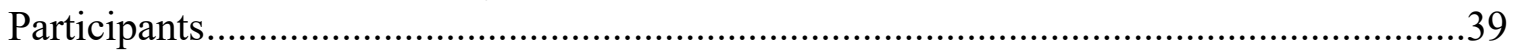

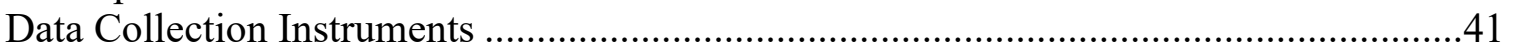

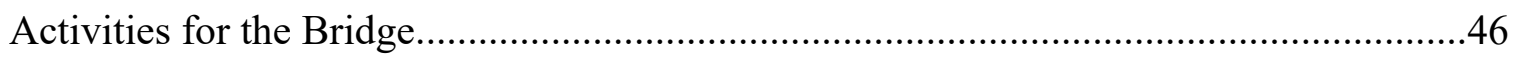

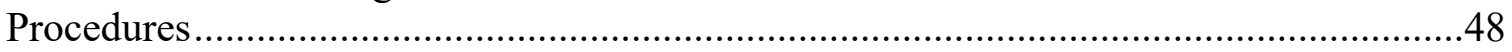

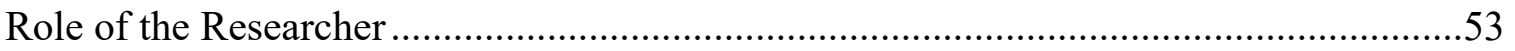

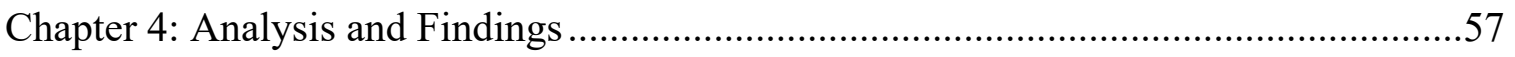

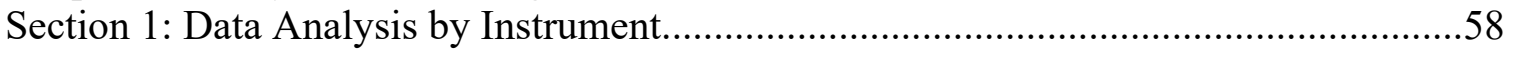

Section 2: Overarching Themes Across All Data Sources ...........................................70

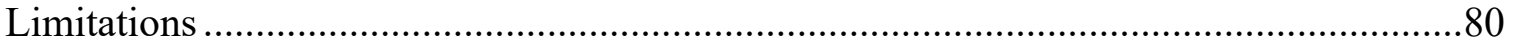

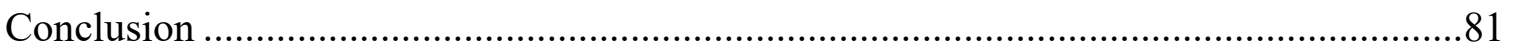

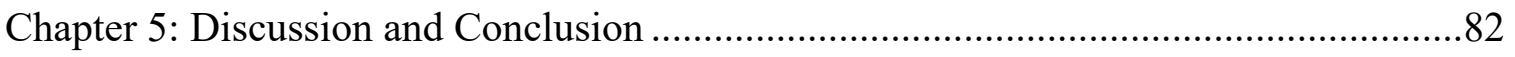

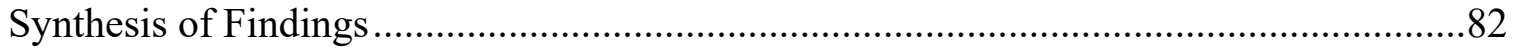

Implications of the Instructional Strategy the Bridge to Advance Biliteracy ...................84

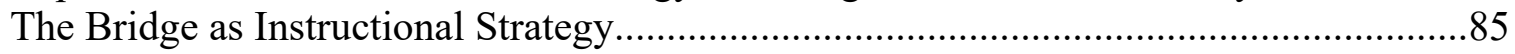




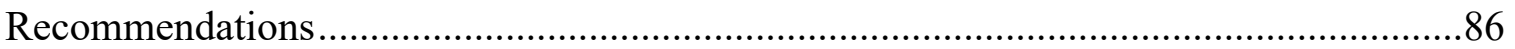

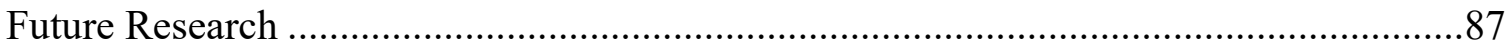

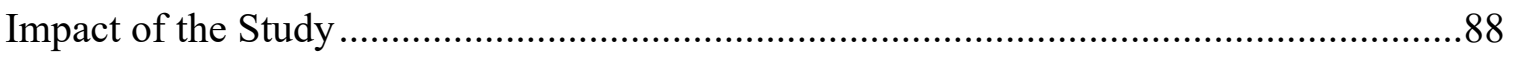

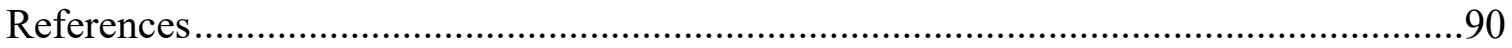

Appendix A: Verbal Recruitment Script..............................................................96

Appendix B: Guión Para Reclutamiento de Candidatos Para Estudio ............................100

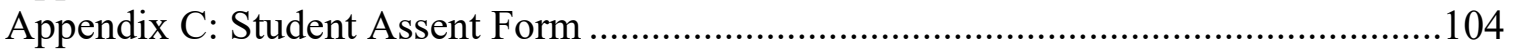

Appendix D: Formulario de Asentimiento del Estudiante..........................................108

Appendix E: Parent and Guardian Consent Form..................................................110

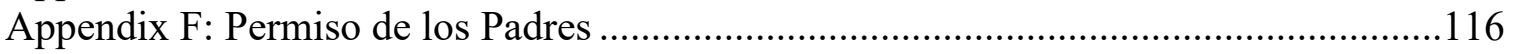

Appendix G: Lesson Plan to Use the Bridge Instructional Strategy .............................121

Appendix H: Narrative Writing Checklist ..............................................................123

Appendix I: Survey in Form of a Verbal Scale Response .........................................125

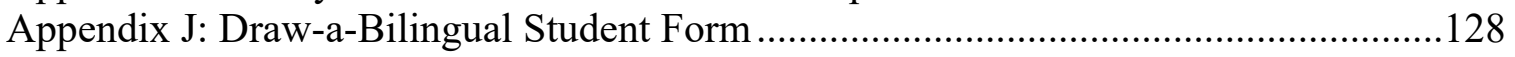

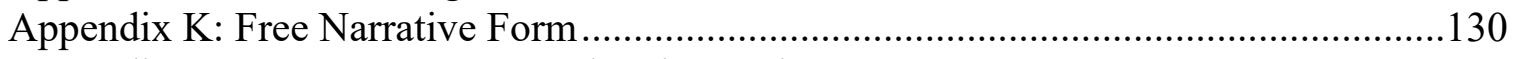

Appendix L: Focus Group Protocol and Questions .................................................133

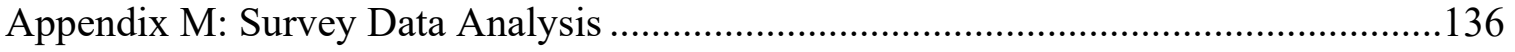

Appendix N: Students' Draw-a-Bilingual-Student Pictures and Narratives.....................140

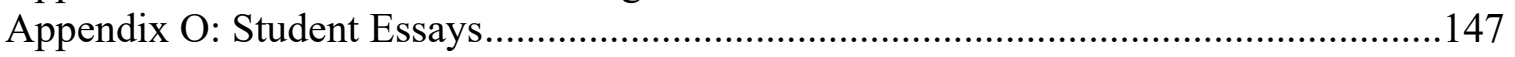

Appendix P: Oregon State Seal of Biliteracy ......................................................... 152 


\section{List of Tables}

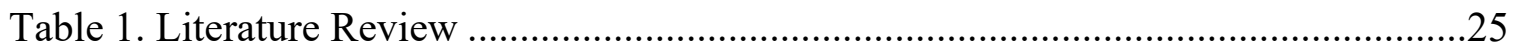

Table 2. The Bridge in a Narrative Text Lesson: Writing About the Influence of Our

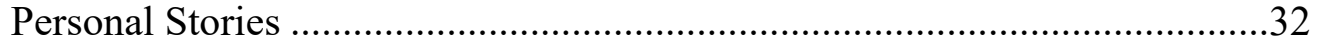

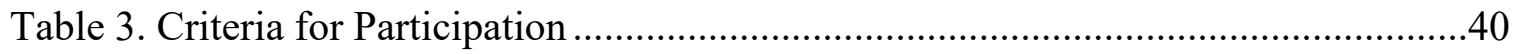

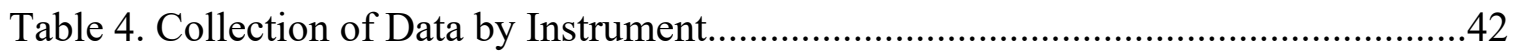

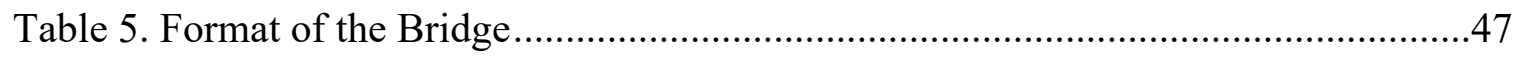

Table 6. Students' Achievement in Biliteracy: Scores Across the Three Dimensions

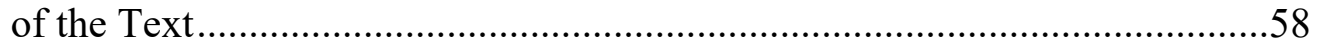

Table 7. The Four Dimensions on Survey in a Likert Scale..........................................60

Table 8. Occurrence of Codes in Focus Group.............................................................69

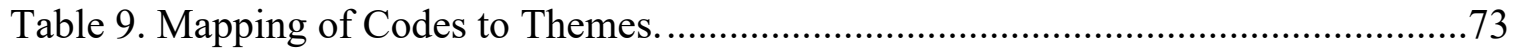

Table 10. Overarching Themes Derived from the Survey, Draw-a-Bilingual-Student, Free Narrative and Focus Group.............................................................74

Table 11. Occurrence of Codes Per Theme in Narratives ...........................................76

Table 12. Occurrence of Codes Per Theme in Focus Group .........................................76 
List of Figures

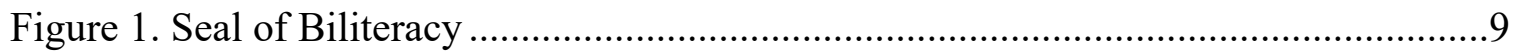

Figure 2. Number of Languages Spoken in the 15 Largest Metro Areas .........................10

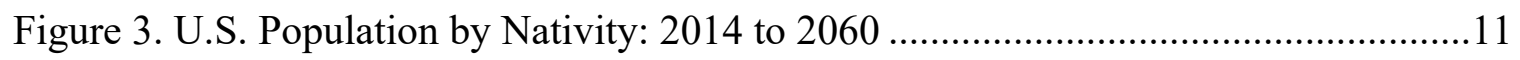

Figure 4. Most Spoken Languages in Oregon in 2010 ..............................................12

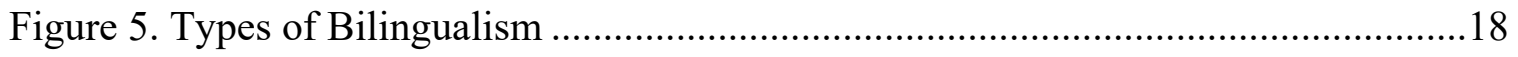

Figure 6. Types of Common Language Programs in K-12 Schools ...............................19

Figure 7. Relations Between the Three Determinants With Guiding Questions for

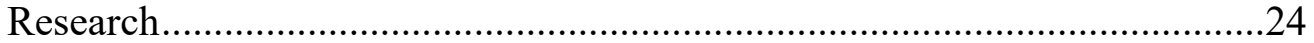

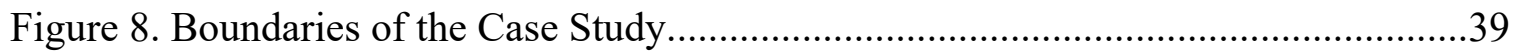

Figure 9. Study Procedures That Include the Type of Data Collected and the Order in Which it Was Collected...........................................................................50

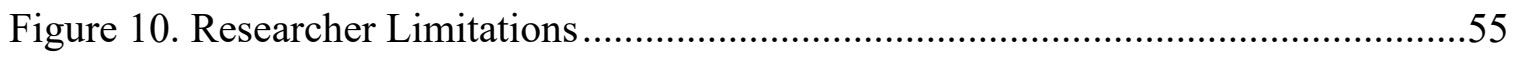

Figure 11. Thematic Networks: An Analytic Tool for Qualitative Research ...................56

Figure 12. Labels Identified in Students' Drawings of a Bilingual Student....................62

Figure 13. Minerva's Drawing and Her Free Narrative.............................................64

Figure 14. Julio César's Drawing and His Free Narrative..........................................65

Figure 15. Xóchitl's Drawing and Her Free Narrative. ...........................................66

Figure 16. Code Occurrence in Personal Narratives of Draw-a-Bilingual-Student...........67

Figure 17. Overarching Themes of the Study ......................................................... 71 


\section{Chapter 1: Problem Statement}

The increasing number of students that speak at least one more language other than English in the United States' classrooms is increasing. I see this as an opportunity to maximize the linguistic talents that students already possess. Therefore, in this study I researched how to better support simultaneous bilingual students to advance biliteracy in a dual language/ immersion class. In this chapter, I will explain the background of the problem and its historical context. Next, I will explain the national and local support, and discuss why this is a problem in our schools. Finally, I will present my guiding research question and the definition of key concepts in this study.

\section{Introduction}

Over many years, as the United States assumed world leadership, a need has developed for U.S. schools to graduate globally competent students (Collier \& Thomas, 2009; Kleyn, López, \& Makar, 2015; Koda \& Zehler, 2008; Vásquez, Hansen, \& Smith, 2013; Woodrich \& Fan, 2017). At the same time, U.S. schools have become more diverse (Collier \& Thomas, 2009; Koda \& Zehler, 2008; Park, Zong, \& Batalova, 2018; Vásquez et al., 2013; Wei, 2010; Woodrich \& Fan, 2017). The U.S. school districts are finding that there is an increase in the number of languages spoken within their regions as well as in the number of students who are bilingual (U.S. Census Bureau 2015a). Some of the students who speak or understand more than one language could be emergent or simultaneous bilinguals. Simultaneous bilinguals are children 3 or more years of age whose home language is a language other than English. At the same time, simultaneous 
bilinguals are also children who are exposed to two or more linguistic codes prior to the age of 5, either through circumstances or their family's choice. Escamilla et al. (2014) explained that if children in U.S. schools are exposed to biliteracy as simultaneous bilinguals from preschool onward, they will become simultaneous bilinguals.

In response to the increasing number of students from diverse linguistic and cultural backgrounds and needs in U.S. schools, the U.S. school districts are responding by opening up new programs to meet the challenge of educating both emerging and simultaneous bilinguals (Escamilla et al. 2014). For Gándara and Escamilla (2017), the purpose of dual language programs in the United States is to develop biliteracy in all students, regardless of the question whether they speak a language other than English at home or only English. However, a much-debated question is whether the students who have diverse linguistic and cultural backgrounds should be in programs that include their own home language or whether they should be immersed in English-only courses that disregard their home language. Some scholars believe that school programs should be conducted in English only, as demonstrated by "English-only educational policies" (Daniel \& Pacheco, 2016, p. 655). In contrast, numerous examples of research have consistently shown that immersing the students from diverse linguistic and cultural backgrounds into courses in which they cannot understand the content is holding them back academically (C. Baker and Wright, 2017). Others claim that they do not acquire new skills that would allow them to meet their grade level requirements as well as national standard benchmarks (C. Baker and Wright, 2017). However, there is a significant amount of research that indicates that the students who are literate in two 
languages outperform their monolingual peers over time (Collier \& Thomas, 2009; Koda \& Zehler, 2008; Vásquez et al., 2013; Woodrich \& Fan, 2017).

One issue is the question - at what grade level should school districts begin their programs to support students? Most of them begin at the elementary and preschool level. However, even though districts begin at an early level, in my experience as a bilingual educator there is evidently also a need to understand how the U.S. school districts can support their students at the middle and high school levels, too. The demand to expand secondary immersion programs has increased in recent years (García \& Kleifgen, 2018).

The purpose of this study is to explore how simultaneous bilingual middle school students respond to becoming biliterate in Spanish and English as a result of participation in a humanities dual language/immersion class, taught through the instructional strategy the "Bridge".

\section{Background of the Problem}

Until now, the goals of dual language/immersion programs have been to promote fair practices for English language learners or limited English proficiency students. However, the simultaneous bilingual and sequential bilingual student population numbers are rising. According to the Migration Policy Institute, the simultaneous bilingual students represent around "one-third of all young children ages 8 and under in the United States" (Park, Zong, and Batalova, 2018, p. 1). For these simultaneous bilingual students, who were born in the U.S. and have at least one parent that speaks at least one language other than English at home, the educational reality at school becomes bilingual. This shows that there is a need to continue researching and developing the dual 
language/immersion programs to improve the educational opportunities for and to enhance the bilingual skills in the simultaneous bilingual students.

Consequently, the question arises, what kind of educational program works best for simultaneous bilingual students? Prior research suggests that students need "explicit teaching and interactive strategies instead of a process approach" (Escamilla et al. 2014, p. 53) to develop biliteracy. In other words, students need close and intentional modeling and guiding instruction, instead of sequential actions of a pre-established curriculum (Escamilla et al., 2014). One issue is that the background and skills that an instructor needs to guide biliteracy require a different teaching skillset than the one that typical monolingual educators possess.

When there is a skilled teacher, there are also programs that offer hope for these students. However, only limited research at the secondary level discusses how schools use the Bridge strategy, which includes multiple strategies that simultaneous bilingual students can use such as translanguaging, code-mixing/code switching, word recognition, word association, cognates, and Spanish and English dictados (Escamilla et al., 2014; G. E. García \& Godina, 2017). The focus of the Bridge strategy is to employ one language to explain the other or-transference. To understand where we are today in selecting the best programs for bilingual students, it is best to look at the history of bilingual school programs in the United States.

The historical context. The historical and sociopolitical events in the United States have shaped today's world language programs in general (Baker, 1978; C. Baker \& Wright, 2017; Beeman \& Urow, 2013; Hamayan, 1986; Heining-Boynton, 1990; Moulton, 1962; Rhodes, 1991; Rosenbusch, 2012). From the end of the 19th century to 
today, world language programs were an essential component of the education curricula as well as a constant source of controversy, both inside and outside of the education field.

During the first half of the 20th century in the United States, world language programs offered limited language choices. Even though the United States had already become a "world power," the interest in learning world languages was not high among its citizens (Moulton, 1962, p. 96). Research shows that the political agendas and personal interests of government leaders had impacted all language programs in U.S. schools throughout history (C. Baker and Wright, 2017, p. 173). However, over the years, the United States slowly adopted language learning as part of its standard curriculum. In 1942, the Army Specialized Training Program recommended adding world language programs in elementary and secondary school curricula as well as teacher training programs. The National Defense Education Act, passed in 1958, aimed at strengthening the modern language, science, and mathematics programs. By the late 1960s, there were only a few foreign language programs in elementary schools (Andrade \& Ging, 1988; R. E. Baker, 1978; Curtain, 1990).

Law cases have helped strengthen bilingual education and make cultural impact in the communities that the U.S. school districts serve. The cases of Mendez et al. vs. Westminster School District of Orange County et al. in 1947 (Aguirre, 2005) and Brown vs. Board of Education in 1954 (C. Baker and Wright, 2017), opened the pathway toward the end of school segregation based on race and nationality. The Immigration and Nationality Act of 1965 (C. Baker and Wright, 2017) stopped all ethnic background criteria for admission and emphasized family unification that provides funding to support bilingual programs. The Bilingual Education Acts of 1968 and 1974 (C. Baker and 
Wright, 2017) provided funds for transitional language education programs not for the maintenance of dual language programs. The Lau vs. Nichols case in 1974 (C. Baker and Wright, 2017) ultimately provided equal access opportunities for all language minority students. The Civil Rights Language Minority Regulations were created in 1980 (Levin, 1982), while the Carter Administration attempted to formalize its support for bilingual education, only to have the subsequent Reagan Administration withdraw that support. The 1981 Castañeda vs. Pickard (C. Baker and Wright, 2017) case established that the "Programs for limited English proficient students (bilingual or otherwise) must be: (a) based on sound educational theory, (b) implemented with adequate resources, and (c) evaluated and proven effective" (C. Baker and Wright, 2017, p. 188). In 1988 and 1994, the Bilingual Education Act Title VII or ESEA (Baker and Wright, 2017) was reauthorized. In addition, C. Baker and Wright (2017) explained that California (1998), Arizona (2000), and Massachusetts (2002) all passed initiatives that ended most bilingual programs to impose English only education.

Even though dual language/immersion programs exist in U.S. schools today, they face some challenges. Some of these challenges include a lack of funding, continuous curriculum changes, a lack of qualified teachers, unrealistic and inappropriate goals and objectives, incompatible pedagogy, a lack of articulation, a lack of accountability, a lack of leadership support, and a lack of parental support (Andrade \& Ging, 1988; R. E. Baker, 1978; Curtain, 1990).

The support of dual language/immersion programs in Oregon. In Oregon, the Department of Education has supported further improving and expanding the dual language/immersion programs in the state. It has instituted channels to support districts in 
recruiting teachers, promote dual language/immersion programs, and recognize the hard work that enables the students to complete their education in two languages (Oregon Department of Education, 2014a). There are several examples of how the Oregon Department of Education supports dual language/immersion programs in the state's public schools.

First, the Oregon Department of Education (2016a) published a guide for its school districts that work with English language learners. This guide explains that the primary goal of dual language/immersion programs is to develop fully bilingual and biliterate students. The document provides information for parents as well as for teachers, administrators, and the community. In 2013, seven Oregon districts received grants to design, improve, and expand their dual language programs. Given the support, there are opportunities to refine instruction in dual language programs across the state. The grant also supports university teaching programs, such as the Bilingual Teacher Pathway, to prepare highly qualified bilingual teachers in different subject areas. Teachers in bilingual education study the linguistic theories of how human beings learn and acquire languages more in-depth to enable them to maximize the cultural and linguistic backgrounds of their students in the classroom. Furthermore, the Oregon Department of Education offers an international exchange program. This program is a partnership with Spain, Mexico, and China. It invites teachers from these three countries to work in Oregon schools, supporting academic and cultural exchanges in the classroom for up to three years with visitor visas.

Second, the Oregon Department of Education uses funds from Title III of the ESEA support initiatives to enable school district leaders and researchers to work 
collaboratively with teachers to develop a research-based curriculum that supports biliteracy. The school districts provide the teachers with professional development by attending bilingual conferences and allowing for the time needed to work collaboratively. In addition, the teachers and administrators work together to measure the advancement and progress of academic content as well as language proficiency advancement.

Finally, the Oregon Department of Education recognizes the students' efforts to complete their education in two languages by offering an award for studying a second language. The purpose of this award is to incentivize the students to study world languages and to provide them with an official document that validates their bilingualism for future college or job applications. The Oregon Department of Education awards the Seal of Biliteracy (see Figure 1) to its graduating high-school seniors. The Seal of Biliteracy requires the students to complete all high school requirements in addition to providing evidence of proficiency in English and the target language in four domains: reading, writing, listening, and speaking. In Oregon, the target language can be Chinese, French, German, Japanese, Persian, Russian, Somali, Spanish, Ukrainian, and Vietnamese. In addition, the students submit their language portfolios and assessments to become eligible for receiving the Seal of Biliteracy award upon graduation. Figure 1 shows the Seal of Biliteracy and the growing number of students that seek to graduate with the seal. 


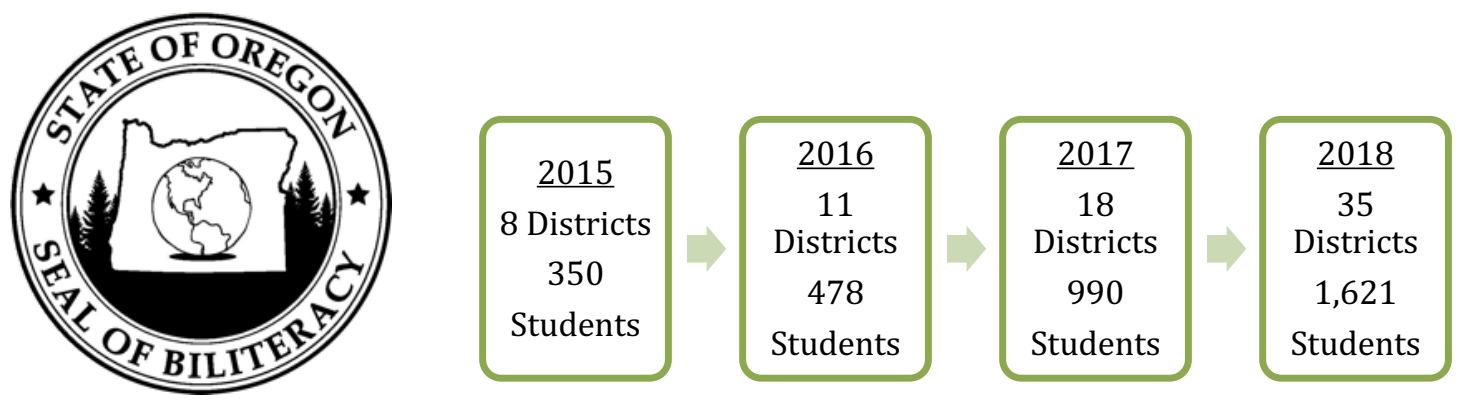

Figure 1. Seal of Biliteracy. From Oregon Department of Education (2016b).

\section{Validation of the Problem}

Despite the support for bilingual education, Hispanic English language learners have the lowest graduation rates and the highest dropout rates in schools (McFarland et al., 2017). In addition, their achievement falters through the school years (McFarland et al., 2017) even though their population is increasing. As a result of the research on the power of biliteracy, it seems that one way to address this critical problem is to offer highquality dual language/immersion programs.

Simultaneous bilingual students are becoming the "new normal" of school population in the United States (Escamilla et al. 2014, p. xi). Previously, most bilingual students were sequential bilinguals, which means that a person learned a language after the age of 7. Today, especially through the increase in multicultural families speaking languages other than English at home, we predominantly have simultaneous bilinguals in the classroom, which means that the majority of students grow up listening and speaking a language or languages other than English at home since birth. New generations of bilingual students in the United States are born to multicultural families. According to Corona et al. (2012), it is projected that by $2020,20 \%$ of youth in the United States will 
have had at least one foreign-born parent who speaks a language other than English.

Berliner and Biddle (as cited in Collier and Thomas, 2009) mentioned that the U.S.

Census predicted that student speakers of languages other than English would make up $40 \%$ of the student population by the 2030s. This estimate equals two of every five students. According to Escamilla et al. (2014), we are currently at a ratio of 1 in 10 students.

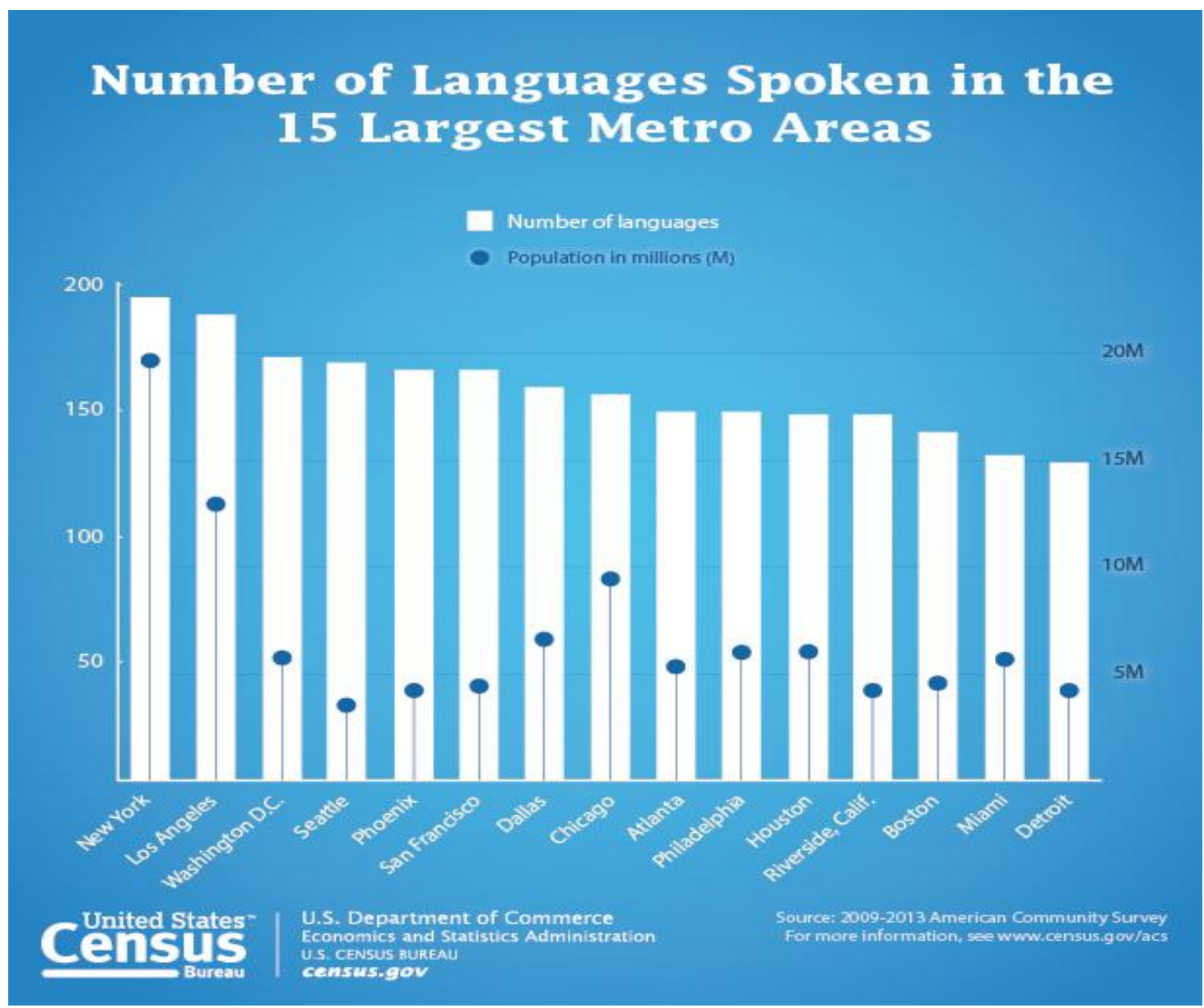

Figure 2. Number of languages spoken in the 15 largest metro areas. Reprinted from the U.S. Census Bureau (2015b) 
These students are learning two or more languages simultaneously because the language or languages used at home are additional to the English language they use in everyday life situations outside the home environment. Figure 2 shows the U.S. Census Bureau's (2014) statistics for world languages spoken in 15 large metro areas in the U.S. and the population.

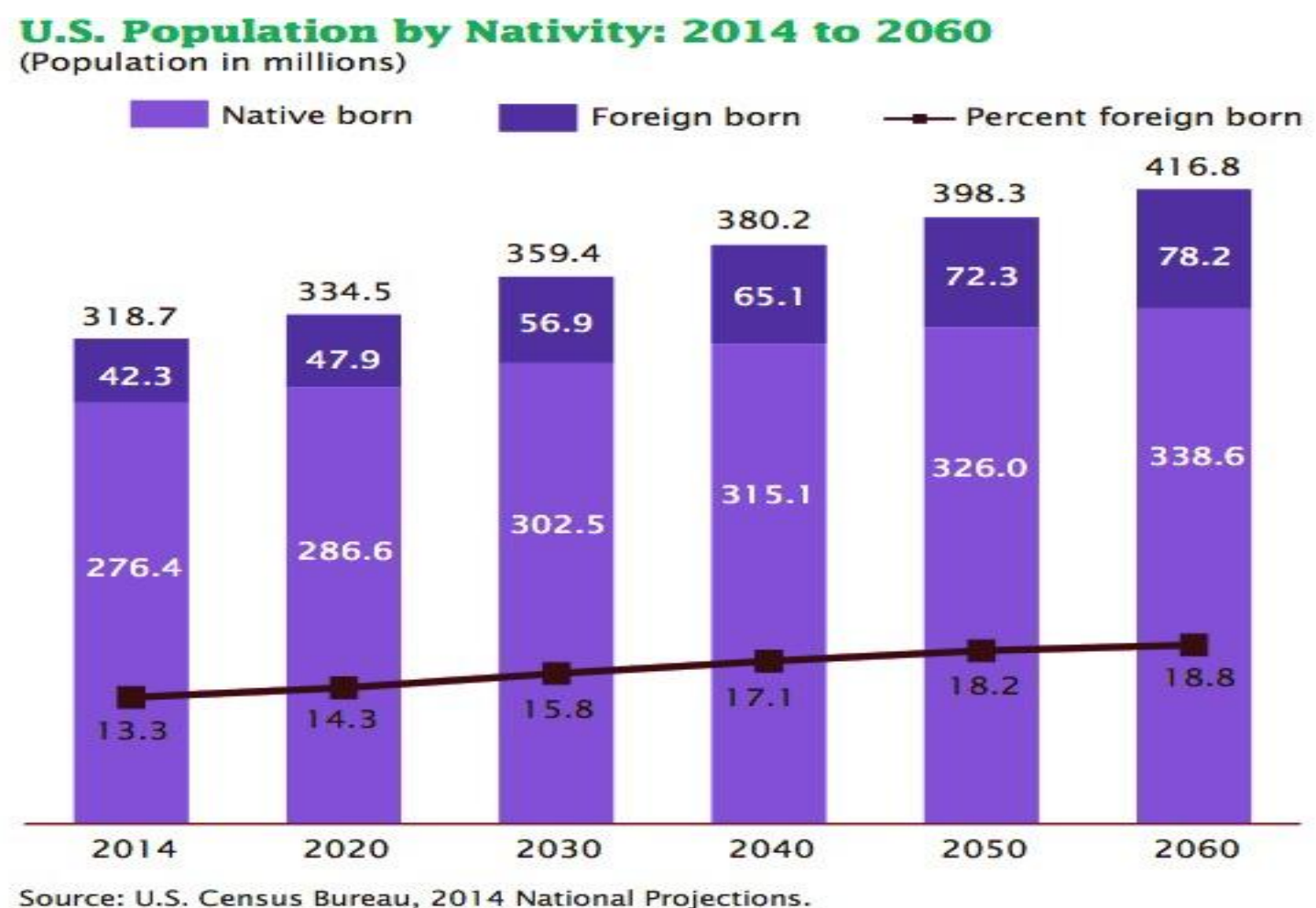

Figure 3. U.S. population by nativity: 2014 to 2060 . Reprinted from the U.S. Census Bureau (2014).

Figure 3 shows that there has been a 19\% growth in foreign-born population over the past 46 years. For bilingual education programs, this means that even more students with bilingual or multilingual backgrounds will be joining U.S. schools by 2060 (U.S. Census Bureau as cited in Colby \& Ortman, 2014). Combining Figures 2 and 3 shows the 
continual increase in the number of bilingual students in our schools. These data seem to indicate that there is a need for more bilingual programs in U.S. schools that would benefit the students from diverse backgrounds.

Figure 4 shows that, according to the Modern Language Association 2010 survey, $85.63 \%$ of people over 5 years of age speak English in Oregon. In addition, it also shows that the cultural diversity is large and that $14.37 \%$ of the students in Oregon schools speak languages other than English. According to The Productividad District, student population alone speaks 101 languages in the 2018-2019 academic year.

\section{Most spoken languages in Oregon in 2010}
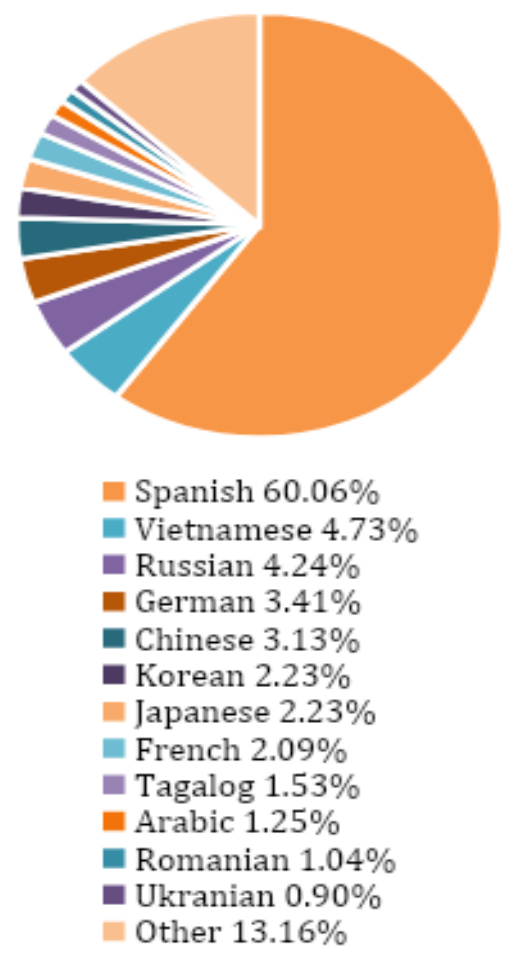

Figure 4. Most spoken languages in Oregon in 2010. Adapted from the Modern Language Association (2010) Language Map Data Center. 
According to the Oregon Department of Education (2014b), there are more than 80 dual language programs in Oregon. As an indicator of the increase in biliteracy in the state, in 2017-2018, thirty-five districts awarded 1,621 biliteracy awards. The majority of the awards were for those students who were proficient in two languages, while eight were awarded for proficiency in three languages and two for proficiency in four languages. In addition, according to an analysis by the Education Week Research Center of NCES data, $67 \%$ of simultaneous bilinguals graduated from high school during that same academic year in comparison to $85 \%$ of the overall student population graduating from high school (Decker, 2017).

\section{Research Statement}

The research problem addressed in this paper is the fact that Hispanic English language learners have the lowest graduation rates and the highest dropout rates in schools (McFarland et al., 2017). In addition, their academic achievement falters through the school years (McFarland et al., 2017) even though their population is increasing. As a result of the research on the power of biliteracy, it seems that one way to address this critical problem is to offer high quality dual language/immersion programs. Some current research has identified several strategies to help these students develop biliteracy at all levels. Furthermore, the majority of the research activities on these programs has been done at the elementary school level. In middle schools, the students must grapple with content in subjects such as humanities, science, and mathematics. One of the challenges found within the dual language programs is that this complex content needs to be taught and assimilated in both languages. 
To protect the identity of my participants, from now on I will use the pseudonyms Éxito Middle School and Productividad School District. I use the Bridge strategy in the Éxito Middle School program in which I work as a Humanities dual language teacher. However, there has not been a systematic study of how students respond to this unique strategy for the dual language/immersion programs. The Migration Policy Institute mentions the importance of attending to the multicultural diversity that is populating the U.S. classrooms, beyond just attending to what has thus far been called "English Language Learners" or "Limited English Proficient" students. The effects of migrations in the classroom is "where society's response will determine the skills of the future U.S. workforce and the nation's ability to remain competitive in a global economy" (Park et al., 2018). The reality of multicultural and multilingual classrooms demands a set of different teaching strategies that do not see the students' linguistic and cultural differences as barriers but as assets that can assist in the students' learning. Unless we can make that shift, our future generations will not be able to compete in a globalized world.

\section{Research Significance}

Globalization, with its rapid changes worldwide, creates an opportunity to capitalize on assets that many of our students already possess. As mentioned before, new generations of bilingual students in the U.S. are born to multicultural families. These new generations of Americans are already acquiring fluency in other languages in addition to English even before they start school. It is a practical idea to capitalize on the language skills and on the cultural understandings already possessed by those students. 
Schools are becoming more diverse and the number of multilingual students is projected to continue increasing (Koda \& Zehler, 2008). Reading and writing in more than one language are essential skills for a person to be considered bilingual. In our schools, we have a large proportion of students from a Hispanic heritage background for whom Spanish is the language spoken at home while their teachers and friends speak English. By offering courses that can help them capitalize on their knowledge of two languages, we are increasing their chances to become truly bilingual. To capitalize on the students' social language already acquired at home, a truly bilingual student needs to have the opportunity to be instructed in developing both cognitive and academic language proficiency in the home language as well as English.

A truly bilingual individual is literate in two language domains. To achieve this goal, a bilingual program could implement a bridging technique to advance its students' literacy. Through this study, I explored how the students respond to the Bridge strategy created for Spanish dual language middle school students and what factors increase their success in these classes, aiming to advance the field of bilingual/dual language education at the middle school level.

Multicultural connections resulting from globalization have contributed to raising awareness of the needs to nurture bilingualism in education as an option for progress. Wei (2010) found that some of the factors that can motivate simultaneous bilingual students to become biliterate are the result of family choice or external consequences, such as: (a) political, (b) natural disaster, (c) religious, (d) cultural, (e) economical, (f) educational, or (g) technological ones. Bialystok (1994) mentioned the special situation 
of simultaneous bilinguals in some circumstances, for example, when these children are born to a multicultural family or when their regional linguistic environment blends to take linguistic diversity as "the norm" (Wei, 2010, p. 1). As previously mentioned, the U.S. Census Bureau (2014) has projected that the number of children born to at least one foreign parent will increase. In the case of the United States, according to Thomas and Collier (2012), "dual language schooling represents the best of all possibilities for uniting the needs of many diverse groups" (p. 23).

\section{Presentation of Methods and Research Question}

Creswell (1998) defined qualitative research as

an inquiry process of understanding based on distinct methodological traditions of inquiry that explore a social or human problem. The researcher builds a complex, holistic picture, analyzes words, reports detailed views of informants, and conducts the study in a natural setting. (p. 15)

I used qualitative methods to capture the authentic voices of simultaneous bilinguals. I used five methods to collect data: academic achievement artifacts, a survey, a focus group, a draw-a-bilingual student activity, and a free-narrative. My main research question for this study is: How do simultaneous bilingual middle school students respond to becoming biliterate when taught using the Bridge strategy in a humanities duallanguage/immersion class? The sub-questions of the study are: What do students' achievement scores tell me about developing biliteracy using the Bridge strategy? What attitudes do students have toward becoming biliterate? How do students transfer literacy skills learned through the Bridge to new situations in the other language? How do students respond to becoming biliterate in the context of using the Bridge strategy? 


\section{Definitions of Key Concepts}

Historically, depending on the political agenda, the students who speak a language other than English have been referred to as English Language Learners, Limited English Proficient, or English Learners. According to a definition provided by the "Every Student Succeeds Act” (ESSA, 2015), as cited by O. García and Kleifgen (2018), English learners are:

Students age 3-21, enrolled in elementary or secondary education, born outside of the United States or speaking a language other than English in their homes, and not having sufficient mastery of English to meet state standards and excel in an English-language classroom. (p. 5)

Figure 5 shows a classification of a bilingual person. A bilingual person can be simultaneous or sequential bilingual if that person was exposed to two or more languages from any time between birth up to reaching the age of 12 . A late sequential bilingual would be a person who learned a language or languages any time after reaching the age of 12 . 


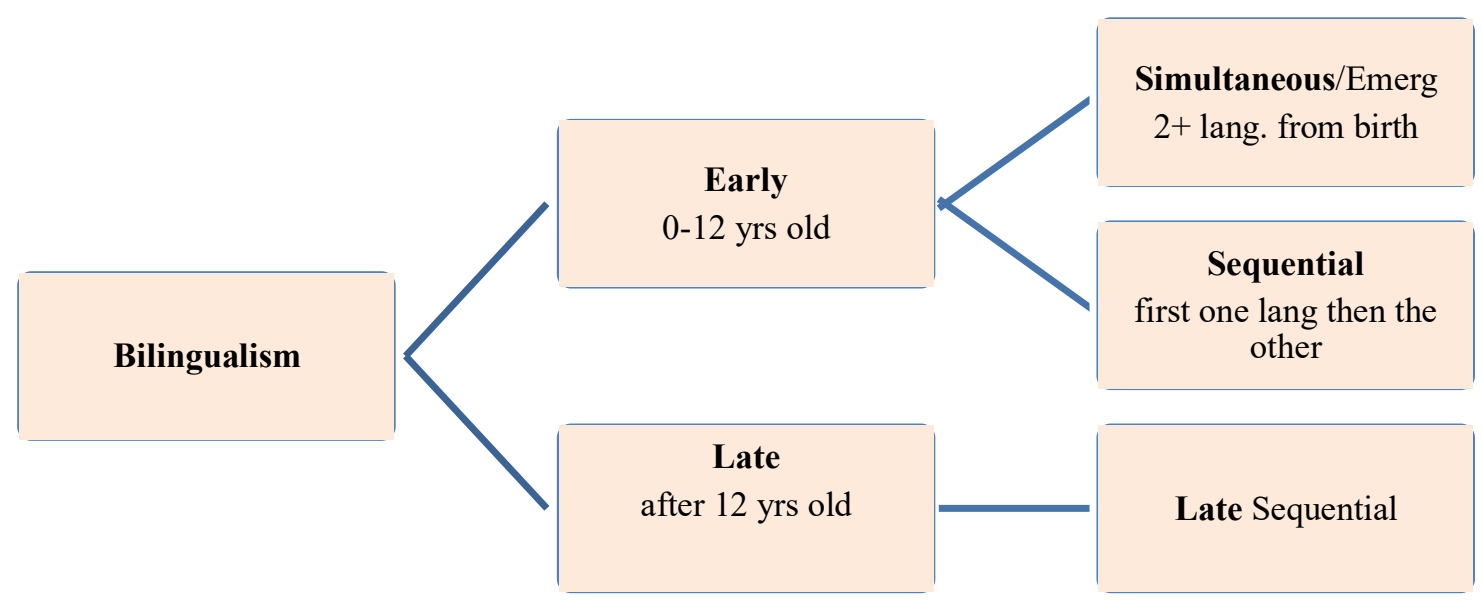

Figure 5. Types of bilingualism. Adapted from Montrul (2013). El Bilingüismo en el mundo hispanohablante.

In this dissertation, the definition of simultaneous bilinguals takes into account the views of Escamilla et al. (2014), Cummins (2018), Beeman and Urow (2013), and O. García and Kleifgen (2018). Hence, I define "simultaneous bilinguals" as those students who are 3 or more years old and who are exposed to one or more languages other than English at home and in their communities, thus having the choice to develop biliteracy at school, in English and another language—in my case Spanish.

Dual language/immersion programs are examples of curricula designed to meet the needs of particular students. For Thomas and Collier (2012), dual language/ immersion programs "represent the best of all possibilities" (p. 23) for a simultaneous bilingual to develop literacy in two languages. In addition, they also find that dual language/immersion programs are "the most powerful school reform" (p. 27) for the promotion of higher achievement on the standards set by the Common Core State 
Standards for English language arts, science, math, and social studies (Valdés, Menken, \& Castro, 2015).

Figure 6 shows three different models in U.S. schools that promote languages. Exploratory language programs provide a world language instruction to students in a limited model, it allows as its name indicates for exploration only. Language focus programs promote learning of a world language in a limited, scatter schedule in a week throughout a school year. Dual language/immersion programs provide instruction 90/10, $80 / 20$, or $50 / 50$ percent of the time in a language other than English within a community where the official language is English, and the programs promote literacy skills in English and another language.
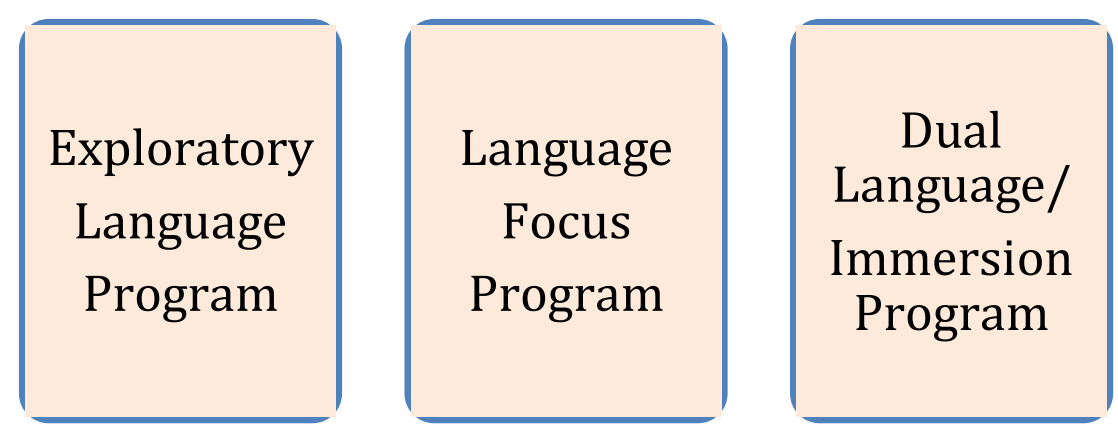

Figure 6. Types of common language programs in $\mathrm{K}-12$ schools.

Translanguaging is an example of an instructional strategy used to help students learn another language. Translanguaging is the practice of students and teachers using one's own or the group's literacy in multiple languages when teaching and learning. O. García, Johnson, and Seltzer (2017) suggested a translanguaging pedagogy based on the three concepts of translanguaging: translanguaging corriente, dynamic translanguaging progressions, and translanguaging stance, design, and shifts. 
Translanguaging corriente refers to the question how the interplay between leveraging the various languages for learning plays out in the classroom. The concept of a dynamic translanguaging progression refers to a way of capturing and understanding a student's bilingual practices in oracy and literacy. García et al. (2017) explored how teachers with a translanguaging stance design their lessons to leverage the translanguaging corriente and shift their teaching strategy as the translanguaging corriente changes course.

The Bridge is an example of an instructional strategy that can be used to help students learn another language. According to Beeman and Urow (2013) the Bridge is: the instructional moment in teaching dual language when teachers bring the two languages together, guiding students to engage in contrastive analysis of the two languages and transfer the academic content they have learned in one language to the other language. Bridging involves the use of cross-linguistic strategies and leads to the development of metalinguistic awareness. (p. 1)

Furthermore, according to Beeman and Urow (2013), "translanguaging...is more flexible and spontaneous than the Bridge and need not involve the teacher" (p. 5). In other words, translanguaging is the act of communication in two mixed languages without planning according to a situation, as opposed to using translanguaging purposely during the Bridge through planned activities, such as recognition of cognates.

Next, in Chapter 2 I will present an overview of the literature on simultaneous bilingual students, their challenges with bilingualism in middle school and high school, and what strategies have been used to help advance biliteracy in two languages. Then, in Chapter 3, the qualitative methodological approach of the case study will be described, which examined how the students respond to the Bridge strategy in humanities classes. 


\section{Chapter 2: Literature Review}

In response to the increasing number of United States school students at all grade levels who have diverse linguistic and cultural backgrounds and needs, often called simultaneous bilinguals, the U.S. school districts are evaluating new strategies to meet their needs. One instructional strategy that seems promising is the Bridge, where students contrast and connect the literacy skills learned in one language to the literacy skills in their other language, which, in turn, seems to make them better in both languages. On the one hand, research has not shown much about the question on how the middle school students respond to the promise of the instructional Bridge strategy. On the other hand, research seems to indicate that student attitude toward their biliteracy also affects their achievement and motivation to learn the home language (Beeman \& Urow, 2013). However, little research has been done on the students' attitudes toward their biliteracy. In particular, there does not seem to be much research conducted on specific strategies designed to help students become bilingual, such as the Bridge strategy used in a humanities dual language/immersion class. The purpose of this study is to explore how simultaneous bilingual middle school students respond to becoming biliterate in Spanish and English as a result of participation in a humanities dual language/immersion class, taught through the instructional strategy the Bridge. My main research question for this study is: How do simultaneous bilingual middle school students respond to becoming biliterate when taught using the Bridge strategy in a humanities dual language/immersion class? 
As described in Chapter 1, there are many factors that contribute to the efforts of students to become bilingual. One factor that has not been explored yet is what the students themselves think of being bilingual. This is important because educators and school officials need to make "informed decisions about the fit between children, program and practices” (O. García \& Kleifgen, 2018, p. 79). Knowing more about how the students respond to the program can help inform and shape future practices.

\section{Introduction}

The following literature review shows what has been done to examine the issues related to biliteracy for simultaneous bilingual middle school students. First, I will explain the rationale behind using the social cognitive theory (Bandura, 1986) to understand the students' responses toward becoming biliterate though the use of the bridging between languages strategy. Next, the review of the literature addresses the following key points: (a) the characteristics of simultaneous bilingual students, (b) the key issues of simultaneous bilinguals, (c) the instructional strategies for simultaneous bilinguals, and (d) the research on the Bridge strategy. Finally, methodological literature that is relevant to the use of a qualitative case study research method is reviewed.

\section{Theoretical Framework: Social Cognitive Theory}

According to Bandura (1986), a theory specifies "the determinants and mechanisms governing the phenomena of interest" (p. xii). Social cognitive theory specifies the mechanisms through which people learn skills, values, behaviors, and how to respond to behavior, either motivationally or regulatory. In other words, people will do something either because they are motivated to do so or because it is dictated by the 
rules, for example, a syllabus for class or the constitution of a country. Hence, in social cognitive theory "learning is conceptualized mainly as a knowledge acquisition through cognitive processing of information" (Bandura, 1986, p. xii). The three key elements in this theory are: environmental, behavioral, and personal. Bandura named the interaction among these three elements as "reciprocal determinism." Reciprocal determinism is the interplay that propels movement from environmental events to behavior and to the personal factors (beliefs). Bandura (as in Davidson and Davidson, 2013) claimed that “one's behavior can also change one's personal characteristics as when we use performance feedback to improve our skills" (Motion picture). Bandura (1986) defined the reciprocal as "the mutual action between causal factors" (p. 23). In other words, the environmental factors, behaviors, and beliefs do not stand alone in learning. Each one affects the other. Behavior brings out social reactions, which, in turn, can alter the course of behavior. The environment, which includes social interactions such as instruction, modeling, and persuasion, can alter the personal beliefs.

Figure 7 illustrates the three elements of Bandura's social cognitive theory. Each element interacts with the other and this interaction is called "reciprocal determination." To understand how students are responding to becoming biliterate, then, I needed to take into account their personal beliefs, their behavior, and the environment in which they are learning, when teaching them in this dual language immersion class. 


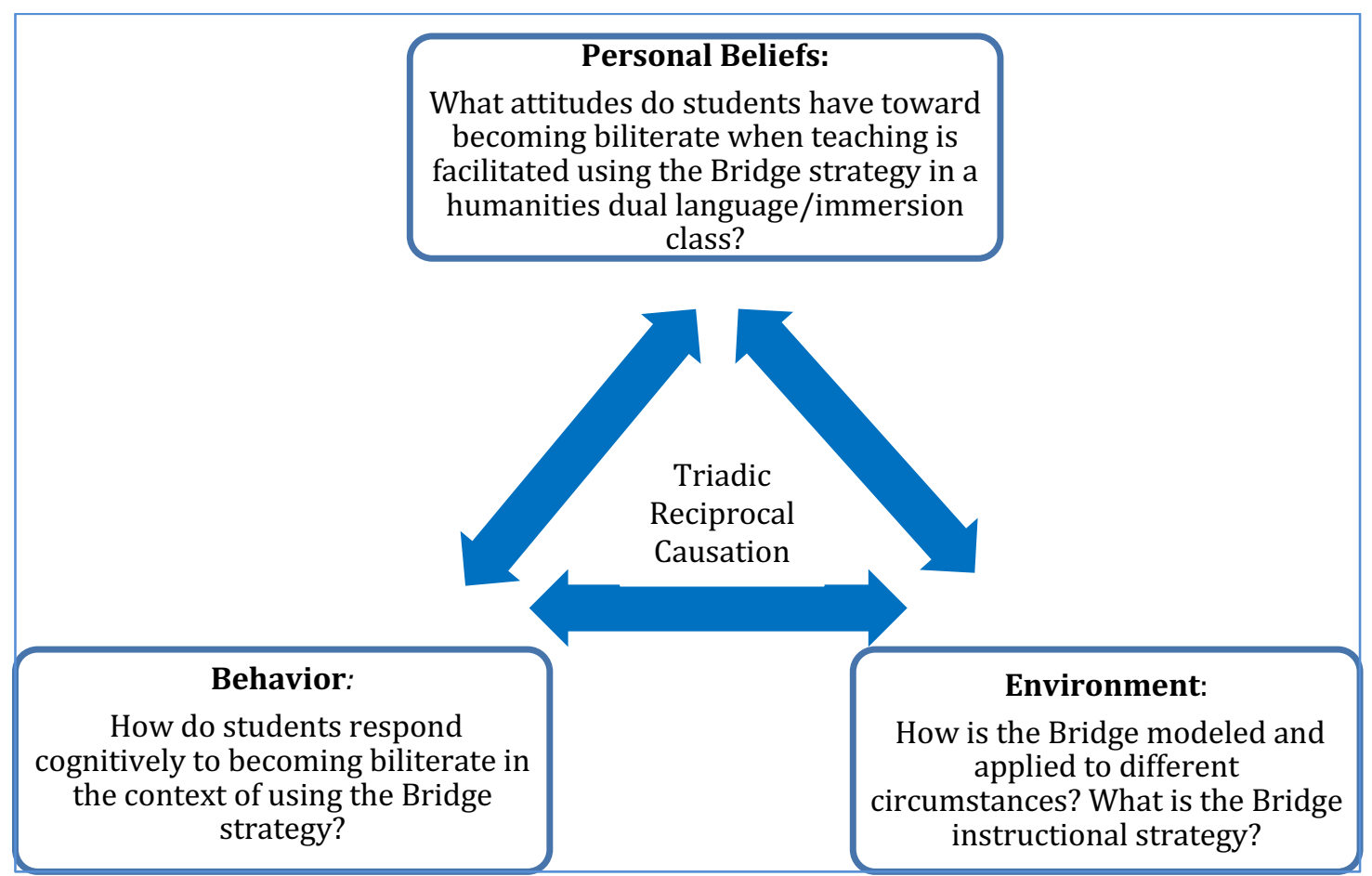

Figure 7. Relations between the three determinants with guiding questions for research. Adapted from Social Foundations of Thought and Action by Bandura (1986, p. 24).

According to Bandura (1986), people learn by observing how other people respond to environmental influences. Transferring this idea to responding to the Bridge strategy in a dual language/immersion humanities class, I included intentional learning into my lessons, which means investing class time in learning as is intended by the Bridge, comparing and making connections between the two languages, and transferring the concepts learned in Spanish to English without re-teaching. According to the Bridge, the simultaneous bilingual middle school students learn concepts in Spanish while the teacher bridges content to English side-by-side. The idea is that the students identify the unique characteristics of the language studied, observe the relation between languages side-by-side, and make the right connection to save time and effort and to advance their biliteracy. This theory also provides a framework for the justification of the 
characteristics needed for a bilingual teacher - a teacher who understands more than one language and culture and how languages are acquired. The last determinant of the model, personal beliefs, can be explored through engaging the student with bridging. It was the purpose of this study to learn how these three determinants influence each other in the application of the responses to bridging with respect to the students' bilingualism.

Bandura's (1986) theoretical framework asserts that the theory can be applied to any human behavior, however, a point of criticism to the theory in this study is that Bandura's work is not specifically addressing the cultural background shared by a simultaneous bilingual student. As it was previously explained, a bilingual person is not equal to two single monolinguals but, instead, a bilingual person is the "new normal" (Escamilla et al., 2014, p. xi).

\section{Review of the Research Literature}

In my review of research literature, I look at the characteristics of simultaneous bilinguals, key issues of simultaneous bilinguals, the typical instructional strategies that are used to help these students become bilingual, and, in particular, at the research on the Bridge strategy, which is a newer strategy for fostering bilingualism. Table 1 summarizes the literature that will be discussed later in this chapter. 
Table 1

Literature Review

\begin{tabular}{|c|c|c|}
\hline Key Issues & Instructional Strategies & Emergent Bilinguals Attitudes \\
\hline $\begin{array}{ll}\text { - } & \text { Vocabulary } \\
\text { - } & \text { Reading Comprehension } \\
\text { - Written Production }\end{array}$ & $\begin{array}{l}\text { - Translanguaging } \\
\text { - Cognates } \\
\text { - The Bridge } \\
\text { - Code-switching } \\
\text { - } \text { One language to explain } \\
\text { - The other } \\
\text { - Transfer }\end{array}$ & - Attitude and Motivation \\
\hline
\end{tabular}

The characteristics of simultaneous bilinguals. The number of students that spoke a language other than English in U.S. public schools in 2014-2015 was, in general, higher than in previous years. The majority of the speakers of other languages were in $\mathrm{K}-5$ grades (16.7\% of which were in kindergarten), compared to $9.8 \%$ in the sixth grade and $6.5 \%$ in the eighth grade (McFarland et al., 2017). These percentages show the importance of strengthening bilingual education programs at the secondary level. Merril Swain (as cited in Escamilla et al. 2014) had already mentioned that for these simultaneous bilingual students "bilingualism (and not English or Spanish) is their first language" (p. xi). According to Escamilla et al. (2014), these students are "the new normal" (p. xi), as they are acquiring two or more languages in their homes and in their community at the same time.

Woodrich and Fan (2017) and Gibson (2016) pointed out that English language learners are behind in vocabulary and academic content in comparison to their monolingual peers. According to the Migration Policy Institute (Sanchez, 2017), 62\% of English Language Learners were born in the United States. This illustrates that, although English language learners started learning English from kindergarten on, they have not 
attained the same academic level as their peers because teaching practices are not adapted to the needs of simultaneous bilinguals (Woodrich \& Fan, 2017).

The key issues of simultaneous bilinguals. To understand simultaneous bilinguals better according to the purpose of my study, I explored what the existing research says about the issues that challenge bilingual students, especially, their vocabulary needs, reading comprehension, and written production.

Vocabulary needs. Research indicates (Carlo et al., 2004) that one of the greatest challenges for simultaneous bilinguals is the development of an adequate vocabulary in both languages. Not having a sufficient vocabulary affects their writing and reading skills. Carlo et al. (2004) studied various techniques for teaching vocabulary to English language learners and English-only students in a combined classroom using a "quasiexperimental design" method. There were two groups of students—one was the comparison group and the other received intervention treatment to see if it would boost its participants' vocabulary knowledge. The purpose of the study was to explore the ways in which vocabulary and word-learning strategies can be taught to English language learners and English-only fifth grade students more effectively. Carlo et al. found that, through an intervention that had exposed the students to the meaning of words in their native language in varying contexts and through the dimensions of spelling, pronunciation, morphology, and syntax, the vocabulary knowledge was boosted for both English language learners and English-only students. This result is important for my study because it shows that traditional techniques used to teach vocabulary to EnglishOnly students can also benefit English-language-learner students. The study could have 
benefited from further exploring what additional differences the particular bridging techniques made that were employed for English language learner students and how being able to leverage the students' knowledge of Spanish for accelerated learning must have made them feel.

Harmon, Antuna, Juarez, Wood, and Vintinner (2018) studied 25 high school social studies teachers who used a qualitative method. The purpose of this study was to focus on the understanding of and perspectives about vocabulary acquisition and instruction. They found that student-differentiated instruction benefited not only English Language Learner students but all students. This is important for my study because it indicates that student-differentiation in bridging should increase its effectiveness.

Reading comprehension. The second issue for bilinguals is reading comprehension. Aukerman, Schuldt, Aiello, and Martin (2017) studied reading comprehension among second grade students using a descriptive naturalistic method. The purpose of their study was to learn how simultaneous bilinguals can better explore the meaning of a text in a collaborative manner that the authors call "intercomprehending." They found that simultaneous bilinguals can more effectively explore the meaning of a text by collaboratively "building on what they know." This is important for my study because, in my opinion, it shows that the collective aspect - the way students feel about their bilingualism - is important to explore.

Garcia and Godina (2017) studied six fourth grade simultaneous bilinguals in a qualitative study informed by social literacy and holistic bilingual perspective methods. The purpose of their study was to examine how these students created meaning when 
reading narrative and expository texts. They found that simultaneous bilinguals used a variety of bilingual strategies, such as: translanguaging, code-mixing, the use of cognates, the use of one language to explain what they read in the other, transference, and more similar strategies that leverage more than one language. There is again a certain significance, because it allows for an exploration of how the students' bridging skills evolve from primary school to middle school.

Symons, Palincsar, and Schleppegrell (2017) studied 10 fourth grade simultaneous bilinguals using a qualitative, descriptive case study. The purpose of this study was to illustrate how simultaneous bilinguals "use the metalanguage and the consciousness it engenders" (p. 102) to create meaning for science texts. They hypothesized that "functional grammar helps students recognize how a text means what it does" (p. 102). This is also an interesting aspect, because it seems that one piece of the reading comprehension challenge is the use of functional grammar techniques.

Written production. The following studies focused on how the students use their heritage languages to acquire skills on grammar and composition in English. Smith, Pacheco, and de Almeida (2017) studied three eighth grade students, through the integrated translanguaging and social semiotics theoretical frameworks, using a comparative case study. The purpose of this study was to understand how multilingual students compose across multiple languages—-Spanish, Bahdini, and Vietnamese—and modalities, through a "Scaffold Digital Writer's Workshop" (p. 10). They found that the students used their heritage languages during the composing process in different ways and that, in the end, they felt that they were more fluent with digital tools as well as more 
comfortable using their heritage languages. This is important for my study because it shows how bridging from one language helps students compose in another language, which, in turn, makes them better in their first language.

Woodrich and Fan (2017) studied 97 eighth grade students using the qualitative method. The purpose of this study was to examine how online writing tools can be used to encourage participation of students with different English language abilities. They found that online writing tools are beneficial for increasing the student composition production in different modalities. This must be taken into consideration because it shows that bridging techniques which leverage online writing tools could be particularly effective.

The instructional strategies. In this section, I focus on the different instructional strategies that teachers are using to support their students' language acquisition. Dressler, Carlo, Snow, August, and White (2011) studied the ways in which Spanish speakers, who are English language learners, infer meaning from text through cognates using a qualitative research. The purpose of this study was to explore how the English language learners' knowledge of Spanish helped them grasp the meaning of Spanish-English cognates. They found that the students needed to be taught the "cognate strategy." They did not intuitively apply it. This should not be disregarded, because it implies that bridging strategies may not come intuitively to all students.

O’Connor, Beach, Sanchez, Bocian, and Flynn (2015) studied 38 eighth grade students (50\% English language learners and 50\% special education students), who were reading four to six years behind grade level, using design-based research. The purpose of 
this study was to improve instructional methods to advance the reading of students, who are behind their grade-level skills, in collaboration with small groups of teachers. They found that the students in the intervention group improved their vocabulary and comprehension and their design-based approach yielded three instructional cycles. This research is important for my study because it shows how I can combine a variety of bridging techniques into instructional cycles, through a method such as a design-based research approach, for the purpose of evaluating the students' responses to bridging.

The Bridge as a strategy to promote biliteracy. The Bridge (Beeman \& Urow, 2013) promotes biliteracy by allowing the teachers and students to contrast and make connections between English and Spanish in a unit of study. Bridging between languages brings the two languages to the same level of importance in the educational system.

Jiménez, García, and Pearson (1995) studied the abilities of three sixth grade students using the qualitative method. The purpose of their study was to understand the metacognitive strategies of Latino students. They found that "explicit knowledge of the relationship between Spanish and English can facilitate bilingual students' reading comprehension" (p. 67). This must be included in my study, because it is another example of how bridging is able to make a difference in the students' learning. Furthermore, I believe that it helps the students realize the advantages of being bilingual.

As mentioned in Chapter 1, for Beeman and Urow (2013), the Bridge strategy is a language strategy that a learner would use to compare and connect skills learned in one language to the other language without having to study the same skill in the other language again. Strategies like the Bridge seem to have helped advance the biliteracy of 
simultaneous bilingual students in elementary grades (Beeman \& Urow, 2013). The teacher plans how to employ the Bridge strategy during a lesson. Once language and content objectives have been met, the students identify the similarities and differences between languages. This moment, when the teacher and the students compare the languages and make connections is called the Bridge. For example, Table 2 shows how a humanities vocabulary lesson for a narrative text relates to the Bridge. Students first learn about the characteristics of a narrative text and then compare the vocabulary for both, content and text characteristics.

\section{Table 2}

The Bridge in a Narrative Text Lesson: Writing About the Influence of Our Personal Stories

\begin{tabular}{|c|c|}
\hline Español & English \\
\hline Estructura del relato & Plot Structure \\
planteamiento & exposition \\
desarrollo & rising action \\
momento crucial & climax \\
desenlace & falling action/resolution \\
metáfora & metaphor \\
hipérbole & hyperbole \\
punto y coma & semi-colon \\
de la misma manera & by comparison \\
\hline
\end{tabular}

Another study in support of translanguaging was conducted by Daniel and Pacheco (2016). They studied four secondary school students, two eighth grade and two 
twelfth grade students, respectively, using the qualitative method. The purpose of their study was to understand how speakers of languages other than English "draw from linguistic resources to make sense of their worlds and how they perceive their language use across contexts" (p. 654). They found that the students' translanguaging strategy supported the students' academic development, that it provided value to their languages other than English in the school context, and that the students "use multiple languages in their thoughts, writing, and speech" (p. 660). This is important for my study because the authors show that bridging happens in multiple dimensions - thinking, writing, and speaking.

\section{Review of the Methodological Literature}

In this section I will review the methodological literature that I used in my study. First, I will discuss the selection of research methods, then give a summary of the research literature, and finally, point out the application to my study.

Selection of research methods. A qualitative researcher, according to Merriam (2009), is interested in how people construct meaning, interpret their experience, and attribute meaning to their lives. In this study, I explored how simultaneous bilingual middle school students respond to their bilingualism as a result of participation in the Bridge strategy between two languages in a humanities dual language/immersion class. The research question for this study is: How do simultaneous bilingual middle school students respond to becoming biliterate when taught using the Bridge strategy in a humanities dual language/immersion class? Based on the purpose and research question of this study, the best orientation for the study is qualitative research. Merriam (2009) 
concluded that "qualitative researchers are interested in understanding the meaning people have constructed" (p. 13). One of the recommendations of O. García and Kleifgen (2018) is that more research should focus on the person (teacher and student) when looking at pedagogies and practices" (p. 178). In this study, I explored how the students respond to their bilingualism as a result of the Bridge strategy. The focus of this study was on the students and their interpretation of their bilingualism in response to "pedagogies and practices," in other words, to the Bridge strategy (O. García \& Kleifgen, 2018, p. 178).

Furthermore, a qualitative research approach fits with the social cognitive theory (Bandura, 1986) as the framework through which the students' responses were analyzed. I argue that, for me to understand the best pedagogies and practices focused on the person, the qualitative research approach supports my purpose and questions.

The coding of data provided an insight into the best approaches to support simultaneous bilinguals to advance their biliteracy, as well as to consider their belief, attitudes, and the influence of the environment on the production of their own environment and recognition of their self-efficacy. In Chapter 3, I will further expand on the methodology employed.

\section{Summary of the Research Literature and Its Applications to This Study}

Most research that focuses on simultaneous bilinguals is geared towards the linguistic components of the language and assessment. García and Kleifgen (2018) recommended that more studies are needed that focus on "the students themselves and 
the teachers' pedagogies and practices" (p. 178). My study adds to the body of research by asking the students how they feel, think, and react towards their bilingualism.

Moreover, Bialystok \& Hakuta (1994) acknowledge that when students see the dual language / immersion programs as something positive, it motivates them to do better and as a result the achievement is higher allowing for a more positive learning experience. Focusing on students' experience may impact graduation rates and academic achievement. In the following chapter, I will explain the method used to study students' responses to becoming biliterate. 


\section{Chapter 3: Method}

In this chapter, I will describe the qualitative method I used for my research. I will explain the boundaries of the case study, the participants, the instruments, the procedures, and the role of the researcher.

\section{Introduction}

According to the U.S. Department of Education, the Hispanic student population accounts for $26.4 \%$ of speakers of other languages in U.S. schools (McFarland et al., 2017). The research problem is that school districts are introducing new ways to address their needs and we do not know much about how effective these are yet. Nevertheless, one of the factors that seem to affect student development of biliteracy is their own attitude and behavior toward becoming bilingual. Garcia and Kleifgen (2018) suggested that more studies are needed on the students themselves. I was interested in learning more about how simultaneous bilingual middle school students respond to bilingual instruction in my dual language/immersion classroom. The purpose of this study is to explore how simultaneous bilingual middle school students respond to becoming biliterate in Spanish and English as a result of participation in a humanities dual language/immersion class, taught through the instructional strategy the Bridge.

How do simultaneous bilingual middle school students respond to becoming biliterate when taught using the Bridge strategy in a humanities dual language/immersion class? This chapter discusses the qualitative methodology used for a collective case study of simultaneous bilingual middle school students using rubrics to explore the students' 
views of the Bridge strategy between two languages in a humanities dual language/immersion class. In addition, I explain the setup of my study: participant recruitment, data collection instruments, procedures to conduct the study, the role of the researcher, and, finally, the data analysis procedures.

\section{Research Method}

Because the nature of my research question is related to gaining understanding, I decided to use qualitative research methods. Maxwell (2013) suggested that several of the intellectual goals of qualitative research are:

(1) Understanding the meaning, for participants in the study, of the events, situations, experiences, and actions they're involved with or engage in....

(2) Understanding the context within which the participants act, and the influence that this context has on their actions....

(3) Identifying unanticipated phenomena and influences in generating new, "grounded" theories about the latter....

(4) Understanding the process in which actions take place. (pp. 30-31)

Therefore, given that I am using Bandura for my theoretical framework, Maxwell's four tenets of qualitative research align with my research methods. I used qualitative research to understand how my students respond to the classroom lessons in the dual language classroom context. In addition, the variety of qualitative methods I used helped me identify any "unanticipated phenomena and influences" and also contributed to a deeper understanding of how the students respond to the Bridge strategy as a process. I also chose this design because qualitative research, as defined by Creswell (1998), is "an inquiry process of understanding based on distinct methodological 
traditions of inquiry that explore a social or human problem" (p. 15). I sought to listen to my students' experiences.

Ultimately, the result was a case study. Yin (2016) defined a "case study as an empirical inquiry that: (a) investigates a contemporary phenomenon within its real-life context, when (b) the boundaries between phenomenon and context are not clearly evident, and in which (c) multiple sources of evidence are used" (p. 23). My study took place in my classroom, a real-life context. Learning to become bilingual is a complex process (Beeman \& Urow, 2013). There are a variety of data sources that I utilized to understand how my students are responding to becoming bilingual in the context of the Bridge strategy. These data enriched my understanding of the case study conducted in my classroom.

\section{Boundaries of the Case Study}

A case study has boundaries; therefore, the boundaries of my case study are in the Western United States, in a single middle-school, in one classroom, only sixth-grade students, and only in Spanish and English. As mentioned before, other possible dual language/immersion programs are Chinese, French, German, Japanese, Persian, Russian, Somali, Ukrainian, and Vietnamese. Figure 8 illustrates the boundaries of the case study. 


\section{Boundaries of the Case Study}

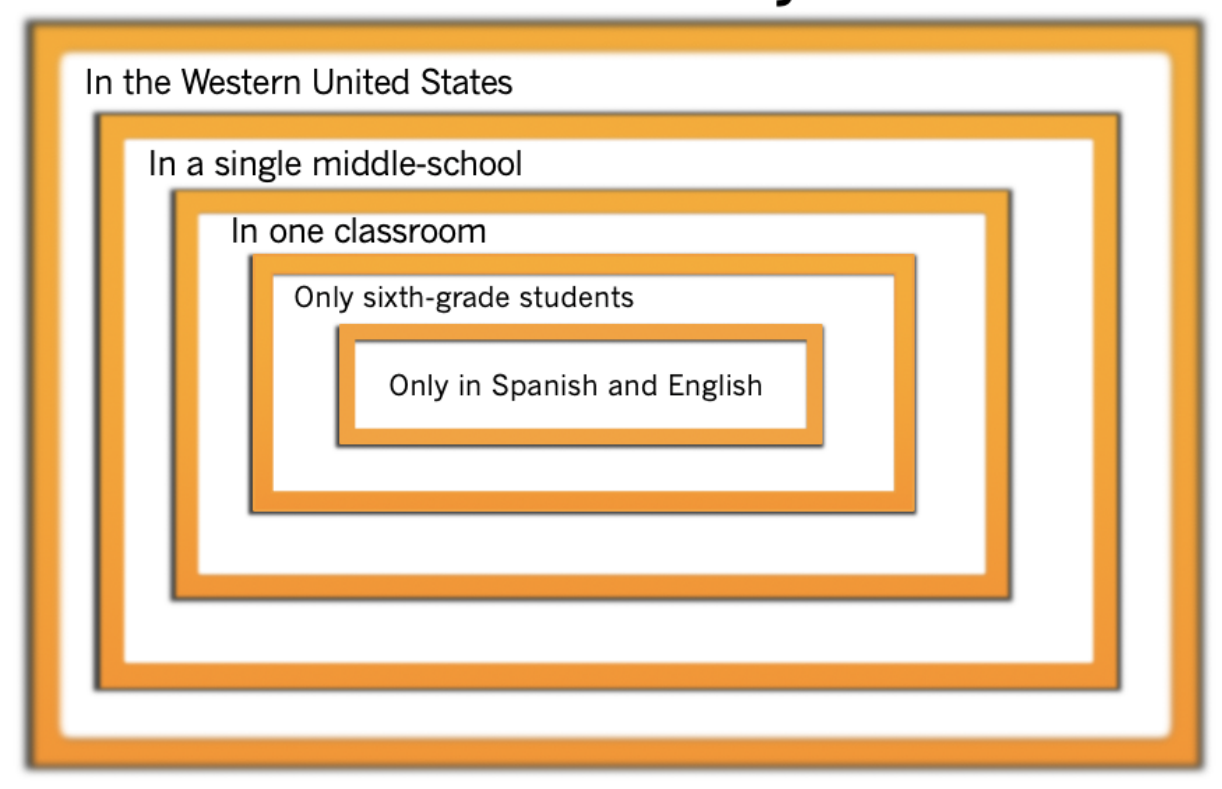

Figure 8. Boundaries of the case study.

\section{Participants}

The focus was on 12 sixth-grade simultaneous bilingual middle school students who have had at least three years of bilingual education. There were other students in my class who have not had any prior bilingual education. To participate in the Bridge, the students needed to have basic literacy skills in both languages. Most students who have received English language services for a minimum of three years have a fundamental knowledge of the structure of both English and Spanish. The students who were not literate in one or the other language did not participate in this study. The dual language program has an average of 65 students in a total of three humanities classrooms (during the 2017-2018 school year there were 12, 17, and 25 students, respectively, and during the 2018-2019 school year there were 34, 23, and 23 students, respectively). Of these, the 
majority has had at least three years of bilingual education. I recruited the students through a letter to the students in Spanish and English (see Appendices C and D), a letter to the parents also provided in English and Spanish (see Appendices A and B), accompanied by the provision of information about the project on back-to-school night (see Table 3).

Table 3

\section{Criteria for Participation}

Criteria for Participation in Research Study

$\square \quad$ Sixth grade simultaneous bilingual middle school student.

$\square \quad$ At least 3 years of bilingual education.

$\square \quad$ Student in my humanities classes.

$\square \quad$ Student willing to participate in study.

$\square \quad$ Parent consent form signed.

The context was a middle school humanities dual language/immersion class framed by the Middle Years Programme derived from the International Baccalaureate. In addition, there was also a school-wide program called Advancement Via Individual Determination in place, which centers on the strategies teachers use to deliver content. The teachers in the Advancement Via Individual Determination Program shared many classroom practices. The study took place in a middle school on the U.S. West Coast. Classroom units of study followed the state standards for English Language Arts and 
Social Studies and aligned with the school district goals that meet the humanities frame of the Middle Years Programme. The humanities content was facilitated through the inquiry-based approach of Middle Years Programme using Advancement Via Individual Determination strategies in Spanish. Consequently, the program provided opportunities for cross-linguistic practices such as: translanguaging, code-mixing, cognates, employing one language to explain the other, Total Physical Response, role-play, and partner share. This class met all year long for 80 minutes every day. The school district has maintained a commitment to the dual language program from kindergarten to grade 12 . Ultimately, the district goal is for the students to be literate in at least two languages by the time of high school graduation so that they may attain the Oregon Seal of Biliteracy (Oregon Department of Education, 2016b).

\section{Data Collection Instruments}

In the section below, I will describe the instruments I used to collect the data necessary to inform my case study on how bilingual middle school students respond to their bilingualism as a result of participation in the Bridge strategy between two languages in a humanities dual language/immersion class. The instruments in this case study were student scores on a series of Bridge classroom activities, a survey using a response on a verbal scale, a draw-a-simultaneous-bilingual-student drawing, an individual student narrative description of the draw-a-simultaneous-bilingual student activity, transcriptions from the focus group, and my own observations. Table 4 illustrates the data collected from each instrument. 
Table 4

\section{Collection of Data by Instrument}

How do simultaneous bilingual middle school students respond to becoming biliterate when taught using the Bridge strategy in a humanities dual language/immersion class?

\begin{tabular}{|c|c|c|c|c|c|}
\hline & $\begin{array}{l}\text { the Bridge } \\
\text { Lessons \& } \\
\text { Activities }\end{array}$ & Survey & $\begin{array}{c}\text { Draw-a- } \\
\text { Bilingual } \\
\text { Student }\end{array}$ & $\begin{array}{l}\text { Free- } \\
\text { Narrative }\end{array}$ & $\begin{array}{l}\text { Focus } \\
\text { Group }\end{array}$ \\
\hline $\begin{array}{l}\text { What do student achievement scores tell } \\
\text { me about developing biliteracy using the } \\
\text { Bridge strategy? }\end{array}$ & $\sqrt{ }$ & & & & \\
\hline $\begin{array}{l}\text { What attitudes do students have toward } \\
\text { becoming biliterate? }\end{array}$ & & $\checkmark$ & $\sqrt{ }$ & $\checkmark$ & $\sqrt{ }$ \\
\hline $\begin{array}{l}\text { How do students transfer literacy skills } \\
\text { learned through the Bridge to new } \\
\text { situations in the other language? }\end{array}$ & & $\sqrt{ }$ & $\sqrt{ }$ & $\sqrt{ }$ & $\sqrt{ }$ \\
\hline $\begin{array}{l}\text { How do students respond to becoming } \\
\text { biliterate in the context of using the } \\
\text { Bridge strategy? }\end{array}$ & & $\checkmark$ & & & $\checkmark$ \\
\hline
\end{tabular}

Survey. According to Krathwohl (2009), a survey allows for the collection of data from a broader "sample of population" (p. 567). Surveys are intended to document the reactions of the population to certain topic. On surveys, Krathwohl (2009) added that the survey provides information according to the population that provides it. Because a survey is based in "constructs" (p. 568), is important to consider carefully the purpose of the survey to avoid compromising the information. Krathwohl (2009) mentioned that some of the advantages of an Internet-based survey are freedom of space and fast 
delivery to participants. Some of the disadvantages are the lack of access to a broadband Internet connection, typing difficulty, and the option not to respond.

The survey method, in comparison to a focus group method, provides the participants with the choice to stay anonymous and express their thoughts freely without any censorship or intimacy from those more outspoken in the group. The participants can take their time to think about their answers and change them as they please.

My goal for the survey was to collect specific data on students' self-assessment of understanding of instructional strategies used in the classroom to advance biliteracy as well as their reasons to pursue what the adults around them wish for them regarding their biliterate education. Adapted from Gardner and Lambert's (1972) research on attitudes and motivations to learn a second language, the survey questions were carefully worded to avoid bias, to reflect the educated bilingual students in my classroom, and to make it fit a "response on a verbal scale" (Krathwohl, 2009, p. 576) type in the format of a Likert scale from different levels of agreement. The survey provided data to triangulate information and compare it with the information gathered from the students' biliteracy scores in the three dimensions of a writing assignment, draw-a-simultaneous-bilingual student activity, narrative description of the drawing, and a focus group discussion.

Focus group. Yin (2016) defined a focus group as a form of data collection whereby the researcher convenes a small group of people having similar attributes, experiences, or "focus" and leads the group in a nondirective manner. The objective is to surface the perspectives of the people in the group with as minimal influence by the researcher as possible (p. 333). 
Glesne (2016), Krathwohl (2009), and Yin (2016) agreed that a significant advantage of a focus group is that a discussion in a small group can bring to the fore how people feel, especially when children are supposed to talk about their experience. Yin (2016) cautioned that, when studying children, the researcher should "avoid putting words into the children's mouth" (p. 53). Glesne (2016) and Krathwohl (2009) quoted Morgan $(1997,2002)$ on the characteristics of a focus group, such as size, meeting, seating arrangement, allotted time, and the number of questions. Krathwohl (2009) mentioned some of the problems with focus groups, such as arranging meeting times and places, as well as recruiting "the right mix of people - educational homogeneity" (p. 305). In addition, Krathwohl (2009) cautioned that dominant speakers in the focus group could also censor others from speaking.

I chose this method for the study because, as Yin (2016) mentioned, studying children is better with their peers than in a one-on-one researcher-student interview setting, because it is a setting in which they can co-construct meaning and help each other discover their feelings and responses about being bilingual and their responses to the Bridge. As Glesne (2016) pointed out, my participants were already “classmates” (p. 44) and already knew each other. Therefore, it was easier for them to talk amongst themselves than with strangers or the researcher. The focus group met on December 17, 2018 after regular school hours from 3:50 pm to 5:00 pm, in classroom B10 at Éxito Middle School, for the dual language humanities class. The focus group, also participants, met the criteria mentioned in the participant's recruitment section. 
My goal for the focus group was to gather more information from the students through an open and collaborative dialogue about three major points. First, about their personal view of a bilingual person. Second, about their understanding of how the environment influences their bilingualism. And third, about how their personality transforms when they understand how the Bridge improves their biliteracy. I take into consideration that at this age, children have to do what adults say. However, with dual language immersion programs, students may have more weight in the decision to belong to the program than just in general education.

Draw-a-bilingual student activity. The draw-a-bilingual student method is inspired by the draw-a-man test for intelligence develop by Goodenough in 1926 and the draw-a-scientist test developed by Mead and Metraux in 1957 (as cited in Chambers, 1983). Their goal was to learn how the students imagine a scientist from a young age to high school at different times. They found that, because the test does not rely on verbal communication, young participants, older participants, and those from diverse linguistic backgrounds could all communicate a response. Chambers (1983) concluded that this instrument identifies the attitudes in response to the prompt instead of "measuring" (p. 265). Therefore, a hypothesis cannot be drawn.

I chose this method to explore the participants' perceptions of a bilingual person. It is a free drawing in which I was asking the students simply to draw-a-bilingual student. Chamber (1983) found that "the socio-economic differences, sex differences, intelligence differences, and French/English differences" (p. 262) influenced the way in which the participants drew the scientist. Besides, depending on the life experiences of his 
participants, alternative illustrations were analyzed that gave further insight into the meaning behind a scientist.

By employing this method, my aim was to obtain a broader understanding of how the participants project themselves and other bilinguals as well as to allow for an opportunity for all participants to express themselves in a variety of ways. There might have been some who were more artistic than verbal and this method provided an opportunity for them also. It also supports the triangulation of data collection method for a comparison and analysis from a holistic point of view.

Free-narrative. In addition to the draw-a-bilingual student, I asked the students to add a free-narrative description of their drawing. Free narrative is defined by Powell and Snow (2007) as an organized story that allows an outsider to understand the events that happened. A story contains all the standard elements: a setting, rising action, central action, motivations, responses or falling action, and consequences or resolution. My goal with the free-narrative was to gain an insight into the students' interpretation of their own drawing. This was intended to utilize the students' words for the analysis of the drawing as well as to provide an opportunity for the students to label the elements of their drawing.

\section{Activities for the Bridge}

Planning the activities for the Bridge involved the planning of a complete unit of study. Table 5 shows that the format of this strategy is a three-part planning process: Before the Bridge, the Bridge, and after the Bridge.

- Before the Bridge, the content of the study unit was taught in Spanish. 
- The Bridge was the moment in which the teacher intentionally prompts students to compare languages and draw conclusions about the similarities and differences.

- After the Bridge was completed through a variety of cross-linguistic activities, an extension activity was conducted in English, studying same language content with authentic materials in a shorter period of time.

Table 5

Format of the Bridge

\begin{tabular}{|c|c|c|}
\hline Before the Bridge & The Bridge & After the Bridge \\
\hline $\begin{array}{l}\text { Tap background } \\
\text { knowledge } \\
\text { Check reading } \\
\text { comprehension } \\
\text { Refine writing skills } \\
\text { Engage in vocabulary } \\
\text { study } \\
\text { Direct students to write } \\
\text { an essay in first } \\
\text { language-Spanish }\end{array}$ & $\begin{array}{l}\text { Show students how to } \\
\text { transfer skills between } \\
\text { Spanish and English } \\
\text { Identify differences and } \\
\text { similarities } \\
\text { Transfer language skills to } \\
\text { the other language }\end{array}$ & $\begin{array}{l}\text { Direct students to write an } \\
\text { essay in the second language- } \\
\text { English } \\
\text { Assess their writing skills and } \\
\text { compare Spanish and English } \\
\text { essays for transfer of skills }\end{array}$ \\
\hline
\end{tabular}

I intentionally selected activities for the Bridge to address the activation of previous knowledge, reading, writing, listening, and speaking skills. Beeman and Urow (2013) suggested some activities for the Bridge strategy. For my study, I integrated some activities that they suggested for the advancement of biliteracy that also aligned with the Advancement Via Individual Determination strategies and the Middle-Years Programme inquiry model. These activities were "word sort and sentence" (p. 83), "formal and informal language anchor charts" (p. 85), "read aloud, talk to your partner, and sentence prompts" (p. 92), "dialogue journals" (p. 106), “content-area journals" (p. 107), "word wall and anchor charts in Spanish" (p. 122) and English, and "The Dictado" (p. 126). My goal with these activities was to provide the time in the class itself for the students to 
recognize the integration of the Bridge strategy, allowing them to translanguage, codemix, identify cognates, and to employ one language to explain their reading comprehension in the other language. In addition, I wanted to provide the time for the students to reflect on how the Bridge helps them advance their biliteracy.

This section described the instruments and why they were used in the study to collect the data. In the next section, the procedures followed to collect the data for the study are described.

\section{Procedures}

This section describes the order in which the study was conducted. The procedures used to recruit the participants and the steps to collect and protect their data for the duration of the study are also explained in more detail here.

Recruitment of participants. As previously stated, the participants in this study had at least three years of bilingual education and were enrolled in the middle school dual language/immersion program. To recruit participants, both parent and student consent forms were provided. In addition, I provided additional information during the Back-toSchool night event in fall. I collected the data for the study during the humanities classes in my classroom over an eight-week period. Focus group interviews took place in the classroom after students had utilized the Bridge strategy in class. Focus group discussions were recorded and transcribed in written form for the sake of analysis. The survey was completed in the classroom during the study timeframe.

Informed consent. Seidman (2013) explained the information that needs to be on the consent form. The purpose of the consent form is to protect the study participants 
from any misuse of information by the researcher. While classroom activities, summative assessments, a survey, focus groups discussions, drawings, and narratives do not possess a high-risk profile, they are nevertheless "not risk free" (p. 63). Seidman (2013) explained that requesting information from participants may activate emotions that may cause discomfort, which is why it is important that the participants have the right to participate freely and voluntarily and to be fully informed of the purpose of the study and the data that will be collected. The adapted requirements by Seidman (2013) were included in the "Parent \& Guardian Consent Form" that was distributed to parents in both English and Spanish. A copy of this form can be found in Appendices E and F. These forms were distributed upon receiving the Institutional Review Boards approval during Back-to School night and were sent electronically to ensure that all parents, students, and school administration members received the information about the study I was conducting.

Maintaining data collected. The participants' identities were kept confidential through the use of pseudonyms in the study. The data from the study was locked in a file cabinet and electronic information is password protected. Upon completion of the study, all data collected will be stored for a three-year period and then destroyed.

Steps to gather data. In this section, I describe the order in which I conducted my study. An overview can be seen in Figure 9. I began with the unit of study in which I used the Bridge strategy in the class. Next, a survey was distributed to the students. Subsequently, I asked the students to draw-a-bilingual student and to free-write a narrative for the drawing. Finally, a focus group was conducted. 


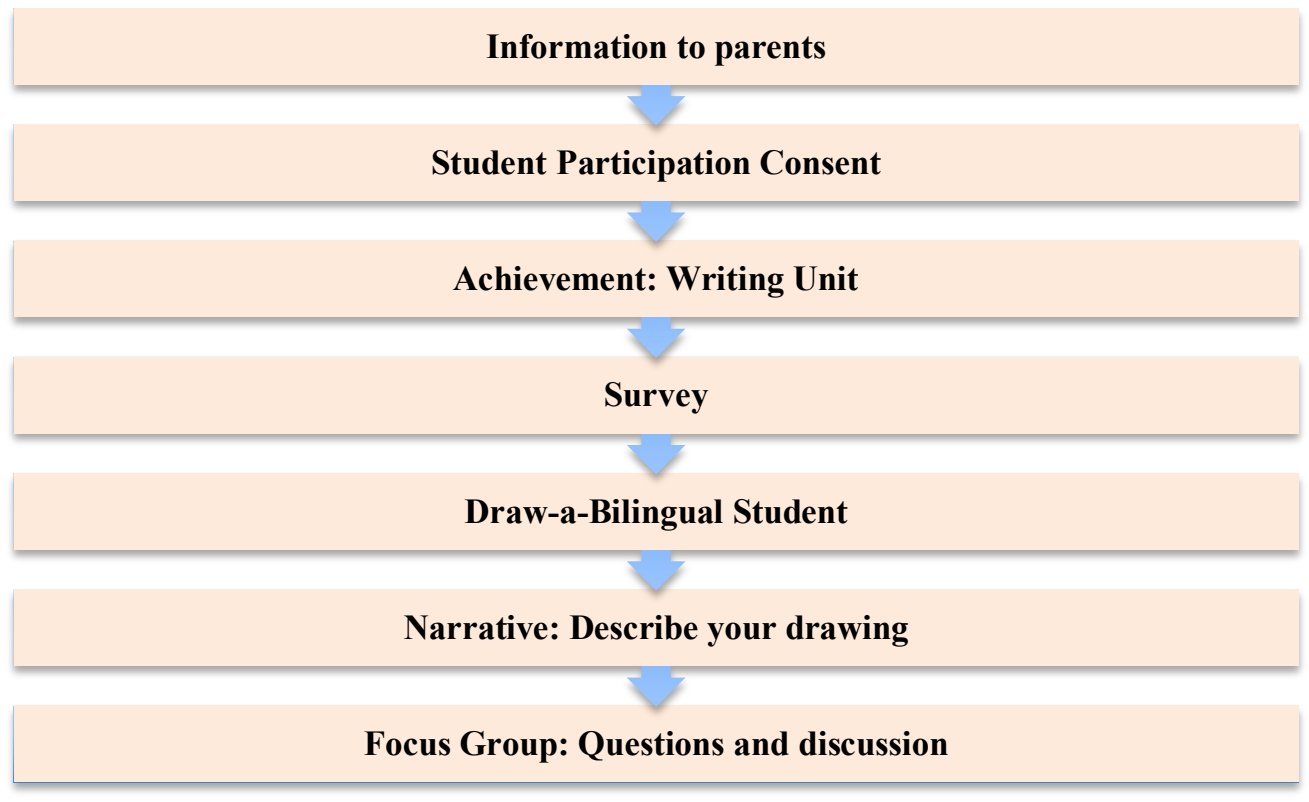

Figure 9. Study procedures that include the type of data collected and the order in which it was collected.

Achievement: Writing unit. The students were guided to write a narrative story in Spanish - see lesson plan in Appendix G. They read a mentor text called Cajas de Cartón by Jiménez (2000) and received all instructions about how to write a personal narrative in Spanish. Once they completed the reading and writing in Spanish, I asked the students to use what they had learned in Spanish to write a personal narrative in English. To accomplish the English writing, I strategically guided the students to observe and identify the similarities and differences between Spanish and English to connect the content to English. After the Bridge the students read Iqbal by D'Adamo (2003). The recognition of cognates, translanguaging, code-mixing, and use of one language to explain the other was encouraged. Students learned figurative language, transitions, character development, setting, and conventions in both languages. A rubric supported the student writing 
process and learning (see Appendix H). Furthermore, the students read Iqbal by D’Adamo (2003) as a mentor text in English.

The students had a progression rubric indicating what they should have been able to do in fifth grade and the current sixth grade expectations. The Bridge allowed for a progression of their literacy skills based on state standards. For English, it was a combination of English Language Development state standards with English Language Arts state standards. For Spanish, it followed the Spanish Language Development Standards. In addition, I framed the language standards through the units of study in Personal Narrative Writing, Grade 6 by Calkins, Fell, and Marron (2014), and I used Advancement Via Individual Determination instructional practices and delivery strategies to provide support and scaffold the writing of my students.

These activities lasted for approximately eight weeks. The students showed interest in both mentor texts in which the main characters are young boys and in how their stories are presented as personal narratives. As we read the stories, the students and I engaged in discussions on the writing craft and on how the audience gets interested in such stories. As we read, the students worked on their own personal narrative stories, writing, revising, and editing.

Survey. The survey was distributed after the students had turned in achievement evidence on personal narratives. They reflected on how the Bridge strategy is intended to advance their literacy skills in the two languages. A quantitative analysis of the scores of the responses on a verbal scale survey was taken. I simply looked at the means across the 
scores to analyze a student's bilingualism and skill transfer from Spanish to English not to do a statistical test on the scores. The survey questions are in Appendix I.

Draw-a-bilingual student. All students in my sixth-grade classes participated in this activity. I asked the students to draw what they thought was the visual representation of a bilingual student. The creative, talented, and artistic students took about 20 minutes to complete their drawing in comparison to the ones who used stick figures for their visual representations. Some added dialogues, and additional artifacts are further discussed in the results section. Some students wondered for some time about how could they draw a bilingual student, in the sense that they just thought of a person like them. They told me that such a person can be anybody from their choice reading books or it can be anybody in the world. I acknowledged all of their comments and asked them to assign an image to all of their verbal labels. This activity took about 20 minutes.

Narrative: Describe your drawing. The students took 10-15 minutes to complete this activity. While the class promotes writing, because the study took place at the beginning of the year, the students' writing stamina was not developed yet. The students understood that they had to describe their drawing by labeling their drawing to enable a comparison between what one can see in their drawing and what written information they additionally provide.

Focus group. The students stayed after school on Monday, December 17th, 2018 for an additional 1.5 hours to participate in a focus group - see Appendix L for protocol and questions. During this time, we had a snack and set the equipment to record their conversation with Mrs. JoAnna Flores, the teacher on special assignment for the dual 
language program in the Productividad School District. During this time, I did not participate in the conversation to allow the students more freedom to share their feelings about being a bilingual student and their perception of literacy acquisition in both languages in our dual language humanities classes. Their conversation lasted approximately about 80 minutes, which was more than expected. It was evident that they had enjoyed the conversation and it was an interesting conversation for both them and Mrs. Flores. At the end of the discussion, Mrs. Flores shared that it was an enriching conversation, and she hoped there was enough information for me to triangulate all the data needed for my qualitative study.

Coding results. After the data had been collected, I analyzed data using ATLAS.TI software, for in vivo coding. First, I assessed students' achievement writing essays with a rubric. Individually, I revised their Spanish essays and then their English essays to check for skills' transfer from Spanish to English. Second, I analyzed the students' responses in the survey, identifying high and low averages between the dimensions of the survey, as well as the statements within the dimensions. Third, I analyzed and coded their illustrations, narratives, and transcriptions of the focus group to identify common themes based on the coding classification provided by Attride-Stirling (2001), Miles and Huberman (1984), and Saldaña (2009).

\section{Role of the Researcher}

My study explored how simultaneous bilingual middle school students respond to the Bridge strategy between two languages in a humanities dual language/immersion class. I have been teaching for 24 years in a variety of settings. For the last three years, I 
have been working with simultaneous bilingual students. "Insider observation is considered one of the most important and also difficult studies to conduct in qualitative research" (Hermann, 1989, as citied in Duty, 2015, p. 62). Because the research setting was in my own classroom, I collected the data as an "insider observer." Glesne (2016) recommended that this type of "backyard" (p. 49) research (i.e., insider observer) is appropriate for teachers, and this recommendation reflects in my case. I have connections not only with the students but also with the parents and school administrators.

This backyard research approach is also a familiar place for myself as a researcher, which influences the bias with which my study might be affected. Glesne (2016) mentioned that "complete objectivity is not possible and that all researchers are biased by their historical contexts and sociocultural experiences" (p. 8). Krathwohl (2009) also recommended that the researcher should make a conscious recognition of their judgments, recording them in a memo so those judgments are accountable for when analyzing data. Furthermore, Merriam (2009) explained that in phenomenology the researcher "explores his or her own experiences, in part to examine dimensions of the experience and in part to become aware of personal prejudices, viewpoints, and assumptions" (p. 25) prior to interviewing. This means that my own perspectives and understanding of bilingualism influenced the way I thought about analyzing the data; therefore, I used four different instruments to triangulate the data for trustworthiness. Figure 10 provides an overview of the limitations I have described in this section. 
$\square \quad 12$ students

Over 3-month period

I I am the teacher and I collected the data, except for the focus group conducted by a Teacher-on-Special-Assignment

Figure 10. Researcher limitations.

The research question for this study is: How do simultaneous bilingual middle school students respond to becoming biliterate when taught using the Bridge strategy in a humanities dual language/immersion class? The sub-questions of my study: What do students' achievement scores tell me about developing biliteracy using the Bridge strategy? What attitudes do students have toward becoming biliterate?, How do students transfer literacy skills learned through the Bridge to new situations in the other language? How do students respond to becoming biliterate in the context of using the Bridge strategy?

First, from the survey I learned what the student scores on the rubric tell me about their achievement in using the Bridge strategy to read and write in two languages and what experience the students have had with the Bridge strategy prior to this class. From the illustrations, narratives, and the focus group I learned how the students responded to the Bridge activities. What helps them learn? What seems to be a challenge for them? What do students think about being bilingual in general — as a way to learn to read and write? For this study, I asked six colleagues-teachers to read the questions written for my focus group, survey, draw-a-bilingual student instructions, and the free narrative instructions for the draw-a-bilingual student writing. I collected data from the surveys, 
focus group interviews, drawings, and narratives for triangulation and analysis and to reduce bias as well.

Analysis. The qualitative analysis of data follows the Attride-Sterling (2001) thematic networks assisted with the ATLAS.ti software for the focus group and in vivo coding of the surveys, drawings, and narratives in addition to the rubrics used for the narrative writing papers in English and Spanish. Following Attride-Stirling, I broke the data down into themes, exploration of the themes, and interpretation of the patterns identified. The breakdown of the data occurred in three different phases, as represented in Figure 11.
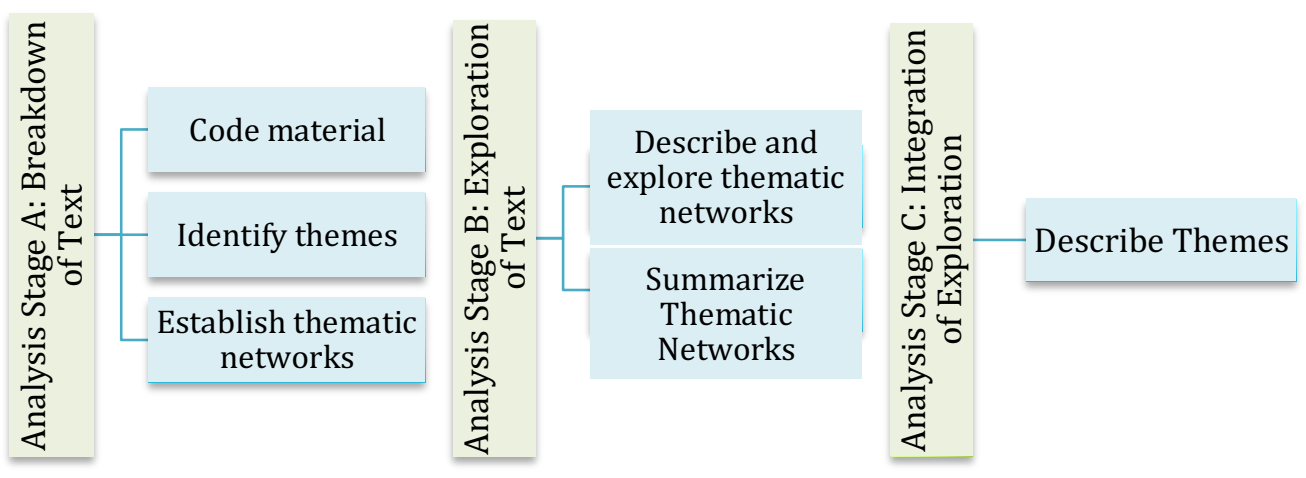

Figure 11. Thematic networks: An analytic tool for qualitative research. Adapted from Attride-Sterling (2001, p. 391).

In Chapter 4, I will analyze the results as observed in the field, the presentation and meaning of the data collected for the study, and the meaning and interpretation of those results. To classify the data into themes, I combined different techniques from Attride-Stirling (2001), Miles and Huberman (1984), and Saldaña (2009) on coding qualitative analyses. 


\section{Chapter 4: Analysis and Findings}

The purpose of this study was to explore how simultaneous bilingual middle school students respond to becoming biliterate in Spanish and English as a result of participation in a humanities dual language/immersion class, taught through the instructional strategy the Bridge. The main research question was: How do simultaneous bilingual middle school students respond to becoming biliterate when taught using the Bridge strategy in a humanities dual language/immersion class? The sub-questions for this study were:

1. What do students' achievement scores tell me about developing biliteracy using the Bridge strategy?

2. What attitudes do students have toward becoming biliterate?, How do students transfer literacy skills learned through the Bridge to new situations in the other language?

3. How do students respond to becoming biliterate in the context of using the Bridge strategy?

This chapter describes in greater detail the findings of the study in two parts:

1. Short answers and findings of the data collected from the instruments used in the study: (a) the students' achievement assessment; (b) a survey that explored students' ability to use the Bridge strategy to advance biliteracy and their feelings about becoming biliterate; (c) students' drawings about their conceptions of a bilingual student; (d) narratives of students' drawings; and (e) focus group discussion transcribed and coded.

2. Themes across all data sources that led to the significant themes of study in this research.

In the final section of this chapter, I will discuss the limitations, and present a summary of the results of the study. 


\section{Section 1: Data Analysis by Instrument}

This first section presents the analysis of the instruments used in this study for trustworthiness.

Achievement. Students followed the narrative check list (see Appendix H) to demonstrate achievement of writer's craft.

Table 6

Students' Achievement in Biliteracy: Scores Across the Three Dimensions of the Text.

\begin{tabular}{|c|c|c|c|c|c|}
\hline \multirow{3}{*}{$\begin{array}{l}\text { Dimensions } \\
\text { of the Text }\end{array}$} & \multirow{3}{*}{ Subskills of the Dimension } & \multicolumn{4}{|c|}{ Students at the Proficiency Level } \\
\hline & & \multicolumn{2}{|c|}{ Written in English } & \multicolumn{2}{|c|}{ Written in Spanish } \\
\hline & & Developing & Proficient & Developing & Proficient \\
\hline $\begin{array}{l}\text { Structure of } \\
\text { the Text }\end{array}$ & $\begin{array}{l}\text { Overall Story, lead, } \\
\text { transitions, ending, } \\
\text { organization }\end{array}$ & 8 & 4 & 8 & 4 \\
\hline $\begin{array}{l}\text { Development } \\
\text { of Text }\end{array}$ & Elaboration, craft & 9 & 3 & 7 & 5 \\
\hline $\begin{array}{c}\text { Writing } \\
\text { Conventions }\end{array}$ & $\begin{array}{l}\text { Spelling, punctuation and } \\
\text { sentence structure }\end{array}$ & 10 & 2 & 10 & 2 \\
\hline
\end{tabular}

The data in Table 6 shows the levels of achievement in English and Spanish for the 12 students in my study. In the students' achievement column, the students' writing is assessed across three dimensions: (a) Structure of the text; (b) Development of text; and (c) Writing conventions. They are assessed as either "developing" or "proficient" in English and in Spanish. Results are similar in the structure of the text dimension and in the writing conventions dimensions. However, the development of the text dimension shows considerable differences between "developing" and "proficient" in English and Spanish. 
The first row in Table 6, structure of the text, shows $67 \%(n=8)$ of students at the developing level and 33\% $(n=4)$ of students as proficient in English as well as in Spanish. Some examples of structure of the text are: idea, lesson or theme in student's writing, lead, transitions, and organization.

The second row in Table 6, development of text, shows $75 \%(n=9)$ of students at the developing level and 25\% $(n=3)$ of students at the proficient level in English. Whereas in Spanish, it shows 58\% $(n=7)$ of students are developing, and $42 \%(n=5)$ of students are proficient in text development. Some examples of text development are describing realistic characters, attention to detail, action, dialogue, and characters' internal thinking to make the stories interesting for the audience. They also use descriptions, figurative language and symbolism, and use a distinctive language to develop the personality of their characters in the story.

The third row in Table 6, writing conventions, shows $83 \%(n=10)$ of students at the developing level, and 17\% $(n=2)$ of students as proficient in English as well as in Spanish. Some examples of writing conventions are spelling, punctuation, and sentence structure.

I am including this data in the study to show that the students are becoming biliterate. This is necessary to establish, because the other instruments (survey, drawings, free narrative, and focus group) from where data was collected, require the students to write and speak about their biliteracy. The data in Table 6 shows that the students are biliterate and have enough skill to assess their experience of becoming biliterate. A 
sampling of student work and rubrics used to evaluate their literacy skills can be found in Appendix $\mathrm{O}$ and $\mathrm{H}$.

Survey. To assess students' viewpoints on biliteracy attainment, I used a fourcategory survey, adapted from Gardner and Lambert's (1972) research on attitudes and motivations to learn a second language. Table 7 presents the summary: mean and standard deviation (Likert scale: 5 strongly agree, and 1 is the lowest level of agreement) across four dimensions: attitude, motivation, confidence, and performance. The complete survey with the data for each student and all the means and standard deviations as well as the analysis is in Appendix M.

\section{Table 7}

The Four Dimensions on Survey in a Likert Scale

\begin{tabular}{|c|c|c|}
\hline Dimension & Mean & Standard Deviation \\
\hline Attitude/Pride & 4.60 & 0.60 \\
\hline Motivation & 4.48 & 0.83 \\
\hline Confidence & 4.09 & 0.93 \\
\hline Performance & 3.97 & 0.82 \\
\hline
\end{tabular}

Adapted from Gardner and Lambert's (1972) research on attitudes and motivations to learn a second language.

As can be seen from Table 7, the highest mean in a dimension is for student attitude and pride in becoming bilingual $(\bar{x}=4.60)$. The range of scores in this category were from 4.08 to 4.83 . As an example, the items within this category with the highest score are

- 'It is important for me to learn Spanish'. $(\bar{x}=4.83)$

- 'I feel proud to be able to speak Spanish'. $(\bar{x}=4.83)$ 
The dimension with the next highest score was student motivation to learn to be biliterate $(\bar{x}=4.48)$. The range of scores within this category was from 4.08 to 4.75 . The items with the highest score within the motivation section are:

- $\quad$ Being bilingual will be of great benefit to my career. $(\bar{x}=4.75)$

- It is important for my parents that I am bilingual. $(\bar{x}=4.67)$

The third section shows students' confidence to express themselves in English and Spanish in a variety of situations with a mean score of 4.09. The range of scores within this category was from 3.67 to 4.54 . The two items with the highest score are:

- I feel that I can confidently express myself in Spanish. $(\bar{x}=4.54)$

- I feel that I can confidently express myself in English. $(\bar{x}=4.25)$

The fourth section is performance, showing students' use of different strategies to advance literacy in both languages with a mean of 3.97. The two items with the highest score are:

- Using the strategies from the Bridge has helped me better utilize one language to improve my literacy in the other. $(\bar{x}=4.20)$

- Using one language to explain the other one from 'the Bridge' has helped me better understand one language to improve my literacy in the other. $(\bar{x}=$ 4.17)

The scores indicate that attitude and motivation are higher than confidence and performance. Since attitude and motivation are high, students seem to have overcome the affective filter that can inhibit language learning and are in a position to continue to develop their biliteracy. The students assess themselves lowest in performance. It seems that students recognize that they are acquiring the skills to become biliterate, and this 
process might inhibit their ability to communicate in the less dominant language, depending on the predominant language spoken at home.

Draw-a-Bilingual Student. Inspired by Goodenough (as cited in Chambers, 1983) and Mead and Metraux (as cited in Chambers, 1983), I asked students to draw a bilingual student. Figure 12 shows the results of the analysis of drawings of the 12 students in response to the simple direction: "Draw-a bilingual student." From this analysis, there were 16 traits identified across all the drawings. Not every drawing had all the traits. The students' drawings can be found in Appendix N.

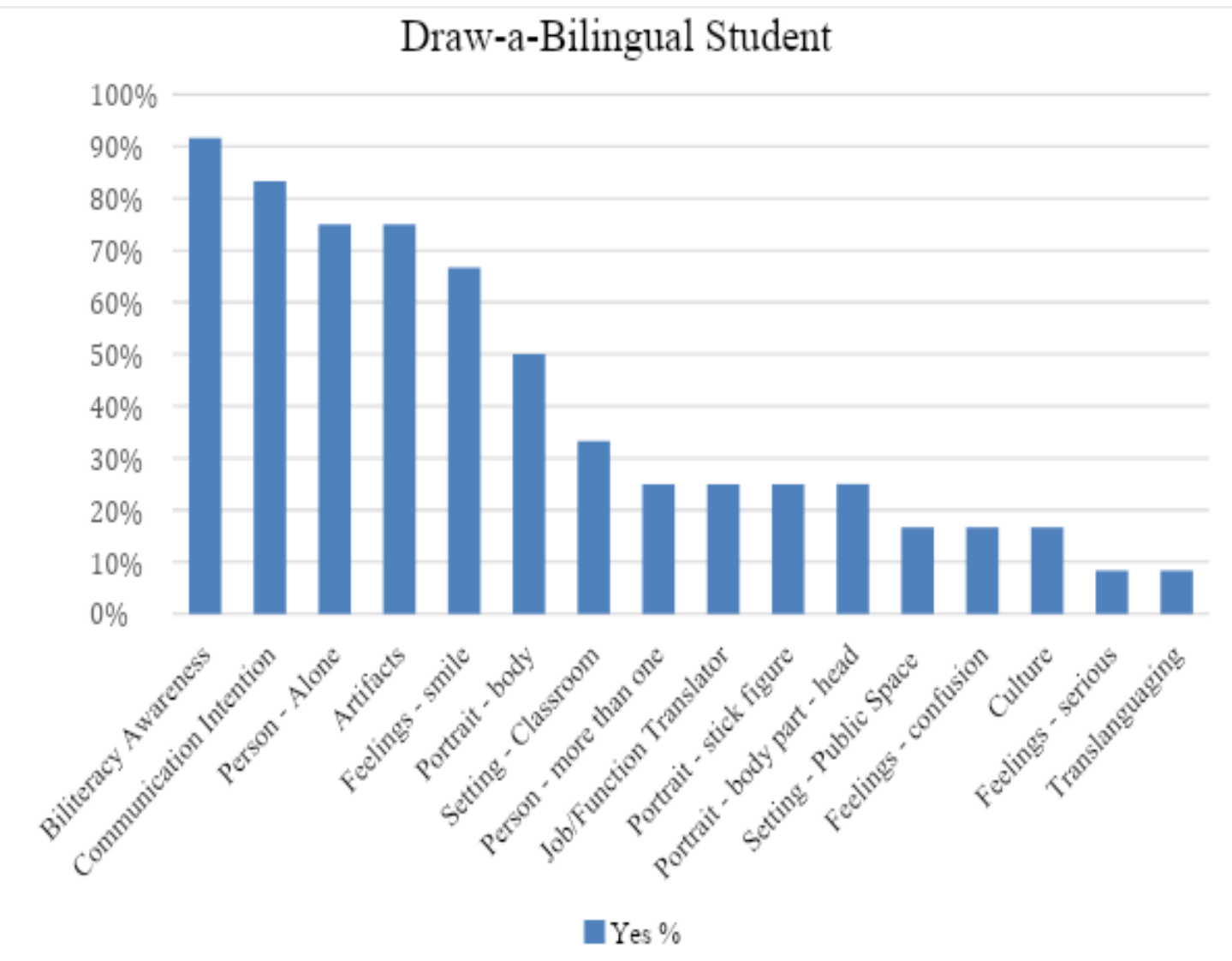

Figure 12. Labels identified in students' drawings of a bilingual student. 
Figure 12 shows the frequency as a percentage with which each trait occurs across all the drawings. For example, $92 \%(n=11)$ of the drawings had a trait that indicated the student had an awareness of his or her biliteracy. Also, $83 \%$ of the drawings show that students intend to communicate as biliterates (communication intention). $75 \%$ of students $(n=9)$ incorporated the context in which they are learning the language and included pictures of classroom artifacts like books, flags, desk, projection screens, and notebooks.

The imagination and creativity of students while drawing allows for a diverse manifestation of the traits. As a consequence, interpretation can be inaccurate. When I asked students to draw a bilingual student, they all drew people, or as indicated a student, and created explicit images to accompany their human. For example, some students drew a human either writing, reading, or translating for someone. Their person had a communication intention represented through dialogue or indicating they were presenting to an audience. They added artifacts, for example, a desk, some books, a journal, a computer, a projection screen, and flags. They also represented some feelings, for example content, confused or serious. Furthermore, they drew a place where the bilingual student interacted with both languages for example a classroom or a restaurant. Finally, they connected their ability to communicate in more than one language to a job or showed themselves as a translator. Figures 13, 14 and 15 show the students' drawings accompanied by the corresponding narrative. 


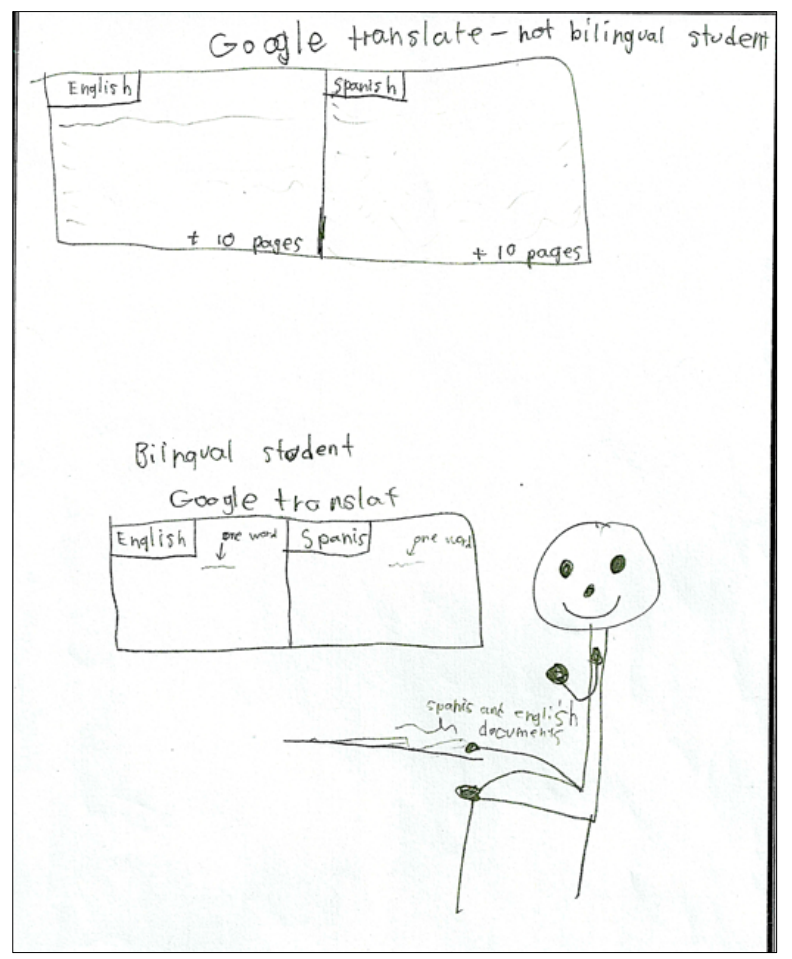

Student 1:

A bilingual student should be able to create a Spanish-English document without putting the hole thing through Google Translate. In addition, a student without 2 languages will put some part of his /her paragraph through Google translate, and they will put at least 30 words through Google translate. Google does not get all of the words right in the correct tense, so your entire effort could go to the trash. If you have 2 languages, then if you know one word in one of the languages, then you could probably figure it out in the other language.

The reason for this are cognates. Similar words between different languages. For example: in Spanish it is elefante. In English, it is elephant. 2 words, different languages, but yet the same.

Figure 13. Minerva's drawing and her free narrative. 


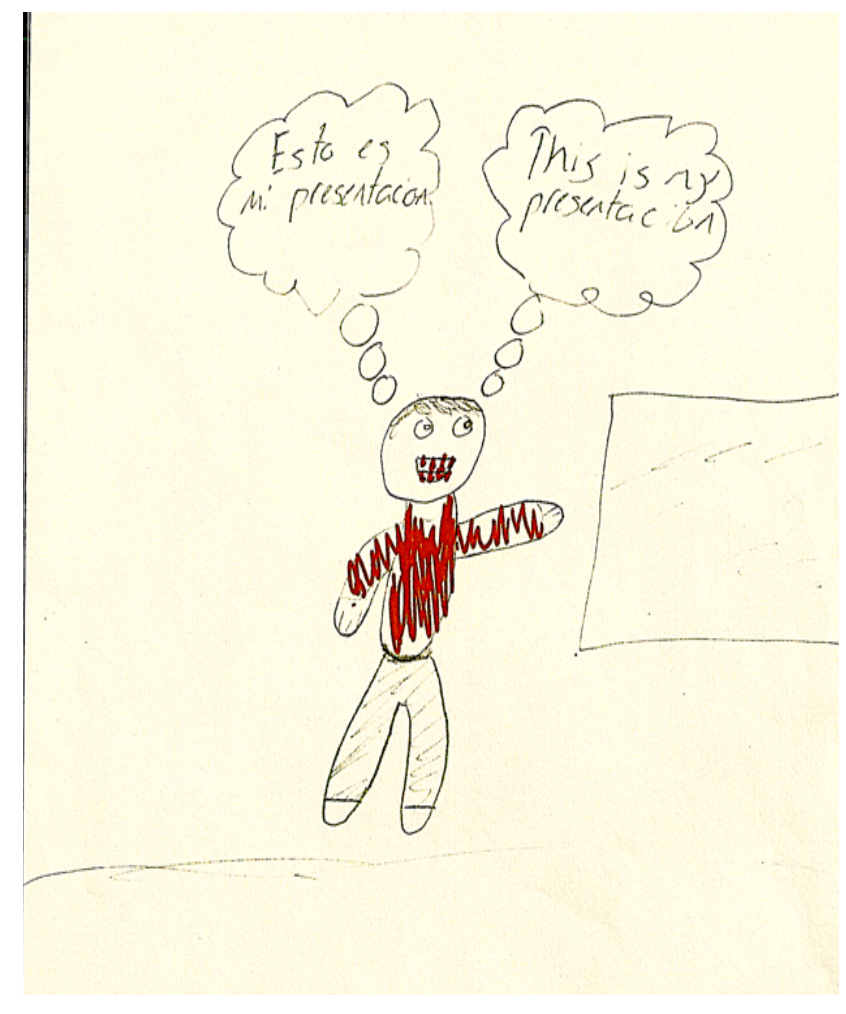

Student 6:

My drawing of a bilingual student is showing a student who is gonna preséntate a presentación to his class and family since he's bilingual he doesn't know if he should presentate it in English or Spanish that's why he has both ways of saying it in his mind which he has to decide. This is also good cause he is able to prestate it in both languages for parents of others if they don't understand it. I'm glad to be bilingual.

Figure 14. Julio César's drawing and his free narrative. 

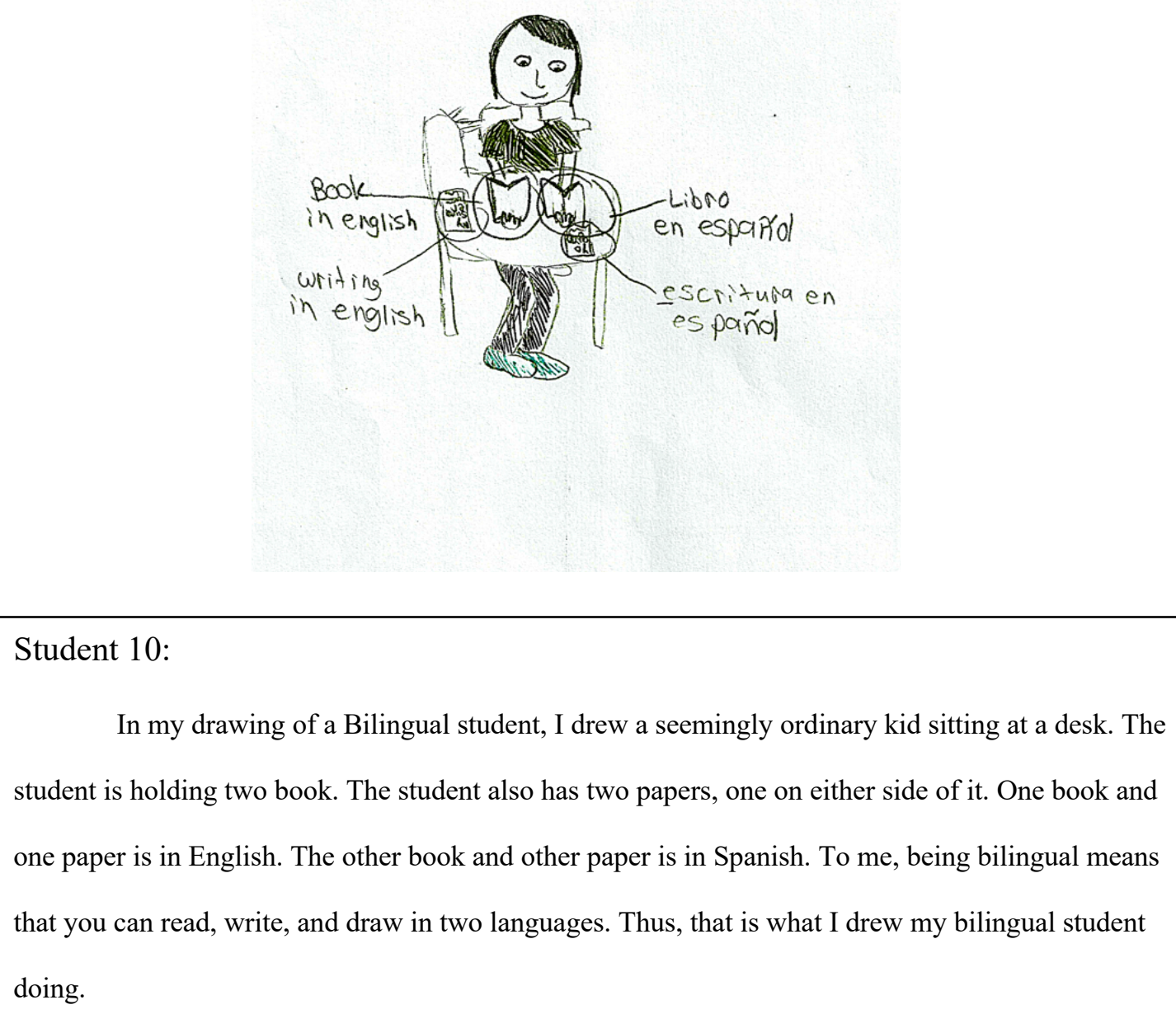

Figure 15. Xóchitl's drawing and her free narrative.

Narrative: Describe your Drawing. Students drew their idea of a bilingual student. To add an interpretation as close as to the intention of the student, I asked them to add a narrative to their drawing. In Figure 16 I present the repeated patterns codes identified from the students' narratives. I classified the qualities of their drawing, labeled them and organized them into 10 categories. Each category shows the frequency in which this characteristic appeared across the 12 narratives. 


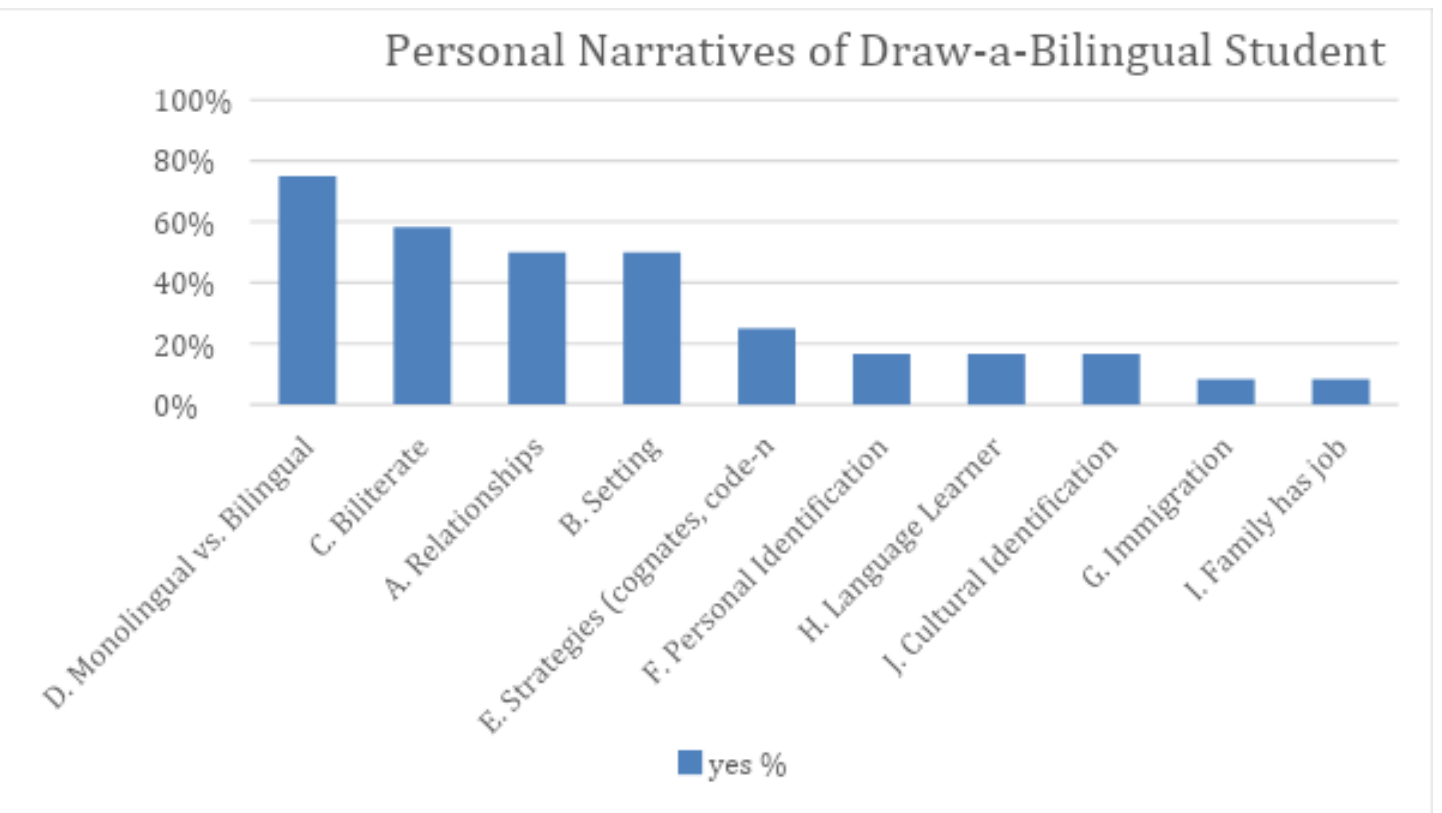

Figure 16. Code occurrence in personal narratives of draw-a-bilingual-student.

Figure 16 shows $75 \%(n=9)$ of the narratives described a characteristic of a monolingual vs. bilingual person. For example, Minerva wrote that "a bilingual student should be able to create a Spanish-English document without putting the whole thing through Google Translate." Also, 58\% $(n=7)$ of the narratives indicate that students understand what it means to be "biliterate." For example, Xochitl wrote "To me, being bilingual means that you can read, write, and draw in two languages."

The process of putting into words what the students drew seems to have prompted them to do more thinking about what it means to be a bilingual and biliterate person. $25 \%$ $(n=3)$ of the students wrote about teaching strategies like translanguaging and recognition of cognates in their descriptions. Minerva added to her narrative:

Google does not get all of the words right in the correct tense, so your entire effort could go to the trash. If you have 2 languages, then if you know one word in one of the languages, then you could probably figure it out in the other language. 
The reason for these are cognates. Similar words between different languages. For example: in Spanish it is elefante. In English, it is elephant. 2 words, different languages, but yet the same.

In addition, students described the importance of communicating with people from diverse cultural backgrounds. $50 \%(n=6)$ of the students talked about the importance of relationships. For example, Julio Cesar wrote: "This is also good cause he is [able] to do a presentation in both languages for parents of others if they don't understand it. I'm glad to be bilingual."

Focus Group. The focus group lasted 1 hour and 20 minutes. Students' discussion was led by six questions that intended to gather information on:

- the importance of being biliterate for the students themselves and for their families;

- their confidence to communicate in English and Spanish in different environments;

- their motivation to become biliterate;

- the support they identified from their classes in a dual language program; and

- their projections on how they think being bilingual and biliterate will enrich their lives.

The questions were:

1. With whom do you speak in English and with whom in Spanish?

2. What are you more comfortable talking about in Spanish and what in English?

3. Describe how your family, friends, and teachers support you in becoming bilingual.

4. Tell me what activities from the Bridge -cognates, translanguaging, code mixing, use one language to explain the other one -help you improve your reading and writing in Spanish and English.

5. Tell me about your motivation to learn Spanish. 
6. Tell me about a couple situations where you feel being bilingual has been helpful to you.

From Table 8, it can be seen that students express confidently what it means to

them to become biliterate 17 times. For example, a student during the focus group

discussion said:

I would say that knowing another language opens up so many things you could do and so many things you can understand. Speaking in another language, knowing more than one, just turns your brain to another level. And also being able to translate for other people it's another way your brain can get smarter. And how it's really cool to be able to do all that stuff as second nature.

\section{Table 8}

Occurrence of Codes in Focus Group

\begin{tabular}{|l|c|}
\hline \multicolumn{1}{|c|}{ Codes } & Occurrences of Theme's Codes \\
\hline biliteracy & 17 \\
\hline program structure & 10 \\
\hline self-motivation & 9 \\
\hline pride & 7 \\
\hline community & 7 \\
\hline professional career & 7 \\
\hline benefit & 5 \\
\hline family & 3 \\
\hline cultural diversity & 1 \\
\hline Travel & 1 \\
\hline
\end{tabular}


Another student added: "Bilingual has been helpful to me, cause when I watch a TV show in Spanish, I will be able to understand the plot twists - all that's going on. And also, I will be able to communicate with others in English or in Spanish."

A third students said: "Well what motivates me is my parents and for me it's good to speak English and Spanish, because when we need to present something in one language, we can do it in whatever language."

These quotes show that middle school students in this study have experienced schooling in a dual language program and confidently talk about how they have developed literacy skills in English and Spanish. They acknowledge the value of becoming biliterate and they can write about it, create an image to represent their thinking or talk about it.

\section{Section 2: Overarching Themes Across All Data Sources}

The following section describes the overarching themes derived from and an analysis across all the data corpus in the study.

As mentioned in Chapter 3, I combined the different analytical techniques from Attride-Stirling (2001), Miles and Huberman (1984), and Saldaña (2009) for qualitative coding analysis.

According to Saldaña (2009), "a theme is a phrase or sentence that identifies what a unit of data is about and what it means. A theme is an outcome of coding, categorization, and analytic reflection" (p. 139). I based my "judgment call" (p. 7) to first, code students' experiences about developing biliteracy. Then, I grouped the pattern ideas to develop "an 'overarching theme' from the data corpus" (p. 139). 
In the following subsections, I will discuss the overarching themes derived from the pattern code's frequency. Table 8 maps the codes to the overarching themes within each data corpus.

The five overarching themes identified in the data corpus for this study are: (1) Acknowledge the positive role of family, (2) Develop confidence in becoming biliterate, (3) Appreciate using biliteracy skills in the community, (4) Envision the value of biliteracy in their future, and (5) Appreciate bilingual programs in our schools. Figure 17 illustrates these five themes and the relationship with the social cognitive theory (Bandura, 1986).

\section{Overarching Themes}

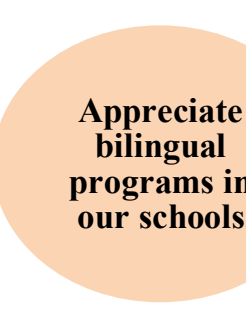

Acknowledge the positive role of family
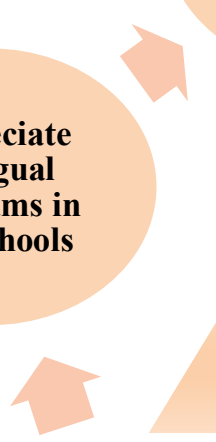

(1)
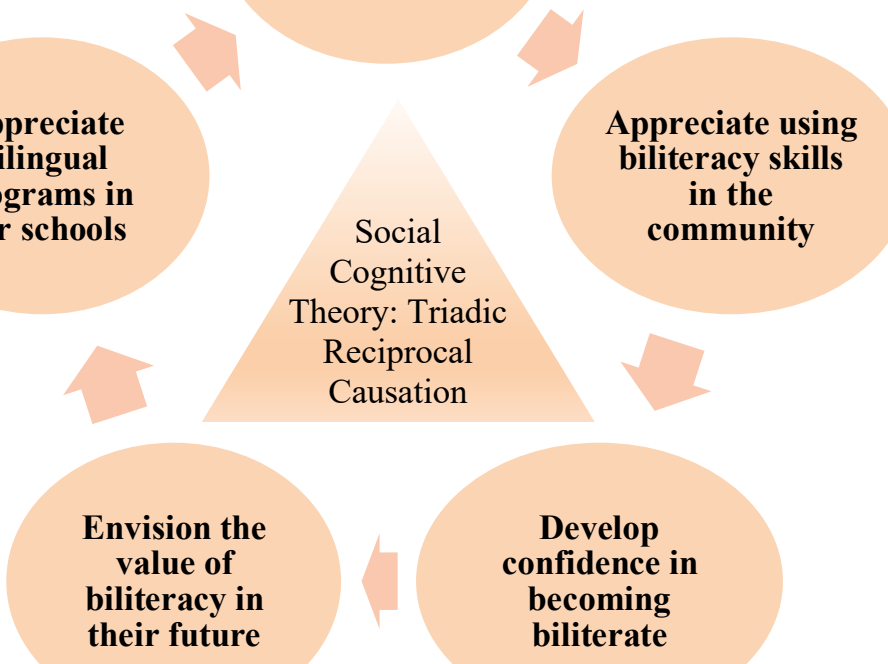

Develop confidence in becoming biliterate

Figure 17. Overarching themes of the study. 
Table 9 presents a closer look at how the overarching themes were derived from patterns in the codes. Taking it further, Table 10 presents some in vivo examples from the data sources for the overarching themes. I am referring to both tables in the following paragraphs of Section 2 .

\section{Table 9}

\section{Mapping of Codes to Themes}

\begin{tabular}{|c|c|c|c|c|}
\hline Themes & Codes for Survey & $\begin{array}{l}\text { Codes for Draw- } \\
\text { a-Bilingual- } \\
\text { Student }\end{array}$ & $\begin{array}{l}\text { Codes for Free } \\
\text { Narrative }\end{array}$ & $\begin{array}{l}\text { Codes for } \\
\text { Focus Group }\end{array}$ \\
\hline $\begin{array}{l}\text { Acknowledge } \\
\text { the positive } \\
\text { role of family }\end{array}$ & $\begin{array}{l}\text { - D1. I would like to learn more } \\
\text { about my Hispanic heritage. } \\
\text { - D5. It is important to my } \\
\text { parents that I am bilingual. }\end{array}$ & $\begin{array}{l}\text { - Language } \\
\text { learner } \\
\text { - Culture }\end{array}$ & - Relationships & $\begin{array}{l}\text { - Benefit/ } \\
\text { Additive } \\
\text { - Family }\end{array}$ \\
\hline $\begin{array}{l}\text { Develop } \\
\text { confidence in } \\
\text { becoming } \\
\text { biliterate }\end{array}$ & $\begin{array}{l}\text { - A1. Using the "cognates" } \\
\text { strategy from 'the Bridge' has } \\
\text { helped me better utilize one } \\
\text { language to improve in the } \\
\text { other. } \\
\text { - A2. Using the } \\
\text { "translanguaging" strategy } \\
\text { from 'the Bridge' has helped } \\
\text { me better utilize one language } \\
\text { to improve my literacy in the } \\
\text { other. } \\
\text { - A3. Using the "code mixing" } \\
\text { strategy from 'the Bridge' has } \\
\text { helped me better utilize one } \\
\text { language to improve my } \\
\text { literacy in the other. } \\
\text { - A4. Using one language to } \\
\text { explain the other one from 'the } \\
\text { Bridge' has helped me better } \\
\text { understand one language to } \\
\text { improve my literacy in the } \\
\text { other. } \\
\text { - B1. I feel that I can } \\
\text { confidently express myself in } \\
\text { English. } \\
\text { - B2. I feel that I can } \\
\text { confidently express myself in } \\
\text { Spanish. } \\
\text { - B3. I feel that I can } \\
\text { confidently express myself } \\
\text { during class. }\end{array}$ & $\begin{array}{l}\text { - Drew a single } \\
\text { individual } \\
\text { - Drew an } \\
\text { individual } \\
\text { - Feeling happy } \\
\text { - Biliteracy } \\
\text { awareness } \\
\text { - Language } \\
\text { learner }\end{array}$ & $\begin{array}{l}\text { - Monolingual } \\
\text { vs. Bilingual } \\
\text { - Personal } \\
\text { Identification } \\
\text { - Language } \\
\text { Learner }\end{array}$ & $\begin{array}{l}\text { - Biliteracy } \\
\text { - Pride } \\
\text { - Self- } \\
\text { motivation }\end{array}$ \\
\hline
\end{tabular}


Table 9 (continued)

\begin{tabular}{|c|c|c|c|c|}
\hline Themes & Codes for Survey & $\begin{array}{l}\text { Codes for Draw- } \\
\text { a-Bilingual- } \\
\text { Student }\end{array}$ & $\begin{array}{l}\text { Codes for Free } \\
\text { Narrative }\end{array}$ & $\begin{array}{l}\text { Codes for } \\
\text { Focus Group }\end{array}$ \\
\hline $\begin{array}{l}\text { Develop } \\
\text { confidence in } \\
\text { becoming } \\
\text { biliterate }\end{array}$ & $\begin{array}{l}\text { - B4. It is important to practice } \\
\text { - I am not afraid to make } \\
\text { mistakes. } \\
\text { - B5. I can rely on my English } \\
\text { to help me understand and } \\
\text { respond in Spanish and the } \\
\text { other way around. } \\
\text { - C1. It is important for me to } \\
\text { learn Spanish. } \\
\text { - C2. I feel proud to be able to } \\
\text { speak Spanish. } \\
\text { - C3. I am proud that I can } \\
\text { speak two languages. }\end{array}$ & & & \\
\hline $\begin{array}{l}\text { Appreciate } \\
\text { using } \\
\text { biliteracy } \\
\text { skills in the } \\
\text { community }\end{array}$ & $\begin{array}{l}\text { - C5. Speaking Spanish makes } \\
\text { me feel more connected to my } \\
\text { Hispanic community. } \\
\text { - D1. I would like to learn more } \\
\text { about my Hispanic heritage. } \\
\text { - D4. Being bilingual will be of } \\
\text { great benefit to my career. } \\
\text { - D5. It is important to my } \\
\text { parents that I am bilingual. }\end{array}$ & $\begin{array}{l}\text { - Communication } \\
\text { intention } \\
\text { - Artifacts } \\
\text { - Setting } \\
\text { (Classroom \& } \\
\text { Public Space) } \\
\text { - Translanguaging } \\
\text { - Culture }\end{array}$ & $\begin{array}{l}\text { - Relationships } \\
\text { - Setting }\end{array}$ & $\begin{array}{l}\text { - Community } \\
\text { - Cultural } \\
\text { Diversity }\end{array}$ \\
\hline $\begin{array}{l}\text { Envision the } \\
\text { value of } \\
\text { biliteracy in } \\
\text { their future }\end{array}$ & $\begin{array}{l}\text { - C4. My life is richer, because } \\
\text { I speak two languages. } \\
\text { - D3. Learning Spanish is } \\
\text { important to me. }\end{array}$ & $\begin{array}{l}\text { - Biliteracy } \\
\text { awareness } \\
\text { - Job function as a } \\
\text { translator }\end{array}$ & $\begin{array}{l}\text { - Biliterate } \\
\text { - Strategies }\end{array}$ & $\begin{array}{l}\text { - Professional } \\
\text { Career } \\
\text { - Travel }\end{array}$ \\
\hline $\begin{array}{l}\text { Appreciate } \\
\text { bilingual } \\
\text { programs in } \\
\text { our schools }\end{array}$ & $\begin{array}{l}\text { - A5. Using the strategies from } \\
\text { 'the Bridge' has helped me } \\
\text { better utilize one language to } \\
\text { improve my literacy in the } \\
\text { other. } \\
\text { - B4. It is important to practice } \\
\text { - I am not afraid to make } \\
\text { mistakes. } \\
\text { - D2. I would like to do as well } \\
\text { academically in Spanish as I do } \\
\text { in English. }\end{array}$ & $\begin{array}{l}\text { - Biliteracy } \\
\text { awareness } \\
\text { - Language } \\
\text { learner } \\
\text { - Translanguaging }\end{array}$ & $\begin{array}{l}\text { - Language } \\
\text { Learner }\end{array}$ & $\begin{array}{l}\text { - Biliteracy } \\
\text { - Program } \\
\text { Structure }\end{array}$ \\
\hline
\end{tabular}


Table 10

Overarching Themes Derived from the Survey, Draw-a-Bilingual-Student, Free Narrative and Focus Group

\begin{tabular}{|c|c|c|c|c|}
\hline Themes & $\begin{array}{c}\text { Survey } \\
\text { Categories } \\
\text { with } \\
\text { Frequency }\end{array}$ & $\begin{array}{c}\text { Traits Identified } \\
\text { in Draw-a- } \\
\text { Bilingual- } \\
\text { Student** }\end{array}$ & $\begin{array}{c}\text { Quotations from the Free } \\
\text { Narrative }\end{array}$ & $\begin{array}{l}\text { Quotations from } \\
\text { the Focus Group }\end{array}$ \\
\hline $\begin{array}{l}\text { Acknowledge } \\
\text { the positive } \\
\text { role of family }\end{array}$ & $\begin{array}{l}\text { D5. It is } \\
\text { important to } \\
\text { my parents } \\
\text { that I am } \\
\text { bilingual } \\
(100 \%)^{*}\end{array}$ & $\begin{array}{l}\text { Culture }(17 \%) \\
\text { Language learner } \\
(33 \%)\end{array}$ & $\begin{array}{l}\text { "My drawing of a bilingual } \\
\text { student is showing a student } \\
\text { who is gonna preséntate a } \\
\text { presentación to his class and } \\
\text { family since he's bilingual } \\
\text { he doesn't know if he should } \\
\text { presentate it in English or } \\
\text { Spanish" }\end{array}$ & $\begin{array}{l}\text { "My family has } \\
\text { pushed me ... to } \\
\text { talk both" } \\
\text { "My parents have } \\
\text { alwya wanted me } \\
\text { and my siblings to } \\
\text { learn Spanish" }\end{array}$ \\
\hline $\begin{array}{l}\text { Develop } \\
\text { confidence in } \\
\text { becoming } \\
\text { biliterate }\end{array}$ & $\begin{array}{l}\text { C1. It is } \\
\text { important for } \\
\text { me to learn } \\
\text { Spanish } \\
(100 \%)^{*} \\
\text { C2. I feel } \\
\text { proud to be } \\
\text { able to speak } \\
\text { Spanish } \\
(100 \%)^{*} \\
\text { C3. I am } \\
\text { proud that I } \\
\text { can speak } \\
\text { two } \\
\text { languages } \\
(100 \%)^{*}\end{array}$ & $\begin{array}{l}\text { Biliteracy } \\
\text { awareness } \\
(92 \%)^{* *} \\
\text { Feeling content } \\
(67 \%)^{* *}\end{array}$ & $\begin{array}{l}\text { "If you have } 2 \text { languages, } \\
\text { then if you know one word } \\
\text { in one of the languages, } \\
\text { then you could probably } \\
\text { figure it out in the other } \\
\text { language." } \\
\text { "He said "Si pero no } \\
\text { endiendo lot fo English.' } \\
\text { Then the girl said I can } \\
\text { help you talk Englsih the } \\
\text { boy said 'okay yo te help } \\
\text { you a hablar español. Both } \\
\text { of the kids mixed Spanish } \\
\text { and English to help each } \\
\text { other communicate."" } \\
\text { "To me, being bilingual } \\
\text { means that you can read, } \\
\text { write, and draw in two } \\
\text { languages. Thus, that is what } \\
\text { I drew my bilingual student } \\
\text { doing." }\end{array}$ & $\begin{array}{l}\text { "Really cool to be } \\
\text { able to know two } \\
\text { languages" } \\
\text { "being bilingual } \\
\text { is like being two } \\
\text { persons in one } \\
\text { whole person" }\end{array}$ \\
\hline $\begin{array}{l}\text { Appreciate } \\
\text { using } \\
\text { biliteracy } \\
\text { skills in the } \\
\text { community }\end{array}$ & $\begin{array}{l}\text { C5. Speaking } \\
\text { Spanish } \\
\text { makes me } \\
\text { feel more } \\
\text { connected to } \\
\text { my Hispanic } \\
\text { community } \\
(83 \%)^{*}\end{array}$ & $\begin{array}{l}\text { Communicative } \\
\text { intention } \\
(83 \%)^{* *} \\
\text { Job/Function } \\
\text { Translator } \\
(25 \%)^{* *}\end{array}$ & $\begin{array}{l}\text { "I believe being bilingual is } \\
\text { being able to translate to } \\
\text { someone and be able to go } \\
\text { to a country where people } \\
\text { speak your } 2 \text { nd language } \\
\text { every day and may not } \\
\text { know another and be able } \\
\text { to speak fluently with } \\
\text { them. } \\
\text { "The lady is trying to order a } \\
\text { shake from McDonalds but } \\
\text { can't speak fluent English. } \\
\text { When the worker asks if she } \\
\text { can repeat it he can't }\end{array}$ & $\begin{array}{l}\text { "opportunities } \\
{[\ldots . \text {. . to help other }} \\
\text { people like } \\
\text { translate this } \\
\text { language to } \\
\text { another language" } \\
\text { "Helping my } \\
\text { parents cause their } \\
\text { main language is } \\
\text { Spanish and so at a } \\
\text { store or calling or } \\
\text { wahtever I help } \\
\text { them translate" }\end{array}$ \\
\hline
\end{tabular}


Table 10 (continued)

\begin{tabular}{|c|c|c|c|c|}
\hline Themes & $\begin{array}{c}\text { Survey } \\
\text { Categories } \\
\text { with } \\
\text { Frequency }\end{array}$ & $\begin{array}{c}\text { Traits Identified } \\
\text { in Draw-a- } \\
\text { Bilingual- } \\
\text { Student** }\end{array}$ & $\begin{array}{c}\text { Quotations from the Free } \\
\text { Narrative }\end{array}$ & $\begin{array}{l}\text { Quotations from } \\
\text { the Focus Group }\end{array}$ \\
\hline $\begin{array}{l}\text { Appreciate } \\
\text { using } \\
\text { biliteracy } \\
\text { skills in the } \\
\text { community }\end{array}$ & & & $\begin{array}{l}\text { understand what she is } \\
\text { saying since he doesn't } \\
\text { speake Spanish. I ask the } \\
\text { lady in Spanish what she } \\
\text { wants to order and once she } \\
\text { told me what she wanted to } \\
\text { order, I talked with the } \\
\text { worker with fluent English." }\end{array}$ & \\
\hline $\begin{array}{l}\text { Envision the } \\
\text { value of } \\
\text { biliteracy in } \\
\text { their future }\end{array}$ & $\begin{array}{l}\text { D4. Being } \\
\text { bilingual will } \\
\text { be of great } \\
\text { benefit to my } \\
\text { career } \\
(100 \%)^{*}\end{array}$ & $\begin{array}{l}\text { Job/Function } \\
\text { Translator } \\
(25 \%)^{* *}\end{array}$ & $\begin{array}{l}\text { "thi girld is saying she } \\
\text { talks } 3 \text { languages and she is } \\
\text { proud of that becaused she } \\
\text { can say more and life is } \\
\text { esay for her. And it esay } \\
\text { she can talk } 3 \text { languges at } \\
\text { forst it was hard buta ll her } \\
\text { hard work paid up" }\end{array}$ & $\begin{array}{l}\text { "all the } \\
\text { opportunities I } \\
\text { have and the } \\
\text { benfits that can } \\
\text { help you in life } \\
\text { like in your jobs, } \\
\text { school" } \\
\text { "and you could go } \\
\text { to more places lke } \\
\text { towns and cities" }\end{array}$ \\
\hline $\begin{array}{l}\text { Appreciate } \\
\text { bilingual } \\
\text { programs in } \\
\text { our schools }\end{array}$ & $\begin{array}{l}\text { A5. Using } \\
\text { the strategies } \\
\text { from 'the } \\
\text { Bridge' has } \\
\text { helped me } \\
\text { better utilize } \\
\text { one language } \\
\text { to improve } \\
\text { my literacy in } \\
\text { the other } \\
(58 \%)^{*}\end{array}$ & $\begin{array}{l}\text { Setting in a } \\
\text { classroom } \\
(33 \%)^{* *}\end{array}$ & & $\begin{array}{l}\text { "For me it's the } \\
\text { only thing I'd ever } \\
\text { known [bilingual } \\
\text { education]. So it } \\
\text { feels weird to stop } \\
\text { learning Spanish } \\
\text { and to just go to } \\
\text { English, because } \\
\text { you always have } \\
\text { classes in both } \\
\text { languages" } \\
\text { "the cognates and } \\
\text { the } \\
\text { translanguaging I } \\
\text { have been doing } \\
\text { for a few years in } \\
\text { our elementary } \\
\text { school. And } \\
\text { sometimes I do it } \\
\text { automatically in } \\
\text { my head" }\end{array}$ \\
\hline
\end{tabular}

*Percentage of students that agree or highly agree with this statement.

**Percentage of students that included this trait in their drawing 
Tables 11 and 12 show a detailed breakdown of the occurrence of codes per theme in the students' narratives and in the focus group discussion.

\section{Table 11}

Occurrence of Codes Per Theme in Narratives

\begin{tabular}{|l|l|c|c|}
\hline \multicolumn{1}{|c|}{ Themes } & \multicolumn{1}{|c|}{ Codes } & $\begin{array}{c}\text { Occurrences } \\
\text { of Theme's } \\
\text { Codes }\end{array}$ & $\begin{array}{c}\text { \% of Overall } \\
\text { Code Occurrence } \\
(n=39)\end{array}$ \\
\hline $\begin{array}{l}\text { Acknowledge the positive role } \\
\text { of family }\end{array}$ & relationships $(n=6)$ & 6 & $15 \%$ \\
\hline $\begin{array}{l}\text { Develop confidence in } \\
\text { becoming biliterate }\end{array}$ & $\begin{array}{l}\text { monolingual vs bilingual }(n=9) \\
\text { personal identification }(n=2) \\
\text { language learner }(n=2)\end{array}$ & 13 & $33 \%$ \\
\hline $\begin{array}{l}\text { Appreciate using biliteracy } \\
\text { skills in the community }\end{array}$ & $\begin{array}{l}\text { relationships }(n=6) \\
\text { setting }(n=6)\end{array}$ & 12 & $31 \%$ \\
\hline $\begin{array}{l}\text { Envision the value of } \\
\text { biliteracy in their future }\end{array}$ & $\begin{array}{l}\text { biliterate }(n=7) \\
\text { strategies }(n=3)\end{array}$ & 10 & $26 \%$ \\
\hline $\begin{array}{l}\text { Appreciate bilingual programs } \\
\text { in our schools }\end{array}$ & language learner $(n=2)$ & 2 & $5 \%$ \\
\hline
\end{tabular}

\section{Table 12}

Occurrence of Codes Per Theme in Focus Group

\begin{tabular}{|c|c|c|c|}
\hline Themes & Codes & $\begin{array}{l}\text { Occurrences } \\
\text { of Theme's } \\
\text { Codes }\end{array}$ & $\begin{array}{c}\% \text { of Overall } \\
\text { Code Occurrence } \\
(n=69)\end{array}$ \\
\hline $\begin{array}{l}\text { Positive role of family in } \\
\text { developing biliteracy }\end{array}$ & $\begin{array}{l}\text { benefit }(n=5) \\
\text { family }(n=3)\end{array}$ & 8 & $12 \%$ \\
\hline $\begin{array}{l}\text { Confidence in becoming } \\
\text { biliterate }\end{array}$ & $\begin{array}{l}\text { biliteracy }(n=17) \\
\text { pride }(n=7) \\
\text { self-motivation }(n=9)\end{array}$ & 33 & $48 \%$ \\
\hline $\begin{array}{l}\text { Using biliteracy skills in the } \\
\text { community }\end{array}$ & $\begin{array}{l}\text { community }(n=7) \\
\text { cultural diversity }(n=1)\end{array}$ & 8 & $12 \%$ \\
\hline $\begin{array}{l}\text { Biliteracy valued for their } \\
\text { future }\end{array}$ & $\begin{array}{l}\text { professional career }(n=7) \\
\text { travel }(n=1)\end{array}$ & 8 & $12 \%$ \\
\hline $\begin{array}{l}\text { Appreciation of bilingual } \\
\text { programs in our schools }\end{array}$ & $\begin{array}{l}\text { biliteracy }(n=17) \\
\text { program structure }(n=10)\end{array}$ & 27 & $39 \%$ \\
\hline
\end{tabular}


Acknowledge the positive role of family. This theme of family refers to the person or persons that protect the student's rights particularly, in this study, to provide for education and live in a loving and supporting environment. When looking at the corpus data, students make some reference to a family member or people in their community that supports linguistic diversity. As shown in the previous analysis in section 1, and in Tables 7-10, students talk positively about their grandparents, parents, or the people they may assist in the community that finds difficult to communicate in English. In addition, students talk about the value their families give to develop biliteracy by providing books and access to education that helps students to see the positive value of becoming biliterate. It seems that what students say about their families is that they are the principal supporters of bilingual education. It is thanks to their families that they have access to a program that challenges their academic achievement in two-ways: content and language.

Develop confidence in becoming biliterate. This theme refers to the confidence with which students describe in speaking and writing their perception of what it means to them becoming biliterate. Becoming biliterate in this study refers to the ability that students must read and write at grade level in English and Spanish. The Oregon Department of Education establishes the proficiency levels for English language learners. A level-5 score in the English Language Proficiency Assessment for the $21^{\text {st }}$ Century signifies proficiency. For Spanish, it is required to score at intermediate high level in the American Council on the Teaching of Foreign Languages proficiency scale as provided by the Standard-Based Measure of Proficiency assessment. The corpus data shows that students are confident about becoming biliterate by talking about reading books in two 
languages, writing papers in both languages, and exhibiting confidence when doing academic presentations in front of an audience. In addition, students can describe the challenges that monolingual speakers face in the community, and how their biliterate skills give them the advantage to support them. Furthermore, students can talk about instructional strategies that only bilingual students are exposed to in the educational environment like code-mixing, translanguaging, using one language to explain another one, the Bridge, and recognition of cognates.

Appreciate using biliteracy skills in the community. This theme refers to the students and their ability to use their reading and writing skills in addition to their speaking and understanding of two languages for the service of the community. The corpus data provided evidence to support this claim by students talking about translating for different situations for their families, like the one where an aunt had a car accident. Because she was in a nervous scenario, she could not speak or understand anything that was happening around her, and one of the students helped to translate for her. Another student talks about helping others to order food in a restaurant. It seems that although students' examples are concrete to their age, the empathy developed in addition to their biliteracy is even one more response to students developing of biliteracy in the classroom. Their view on caring for others seems to be wider because their ability to support extends to more linguistically diverse people.

Envision the value of biliteracy in their future. Future, in this theme, refers to the college and career readiness for all students. Attending a K-6 grades school in a bilingual education program seems to influence students' vision of their future career. At 
this young age, students are cared for and they should only be focused on how to be happy and learn. Therefore, it seems that the positive influence of bilingual adults in their lives have shown them that the benefits of their future careers may be enriched by the fact that they are already bilingual and biliterate. In addition, if they choose to continue 7-12 grades in the dual language program, they may be awarded the Oregon Seal of Biliteracy attached to their high school diploma, which provides advantages described in Appendix P, by the Oregon Department of Education (2016b).

Appreciate bilingual programs in our schools. This theme refers to the appreciation for a bilingual education program. I defined appreciation as the academic and personal value that students give to a program that promotes learning in two languages. Students from this program might have choices. They could choose to be in a summa/excel or a general education program. As explained in Chapter 1, a bilingual program provides students with the opportunity to learn content and language in a gradual program going from $90 / 10$ in the first years to $50 / 50$ in the secondary years. This appreciation is worth mentioning because, in my own experience, studying in a language that is not one's own dominant language or the dominant language in the environment, presents additional challenges that otherwise would not exist and the focus would be to learn content and improve one language, instead of learning and perfecting two linguistic systems with their own conventions and rules. Students seemed to realize those challenges when they talked about their previous experiences in a dual language/immersion program. In addition, some of the students in this study have been in a dual language program since kindergarten and they seem to admit that this is the one 
program they know and that they would like to continue for as long as they can. Finally, some students want to really become biliterate, so they are involved in their classes and on the question of how they can improve both English and Spanish.

\section{Limitations}

The growing research in the field of bilingual education shows the growing demand of students in the U.S. schools that are simultaneous bilinguals. Research from Beeman and Urow (2013), Collier and Thomas (2009), Escamilla et al. (2014), O. García et al. (2017), among other researchers, indicates that there are many approaches to better supporting simultaneous bilinguals in U.S. schools. The present study intends to add to the conversation of bilingual education studies that support biliteracy for simultaneous bilinguals at the secondary level. Furthermore, it is ethical to recognize the limitations in which this study took place. While the analysis is in depth, the data was collected in a period of three months, in my classroom, with students that have had a maximum of five years of bilingual education in an elementary level. In addition, simultaneous bilinguals are becoming "the new normal" (Escamilla et. al. 2014, p. xi) in U.S. schools and with the influence of globalization, more of these simultaneous bilinguals speak and understand more than two languages and they need to study more than only humanities. In other words, this study in combination with the growing literature might offer an additional perspective in how students respond to the multiple approaches to develop biliteracy, however, the previously mentioned limitations validate Yin's (2016) explanation: "the study may call for collecting an intensive amount of data about the same setting" (p. 218). 


\section{Conclusion}

This chapter presented the analysis, presentation, and interpretation of the data collected over a period of three months. The findings from this case study may be "used to apply in other situations or cases" (Yin, 2016, p. 83). Bandura (1986) explained that his triatic reciprocal causation implies that, we as humans will learn from what others say and do and that we will not want to learn by trial and error how to climb a rock. Similarly, this chapter is presenting the findings of how students respond to developing biliteracy. Teachers, parents, administrators and organizations look for the positive responses to learning from students. This chapter analyzed five different instruments that showed how students develop biliteracy. The findings show that the motivation of the students and the support from family and community play a role in the feelings that the students develop to learn in a bilingual program and develop biliteracy. In addition, students value the promise benefits in their future career as confident biliterate and bilingual individuals. 


\section{Chapter 5: Discussion and Conclusion}

The purpose of this study was to explore how simultaneous bilingual middle school students respond to becoming biliterate in Spanish and English as a result of participation in a humanities dual language/immersion class, taught through the instructional strategy the Bridge. This study will add to the growing literature in bilingual education and furthermore to the discussion on how to better capitalize on the already bilingual skills of the multicultural students in U.S. classrooms. This study provides an insight into the responses from the students. While a group of dedicated researchers cited throughout this study has contributed to improving bilingual programs, not much was done to study students' responses to all those strategies to advance their personal views. As Gardner and Lambert (1972) worked to understand how some individuals were successful in learning a world language and some were not, I now look into how simultaneous bilinguals develop biliteracy and how their personal beliefs and the influence of the environment promote attainment of bilingualism and biliteracy.

In this section, I will first discuss the major findings of the study, its implications and the promise of the Bridge to advance biliteracy, and finally future research.

\section{Synthesis of Findings}

As a result of my study, I gain the following insights that may be transferable and if combined with other studies may provide support for simultaneous bilinguals to develop biliteracy: 
1. Simultaneous bilingual middle school students demonstrate consistently through classroom activities, survey, drawing, narrative, and focus group discussion that they are intrinsically motivated to become biliterate;

2. Students seemed to have learned a variety of strategies like code-switching, cognate recognition, translanguaging, and use one language to explain the other, during their participation in lessons with the Bridge instructional strategy;

3. Students acknowledge their use of their bilingual and biliterate skills in their communities, their homes, and their school that reinforces their biliteracy;

4. Students recognize how they can contribute to the community and provide help to those that need to communicate and do not have the linguistic skills.

5. It seems to me that becoming biliterate and using those skills in the community forms the basis for an empathetic understanding of others.

First, students demonstrated that their motivation to become biliterate relies on their own motivation supported by their families and the community. Simultaneous bilingual middle school students demonstrate consistently through classroom activities, survey, drawing, narrative, and focus group discussion that becoming biliterate requires intrinsic motivation. Presented in Chapter 4, the analysis of the corpus data demonstrated that students personally pursue becoming biliterate. Bilingual students may have school program choices, one of them being the dual language/immersion programs and given the value from the community and the support from their families, students want to achieve higher levels of biliteracy in these programs.

Second, students seem to recognize strategies that relate to bilingual students to help them advance academically in two languages compared to monolingual students. After exposure to the Bridge simultaneous bilingual middle school students have the knowledge to talk about the instructional strategies that help them develop biliteracy. They are able to explain that to be bilingual, a person not only can speak and understand 
two languages but must also have reading and writing skills. Students can describe what are cognates, how they use one language to explain the other, how they code-switch using both languages simultaneously to communicate a message, or how the skills they learn in one language, can be "Bridged" to the other language without going through the same lesson in both languages.

Third, students expressed that it is useful for them to be bilingual because they help their families to communicate where English is needed. One example was the student who translated for his aunt in a car accident.

Fourth, students help people in their community that have not develop the linguistic abilities to meet their communication needs.

Finally, students demonstrated that through developing bilingual and biliteracy skills, they had developed a greater sense of empathy. Students recognize how they can contribute to the community and provide help to those who need to communicate and do not have the linguistic skills. Simultaneous bilinguals are aware of their advantages and the privilege to have access to bilingual programs and are not shy about lending a hand to those who have not had the opportunity to learn the languages they already speak, understand, read, write, and have cultural awareness in.

\section{Implications of the Instructional Strategy the Bridge to Advance Biliteracy}

The research question for my study was: How do simultaneous bilingual middle school students respond to becoming biliterate when taught using the Bridge strategy in a humanities dual language/immersion class? 
The theoretical framework I used to respond to this question was the "triadic reciprocal causation" of Bandura's (1986) social cognitive theory. Bandura's theory, as explained in Chapter 2, explains that people are "a producer [and] a product of their environment" (p. 24). People's, in this case simultaneous bilingual middle school students', beliefs and values "influence how they behave" (p. 24). In turn, simultaneous bilingual middle school students" "behavior elicits reactions which in turn can alter the course of behavior" (p. 24). In other words, students' beliefs and values about becoming biliterate change their actions, consequently they are developing biliteracy, and this again may impact the environment, for example create equity and acceptance of diversity, for example in terms of cultures, religion, race, gender, and values. The social cognitive theory lent a framework to answer the sub-questions of this study when the goal of the instructional strategy in the classroom is to develop biliteracy as taught through the Bridge instructional strategy.

\section{The Bridge as Instructional Strategy}

The instructional strategy the Bridge seems to make it easier for students to compare and connect between the languages they are learning. In addition, this instructional strategy strengthened the academic content that students need at this grade level and seemed to make the best use of time for students to advance literacy in two languages. Furthermore, the students' experience in the classroom using the Bridge instructional strategy allowed students to grow more confident, proud, and self-motivated to become biliterate. 


\section{Recommendations}

I would like to suggest that this work will be furthered by additional research. It seems that research in the following areas would add significantly to our understanding of developing programs that support advancing biliteracy skills of our younger students. In addition, it is important for the people in the United States to think about adding to the strength of our democracy by having many more young people who love and appreciate their ability to speak and understand more than one language, more than one culture and an open mind to world perspectives. In the following section are some suggestions for different stakeholders.

For policymakers. To support and expand high-quality dual language programs in elementary and secondary schools. In addition, promote more programs to scale bilingual programs to less common languages. Furthermore, establish best practices and policies for departments of education to support the biliteracy of young people.

For universities. There are two opportunities I see for universities to support bilingual teachers: (1) Bilingual Path College Programs identifying and working collaboratively with world language and literatures departments to identify fluent speakers and potential candidates for education; and (2) Supporting already bilingual teachers via secondary certification in the school districts to teach at advanced middle and high school level science, math, social studies, and language arts. In addition, universities may explore how we can increase the availability of licensed quality bilingual teachers. 
For teachers. More support for already bilingual teachers in the schools via secondary certification. In addition, teachers should have more support to seek opportunities to study abroad and improve their pedagogical and linguistic skills. Furthermore, teachers of simultaneous bilingual students should possess an additional set of skills to understand and support their simultaneous or multilingual students. These students have unique challenges because they think in two or more languages including linguistic differences. Teachers can also research more on particular strategies designed to further biliteracy, such as the Bridge.

For advocates. More secondary programs (middle school and high school) that support students' acquisition of biliteracy. There is a need to continue developing biliteracy in content areas such as, science, math, social sciences, and humanities at the secondary level to improve biliteracy. In addition, provide support for teachers to face the different challenges and opportunities when teaching in dual language schools.

Furthermore, it will benefit to make mandatory to have a world language class from K-12 education.

\section{Future Research}

Students are intrinsically motivated to learn another language. According to the social cognitive theory (Bandura, 1986) the influence of the environment (students' family and school environment) provide the medium for students to continue developing their biliteracy and for students to see the value of their language skills. I hope that future education policy will better reflect the reality of the theory and research into biliteracy 
and bilingualism to prepare students better for the globalized and multilingual world we live in.

More research is needed on:

- $\quad$ best practices to reach out to communities and families to nurture and maintain their heritage languages.

- $\quad$ building strong programs to support our simultaneous bilingual students as they become biliterate and use the language foundation from their families and culture.

- the equity impact of bilingual education.

- the question how the non-bilingual school community's ability to understand and support bilingual students can help students' academic success.

- the problem how to accurately assess bilinguals'/ biliterates' academic skills, so that students are appropriately supported.

- $\quad$ improving dual language programs and students' biliteracy to meet international standards.

- developing opportunities for the students to further develop linguistic skills that apply to engineering, science, and technology using both languages.

\section{Impact of the Study}

It has been important for me to share the importance of the Bridge at the secondary level with other colleagues. Standardized tests are in English, therefore, it is necessary that students develop bilingual skills to communicate their ideas. I shared the preliminary results of this study at the Oregon Association of Bilingual Education 
(OABE) Conference 2019. I have also conducted a professional development workshop focused on math and science to model the Bridge in my school district. 


\section{References}

Aguirre, F. P. (2005). Mendez v. Westminster School District: How It Affected Brown v. Board of Education. Journal of Hispanic Higher Education, 4(4), 321-332. Retrevied from https://doi.org/10.1177/1538192705279406

Andrade, C., \& Ging, D. (1988). Urban FLES models: Progress and promise. In J. F. Lalande (Ed.), Shaping the future of language education: FLES, articulation, and proficiency. Report of central states conference on the teaching of foreign language (pp. 63-81). Washington, DC: Educational Resources Information Center (ERIC).

Attride-Stirling, J. (2001). Thematic networks: An analytic tool for qualitative research. Qualitative Research, 1(3), 385-405.

Aukerman, M., Schuldt, L. C., Aiello, L., \& Martin, P. C. (2017). What meaning-making means among us: The intercomprehending of emergent bilinguals in small-group text discussions. Harvard Educational Review, 87(4), 482-511.

Baker, C., \& Wright, W. E. (2017). Foundations of bilingual education and bilingualism (6th ed.). Bristol, UK: Channel View Publications/Multilingual Matters.

Baker, R. E. (1978). Futurism and foreign languages: Reaching toward tomorrow-The 1978 Central States Conference. Modern Language Journal, 62(5-6), 262-266.

Bandura, A. (1986). Social foundations of thought and action: A social cognitive theory. Englewood Cliffs, NJ: Prentice-Hall.

Beeman, K., \& Urow, C. (2013). Teaching for biliteracy: Strengthening bridges between languages. Philadelphia, PA: Caslon.

Bialystok, E., \& Hakuta, K. (1994). In other words: The science and psychology of second-language acquisition. New York, NY: Basic Books Perseus Books Group.

Calkins, L., Fell, S. \& Marron, A. (2014). Personal narrative: Crafting powerful life stories. Portsmouth, NH: Heinemann.

Carlo, M. S., August, D., McLaughlin, B., Snow, C. E., Dressler, C., Lippman, D. N., ... White, C. E. (2004). Closing the gap: Addressing the vocabulary needs of English-language learners in bilingual and mainstream classrooms. Reading Research Quarterly, 39(2), 188-215. 
Chambers, D. W. (1983). Stereotypic images of the scientist: The draw-a-scientist test. Science Education, 67(2), 255-265.

Colby, S. L., \& Ortman, J. M. (2014). Projections of the size and composition of the U.S. population: 2014 to 2060. Retrieved from https:/www.census.gov/content/dam/ Census/library/publications/2015/demo/p25-1143.pdf

Collier, V. P., \& Thomas, W. P. (2009). Educating English learners for a transformed world. Albuquerque, NM: Dual Language Education of New Mexico/Fuente Press.

Corona, R., Stevens, L. F., Halfond, R. W., Shaffer, C. M., Reid-Quiñones, K., \& Gonzalez, T. (2012). A qualitative analysis of what Latino parents and adolescents think and feel about language brokering. Journal of Child and Family Studies, 21(5), 788-798. https://doi.org/10.1007/s10826-011-9536-2

Creswell, J. W. (1998). Qualitative inquiry and research design: Choosing among five traditions. Thousand Oaks, CA: SAGE.

Cummins, J. (2018). Foreword. In G. Valdés, K. Menken, \& M. Castro (Eds.), Common core bilingual and English language learners: A resource for educators (pp. ix-x). Philadelphia, PA: Caslon.

Curtain, H. (1990). Foreign language learning: An early start. Washington, DC: ERIC Clearinghouse on Languages and Linguistics.

D’Adamo, F. (2003). Iqbal (A. Leonori, Trans.). United States of America: Aladdin Paperbacks. (Original work published 2001)

Daniel, S. M., \& Pacheco, M. B. (2016). Translanguaging practices and perspectives of four multilingual teens. Journal of Adolescent and Adult Literacy, 59(6), 653663.

Davidson, F. W. (Producer), \& Davidson, J. M. (Director) (2013). Bandura's Social Cognitive Theory: An Introduction [Motion picture]. United States: Davidson Films, Inc.

Decker, S. (2017). U.S. education in 2017 in 10 charts-Education Week. Education Week. Retrieved from https://www.edweek.org/ew/section/multimedia/useducation-in-2017-in-10-charts.html

Dressler, C., Carlo, M. S., Snow, C. E., August, D., \& White, C. E. (2011). Spanishspeaking students' use of cognate knowledge to infer the meaning of English words. Bilingualism: Language and Cognition, 14(2), 243-255. 
Duty, S. (2016). The impact of Daily 5 and CAFÉ Literacy framework on reading comprehension in struggling fourth grade readers: A case study (Doctoral dissertation). Available from ProQuest Dissertations and Theses database. Retrieved from http://search.proquest.com/docview/1777617032/

Escamilla, K., Hopewell, S., Butvilofsky, S., Sparrow, W., Soltero-González, L., RuizFigueroa, O., \& Escamilla, M. (2014). Biliteracy from the start: Literacy squared in action. Philadelphia, PA: Caslon.

Gándara, P., \& Escamilla, K. (2017). Bilingual education in the United States. In O. Garcia, A. Lin \& S. May (Eds.), Bilingual and multilingual education (pp. 1-14). Springer, Cham. Retrieved from https://doi.org/10.1007/978-3-319-02324-3_33-2

García, G. E., \& Godina, H. (2017). A window into bilingual reading: The bilingual reading practices of fourth-grade, Mexican American children who are emergent bilinguals. Journal of Literacy Research, 49(2), 273-301.

García, O., Johnson, S. I., \& Seltzer, K. (2017). The translanguaging classroom: Leveraging student bilingualism for learning. Philadelphia, PA: Caslon.

García, O., \& Kleifgen, J. A. (2018). Educating emergent bilinguals: Policies, programs, and practices for English learners (2nd ed.). New York, NY: Teachers College, Columbia University.

Gardner, R. C. \& Lambert, W. E. (1972). Attitudes and motivation in second-language learning. Rowley, MA: Newbury House Publishers.

Gibson, C. (2016). Bridging English language learner achievement gaps through effective vocabulary development strategies. English Language Teaching, 9(9), 134-138.

Glesne, C. (2016). Becoming qualitative researchers: An introduction (5th ed.). Boston, MA: Pearson.

Goodenough, F. L. (1926). Measurement of intelligence by drawings. New York, NY: Harcourt Brace.

Hamayan, E. V. (1986). The need for foreign language competence in the United States. Washington, DC: Center for Applied Linguistics.

Harmon, J., Antuna, M., Juarez, L., Wood, K. D., \& Vintinner, J. (2018). An investigation of high school social studies teachers' understandings of vocabulary teaching and learning. Reading Psychology, 39(3), 271-302.

Heining-Boynton, A. L. (1990). Using FLES history to plan for the present and future. Foreign Language Annals, 23(6), 503-510. 
Jiménez, F. (2000). Cajas de cartón (F. Jiménez, Trans.). United States of America: Houghton Mifflin Harcourt. (Original work published 1997)

Jimenez, R. T., Garcia, G. E., \& Pearson, P. D. (1995). Three children, two languages, and strategic reading: Case studies in bilingual/monolingual reading. American Educational Research Journal, 32(1), 67-97.

Kleyn, T., López, D., \& Makar, C. (2015). “What about bilingualism?” A critical reflection on the edTPA with teachers of emergent bilinguals. Bilingual Research Journal, 38(1), 88-106.

Koda, K., \& Zehler, A. M. (Eds.). (2008). Learning to read across languages: Crosslinguistic relationships in first- and second-language literacy development. New York, NY: Routledge.

Krathwohl, D. R. (2009). Methods of educational and social science research: The logic of methods (3rd ed.). Long Grove, IL: Waveland Press.

Levin, B. (1982). The making (and unmaking) of a civil rights regulation: Language cinority children and bilingual education (Project Report No. 82A4.

Stanford, CA: Stanford University Institute for Research on Educational Finance and Governance.

Maxwell, J. A. (2013). Qualitative research design: An interactive approach (3rd ed.). Thousand Oaks, CA: Sage.

McFarland, J., Hussar, B., de Brey, C., Snyder, T., Wang, X., Wilkinson-Flicker, S., ... Hinz, S. (2017). The condition of education 2017. NCES 2017-144. National Center for Education Statistics. Retrieved from: http://nces.ed.gov/

Merriam, S. B. (2009). Qualitative research: A guide to design and implementation. San Francisco, CA: Jossey-Bass.

Miles, M. B., \& Huberman, A. M. (1984). Qualitative data analysis: A sourcebook of new methods. Beverly Hills, CA: Sage.

Modern Language Association. (2010). Most spoken languages in Oregon in 2010. Retrieved from https://apps.mla.org/map_data

Montrul, S. (2013). El Bilingüismo en el Mundo Hispanohablante. Singapore: WileyBlackwell.

Moulton, W. G. (1962). The sounds of English and German. Chicago, IL: University of Chicago Press. 
O’Connor, R. E., Beach, K. D., Sanchez, V. M., Bocian, K. M., \& Flynn, L. J. (2015). Building BRIDGES: A design experiment to improve reading and United States history knowledge of poor readers in eighth grade. Exceptional Children, 81(4), 399-425.

Oregon Department of Education (2014a). Two-Way Immersion/Dual Language Programs. Presentation to the State Board of Education. Retrieved from https://www.oregon.gov/ode/about-us/stateboard/Documents/October\%20 2014\%20board\%20meeting/two-way-immersiondual-language-programs.pdf

Oregon Department of Education (2014b). Bilingual teachers-Survey results. Retrieved from https://www.oregon.gov/ode/aboutus/stateboard/Documents/December\%202014\%20Board\%20Materials/bilingualteachers- $\%$ E2\%80\%93-survey-results.pdf

Oregon Department of Education (2016a). English Learners Program Guide. Retrieved from https://www.oregon.gov/ode/students-and-family/SpecialEducation/ RegPrograms_BestPractice/Documents/englishlearnerprogramguide2016-17.pdf

Oregon Department of Education. (2016b). Oregon State Seal of Biliteracy. Retrieved from https://www.oregon.gov/ode/students-and-family/equity/EngLearners/ Documents/BiliteracySealOnePager.pdf

Park, M., Zong, J., \& Batalova, J. (2018). Growing superdiversity among young U.S. dual language learners and its implications. Retrieved from https://www. migrationpolicy.org/research/growing-superdiversity-among-young-us-duallanguage-learners-and-its-implications

Powell, M. B., \& Snow, P. C. (2007). Guide to questioning children during the free narrative phase of an investigative interview. Australian Psychologist, 42(1), $57-65$.

Rhodes, N. (1991). The status of elementary school language programs. In M. Rosenbusch \& D. Kremer (Eds.), Colloquium on foreign languages in the elementary school curriculum: Proceedings (pp. 37-40). New York, NY: American Association of Teachers of German.

Rosenbusch, M. H. (2012). US foreign-language teaching in kindergarten to 12th grade. In C. C. Chapelle (Ed.), The encyclopedia of applied linguistics (pp. 5985-5991). Chichester, West Sussex, UK: Wiley-Blackwell. doi: 10.1002/9781405198431.wbeal0424

Saldaña, J. (2009). The coding manual for qualitative researchers. Chippenham, Wiltshire: Sage. 
Sanchez, C. (2017). English language learners: How your state is doing. Retrieved from https://www.npr.org/sections/ed/2017/02/23/512451228/5-million-englishlanguage-learners-a-vast-pool-of-talent-at-risk

Seidman, I. (2013). Interviewing as qualitative research: A guide for researchers in education and the social sciences. New York, NY: Teachers College Press.

Smith, B. E., Pacheco, M. B., \& de Almeida, C. R. (2017). Multimodal codemeshing: Bilingual adolescents' processes composing across modes and languages. Journal of Second Language Writing, 36, 6-22.

Symons, C., Palincsar, A. S., \& Schleppegrell, M. J. (2017). Fourth-grade emergent bilinguals' uses of functional grammar analysis to talk about text. Learning and Instruction, 52, 102-111.

Thomas, W. P., \& Collier, V. P. (2012). Dual language education for a transformed world. Albuquerque, NM: Dual Language Education of New Mexico/Fuente Press.

U.S. Census Bureau. (2014). US population by nativity: 2014 to 2060. Retrieved from https://www.census.gov/data/tables/2014/demo/popproj/2014-summarytables.html

U.S. Census Bureau. (2015a). Census Bureau reports at least 350 languages spoken in U.S. homes [Press Release]. Retrieved from https://www.census.gov/newsroom/ press-releases/2015/cb15-185.html

U.S. Census Bureau. (2015b). Number of languages spoken in the 15 largest metro areas. Retrieved from https://www.census.gov/content/dam/Census/newsroom/ releases/2015/cb15-185_graphic.pdf

Valdés, G., Menken, K., \& Castro, M. (Eds.). (2015). Common core bilingual and English language learners: A resource for educators. Philadelphia, PA: Caslon.

Vásquez, A., Hansen, A., \& Smith, P. C. (2013). Teaching language arts to English language learners. New York, NY: Routledge.

Wei, L. (Ed.). (2010). Bilingualism and multilingualism: Critical concepts in linguistics (Vol. I). New York, NY: Routledge.

Woodrich, M., \& Fan, Y. (2017). Google Docs as a tool for collaborative writing in the middle school classroom. Journal of Information Technology Education:

Research, 16, 391-410.

Yin, R. K. (2016). Qualitative research from start to finish (2nd ed.). New York, NY: The Guilford Press. 
Appendix A: Verbal Recruitment Script 


\section{Verbal Recruitment Script}

Verbal Recruitment Script to be Used to Recruit Participants to Conduct the Study: "Emergent Bilingual Middle School Students: Responses to 'the Bridge' between Two Languages in a Humanities Dual Language Immersion Class."

Dear Dual Language Families,

¡Welcome to Middle School! I am Lucinda Philipp, and I will be your student's Dual Language Humanities teacher this year.

A truly bilingual individual is literate in two languages and to achieve this goal, a bilingual program might implement the Bridge technique to advance student's literacy in both English and Spanish. Besides a teacher, I am also a researcher at Portland State University. This year I would like to conduct a study on a dual language strategy called "the Bridge," authored by Karen Beeman and Cheryl Urow (2013). The title of the study is "Simultaneous Bilingual Middle School Students: Responses to 'the Bridge' between Two Languages in a Humanities Dual Language Immersion Class." The purpose of the study is to explore how emergent bilingual middle school students respond to becoming bilingual as a result of participation in "The Bridge" between the two languages in a humanities dual language/immersion class. The research question is: How do emergent bilingual middle school students respond to the "Bridge" instructional strategy between two languages in a humanities dual language/immersion class?

At the end of this study, I hope to learn how students respond to the Bridge strategy and to understand better what factors increase students' success in these classes to advance the field of bilingual education at the middle school level.

To give you some background of the study, I like to mention that the increasing number of students with diverse linguistic and cultural backgrounds, often called "simultaneous bilinguals," at all grade levels, is increasing. My own family is a mix of three cultures: German, Mexican and American. One instructional strategy that seems promising is "the Bridge" where students contrast and connect the literacy skills learned in one language to the literacy skills in their other language, which in turn seems to make them better in both languages. Your child is invited as a possible participant in this study because your child has had at least three years of bilingual education, this means that your child has basic knowledge of English and Spanish languages and your child is enrolled in the middle school dual language immersion program, here at Middle School. If you decide to allow your child to participate, there will be five activities: 1) regular lessons for class framed with the Bridge; 2) a survey; 3 ) a focus group interview; 4) a drawing; and, 5) a narrative. All the activities will take place here in this room; the humanities classroom room B-10 at Middle School over a period of six to eight-week during September through December 2018 for all the lessons. The drawing and the free- 
narrative will take place during the class time during the study. A survey and a focus group interviews will take place in the classroom after students have used "the Bridge" learning strategy in class. Survey and focus group discussion will be recorded and transcribed in written form for analysis, and it will take place after regular school hours.

Our Teacher on Special Assignment for the Dual Language Program from the Multilingual Department will come in to help me facilitate the focus group. The survey will take place during the class time during the study.

There are few risks, discomforts, or inconveniences from this study. I will minimize those risks by keeping the data collected confidential and not using your child's name in any results that are found. There are no costs involved to participate in this study. The study will help students contrast and make connections between Spanish and English to help them acquire biliteracy: this means that students will become proficient in reading, writing, listening, and speaking skills in both languages. The study will also help teachers to understand how "the Bridge" strategy supports the acquisition of biliteracy in the humanities class.

Any information obtained relating to this study, and that can be identified with your child will remain confidential and will be disclosed only with your permission. Subject identities will be kept confidential by using pseudonyms in the study. Data from the study will be locked in a file cabinet, and electronic information will be password protected.

Your child's participation is voluntary. Your decision whether or not to allow your child to participate will not affect you or your child's relationship with my class or myself, as a teacher at Middle School. If you decide not to allow your child to participate once the study began, you and/or your child are free to withdraw your consent and discontinue participation at any time without penalty.

If you have any questions about the study, please feel free to contact me here at Middle School or send me an email. My email is in the letter I am providing today. My advisor at Portland State University is Dr. Dannelle D. Stevens. Her email is in the letter as well. If you have questions regarding your rights as a research subject, please contact the Institutional Review Board - IRB- at Portland State University. You will be offered a copy of this form to keep.

I will give you these two forms: a letter for you and a letter for your student. I appreciate your consent for my study. Please, also talk with your student at home and share with them your opinion about their participation in my research. I will pass the letter to them in class. If you allow me to use your students' assignments and work from lessons with the Bridge strategy done in class, as well as to let them participate one day in November after school for the focus group, please sign the letter. Your signature in that letter indicates that you have read and understood the information in the letter and what I have just shared with you and that you freely agree to allow your child to participate in my study. Your signature also means that you understand that you and your student may 
withdraw your consent and permission at any time and discontinue participation without penalty.

Please, talk with your student at home about this study. I will appreciate your support to help me learn more about the Bridge and how to improve even more our Dual Language classes here at Middle School as well as in the field of Bilingual Education. 
Appendix B: Guion Para Reclutamiento de Candidatos Para Estudio 


\section{Guión para Reclutamiento de Candidatos para Estudio}

Guion que se utilizará para reclutar participantes para llevar a cabo el estudio:

"Estudiantes bilingües simultáneos de escuela intermedia: respuesta a la estrategia de enseñanza "el Puente" entre dos idiomas en una clase de inmersión de lenguaje dual en la clase de Humanidades".

Estimadas familias:

¡Bienvenidos a Middle School! Soy Lucinda Philipp, seré la maestra de humanidades del programa dual este año.

Una persona verdaderamente bilingüe sabe leer y escribir en dos idiomas y para lograr este objetivo, un programa bilingüe se beneficia de implementar la estrategia de enseñanza "el Puente" para avanzar en la alfabetización de los estudiantes tanto en inglés como en español, de ahí que se llama "el Puente". Además de ser maestra, también soy investigadora de Portland State University, la Universidad Estatal de Portland. Este año voy a realizar un estudio sobre una estrategia de enseñanza en clases de lenguaje dual llamada "El Puente", escrita por Karen Beeman y Cheryl Urow en el 2013. El título del estudio es "Estudiantes Simultáneos Bilingües de la Escuela Secundaria: Respuestas al 'puente' entre dos idiomas en una clase de inmersión dual en Humanidades". El propósito del estudio es explorar cómo responden los estudiantes bilingües de escuela intermedia a su bilingüismo como resultado de la participación en "el Puente", la conexión y comparación entre los dos idiomas en mi clase de doble inmersión de humanidades. La pregunta de investigación es: ¿Cómo responden los estudiantes bilingües de escuela intermedia a la estrategia educativa "Puente" entre dos idiomas en una clase de lenguaje dual de inmersión en humanidades?

Al final de este estudio, espero aprender cómo los estudiantes responden académicamente y personalmente a la estrategia y comprender mejor los factores que aumentan el éxito de los estudiantes en estas clases. Además, los resultados del estudio ayudarán al crecimiento de la investigación en el campo de la educación bilingüe en la escuela intermedia.

Para darles un poco de antecedentes sobre el estudio, me gustaría mencionar que los estudiantes de herencia cultural diversa en nuestras escuelas ahora también llamados "bilingües simultaneos", en todos los grados, va en aumento. Mi propia familia es una mezcla de tres culturas: alemana, mexicana y estadounidense. Una estrategia instructiva que parece prometedora es "el puente", donde los estudiantes contrastan y conectan las habilidades de lectoescritura aprendidas en un idioma con las habilidades de lectoescritura en el otro idioma, lo que a su vez les ayuda a aprender en ambos idiomas. Invito a su hijo o hija a participar como posible candidato en este estudio porque su hijo o hija ha tenido al menos tres años de educación bilingüe, esto significa que su hijo tiene conocimientos esenciales del inglés y del español. Además, su hijo está inscrito en el programa de inmersión dual aquí en Middle School. Si decidiera permitir 
que su hijo o hija participe, las actividades que harán son cinco: 1) participar en las lecciones, que de cualquier manera recibirán los beneficios ya que las unidades de la escuela están estructuradas bajo el marco teórico de "el Puente"; 2) responder una encuesta; 3) hacer un dibujo de un estudiante bilingüe; 4) escribir la descripción de su dibujo; y 5) participar en un grupo de discusión. Las actividades se llevarán acabo aquí en el salón de humanidades B-10 en Middle School. El estudio durará de seis a ocho semanas y tendrá lugar durante los meses de septiembre a diciembre de 2018 para todas las lecciones. La ilustración y la narración libre tendrán lugar durante el tiempo de clase durante el estudio. La encuesta y el grupo de discusión serán en el salón después de que los alumnos hayan utilizado la estrategia de aprendizaje de idiomas "Puente". El grupo de discusión se grabará y se transcribirá para su análisis. Estas dos actividades serán después del horario escolar regular.

Nuestra maestra en asignación especial para el programa bilingüe del Departamento multilingüe vendrá para facilitar el grupo de discusión. La encuesta se llevará a cabo durante el tiempo de clase durante el estudio.

Hay pocos riesgos, incomodidades o inconvenientes con este estudio. Minimizaré esos riesgos al mantener la información recopilada confidencial y no usar el nombre de su hijo en los resultados que se encuentran. No hay ningún costo por participar en este estudio. El estudio ayudará a los estudiantes a comparar y hacer conexiones entre el español y el inglés para ayudarlos a adquirir la lectoescritura bilingüe: esto significa que los estudiantes adquirirán destrezas de lectura, escritura, comprensión oral y expresión oral en ambos idiomas. El estudio también ayudará a otros maestros a entender cómo la estrategia "Puente" apoya la adquisición de alfabetización bilingüe.

Cualquier información que se obtenga relacionada con este estudio y que se pueda identificar con su hijo se mantendrá confidencial y se divulgará solo con su permiso o según lo exija la ley. Las identidades de los estudiantes se mantendrán confidenciales mediante el uso de seudónimos en el estudio. Los datos del estudio se guardarán en un archivador y la información electrónica estará protegida por contraseña.

La participación de su hijo o hija es voluntaria. Su decisión de permitir que su hijo o hija participe o no le afectará a usted o a la relación de su hijo con mi clase o conmigo, como maestra en Middle School. Si decide no permitir que su hijo participe una vez que haya comenzado el estudio, usted y / o su hija o hijo son libres de retirar su consentimiento y descontinuar la participación en cualquier momento sin penalización.

Si tiene alguna pregunta sobre el estudio, no dude en ponerse en contacto conmigo en mi correo electrónico de Middle School. Mi asesora en la Universidad Estatal de Portland es la Dra. Dannelle D. Stevens. Su correo electrónico está en la carta que les daré hoy para su consideración. Si tiene preguntas sobre sus derechos como sujeto de investigación, comuníquese con la Junta de Revisión Institucional de Portland State University y del Distrito. 
Le daré estos dos formularios: una carta para usted y una carta para su estudiante. Le agradeceré su consentimiento. Por favor, también hable con su estudiante en casa y comparta con ellos su opinión sobre su participación en mi estudio. Les pasaré la carta en clase. Si me permite usar las tareas y el trabajo de los alumnos en clase, así como dejar que participe un día de noviembre después de la escuela para el grupo de discusión, firme la carta y entréguemela por favor. Su firma en esa carta indica que ha leído y entendido la información de la carta y lo que acabo de compartir con usted y que acepta libremente que su estudiante participe en mi estudio. Su firma también significa que usted y su estudiante saben que tienen libertad para retirar su consentimiento en cualquier momento y descontinuar la participación sin penalidad.

Por favor, hable con su estudiante sobre este estudio. Apreciaré su apoyo para ayudarme a mejorar aún más nuestras clases de Lenguaje Dual aquí en School, así como en el campo de la Educación Bilingüe. 
Appendix C: Student Assent Form 


\section{Student Assent Form}

\section{Simultaneous Bilingual Middle School Students: Responses to "the Bridge" Strategy between Two Languages in a Humanities Dual Language Immersion Class}

I am willing to participate in the study called "Simultaneous Bilingual Middle School Students: Responses to "the Bridge" Strategy between Two Languages in a Humanities Dual Language Immersion Class".

I understand that Sra. Philipp, who is my teacher and also a researcher from Portland State University, wants to learn about what I think about being a bilingual student. My teacher would like to learn from me so that she can be a better teacher.

To understand more about my being a bilingual student, my teacher will collect five different kinds of information.

1. Samples assignments from my work using the Bridge strategy.

2. The results from a survey about how I think about learning another language.

3. My drawing of a bilingual student

4. A written description of my drawing

I understand that all of the above information will be collected during class time.

5. A transcript of what I say in a small group discussion, called a focus group.

I understand that only a small group of six to eight students will participate in the focus group. If I am chosen to participate, I will respect other student's points of view and not share what others have said outside the focus group. I can discuss my own experience in the focus group with my parents, but I will not talk about what other students said to my parents. The focus group will be recorded and all the words will be written out in a transcript for my teacher to use to understand how I feel about learning another language. The focus group will be led by the Teacher on Special Assignment in the school, not by Sra. Philipp. The focus group will take place after school in Sra. Philipp's classroom in Middle School. The focus group will last no longer than 60 minutes.

$\checkmark$ I am taking part in this study because I want to.

$\checkmark$ I understand that my parents or guardian have also said it will benefit me.

$\checkmark$ I have been told that I can stop my participation at any time, and if I do not like a question, I do not have to answer it. 
$\checkmark$ All I have to do is to tell my teacher, Sra. Philipp, or the focus group Teacher on Special Assignment, that I want to stop and not participate.

$\checkmark$ My participation in this study will not in any way affect my grade or my relationship with my teacher or my relationship with the School District, Middle School, and my class, the Dual Language Humanities.

If you are selected to be part of the study, your responses (\#1 to \#4) above will be separated from the rest of the classes' responses. Your name and what you tell us will be kept confidential to the extent allowed by law. (By "kept confidential" we mean that the names of the students who take part in this study will not be given to anyone else. And it means that we will only reveal what you say in a way that no one could ever guess or know it was you who said it.) If, in the course of the study during the collection of information (\#1 to \#5 above), you tell me that you are, or are intending to, harm yourself or others, we are ethically and legally required to notify the appropriate authorities.

Your name and other personal information, which we need to keep track of who we talk to, will be kept in a locked file cabinet and in a password protected file on Sra. Philipp's personal computer so that no one other than the researcher staff will be able to see it. For example, this form (which has your name on it) will be kept in a locked file cabinet.

\section{Any questions?}

If you have any questions about this form or the study, you can talk to the person leading the project at Portland State University, Dannelle D. Stevens, Professor, 503-705-982, stevensd@pdx.edu. You can also contact the Office of Research Integrity of Portland State University about your rights as a research participant (someone who takes part in a study). Hours are 9:00 a.m. to 5:00 p.m. The office is located at Portland State University, Market Center Building, Ste. 620, Portland, OR 97201. The telephone number is $503-725-2227$.

\section{If I sign this form, what does it mean?}

This is called a consent form. Your signature means that:

- You have read and understand what this form says.

- You are willing to take part in the study.

- You know that you do not have to take part in this study. And, even if you agree, you can change your mind and stop at any time. No problem.

- You will get a copy of this form to keep for yourself. 
Participant signature

Date

Participant name, printed

Parent or legal guardian signature Date

Parent or legal guardian name printed 
Appendix D: Formulario de Asentimiento del Estudiante 


\section{Formulario de Asentimiento del Estudiante}

Estoy dispuesto a participar en el estudio llamado "Estudiantes Simultáneos Bilingües de la Escuela Intermedia: Respuestas al 'puente' entre dos idiomas en una clase de inmersión dual en Humanidades". Entiendo que la Sra. Philipp, investigadora de Portland State University (la Universidad Estatal de Portland) espera aprender cómo los estudiantes responden a su bilingüismo para mejorar las estrategias de enseñanza que mejorarán las habilidades de alfabetización en español e inglés. Entiendo que participaré en un panel de discusión que se reunirá una vez en diciembre del 2018. En este panel de discusión, de seis a ocho participantes del estudio, discutiremos nuestras respuestas al "Puente" entre español e inglés en nuestra clase de Humanidades y no hablaré de nuestras respuestas fuera del grupo. Entiendo que nuestra discusión será grabada y luego transcrita para su análisis. También entiendo que responderé una encuesta, haré un dibujo de un estudiante bilingüe y que escribiré sobre mi dibujo. También entiendo que los puntajes de mis evaluaciones durante las actividades de se usarán para el estudio. El estudio tendrá lugar en mi aula de humanidades de sexto grado en _ـ_ Middle School.

Participaré en este estudio porque quiero y mis padres o tutores han dicho que está bien que participe. Me han dicho que puedo dejar de participar en cualquier momento, y si no me gusta una pregunta, no tengo que responderla. Mis respuestas serán confidenciales, excepto en el caso de sospecha de negligencia o abuso.

Nombre

Firma

Fecha:

Edad: 
Appendix E: Parent and Guardian Consent Form 


\section{Parent \& Guardian Consent Form}

\section{PARENTAL PERMISSION}

\section{Simultaneous Bilingual Middle School Students: Responses to "the Bridge" Strategy between Two Languages in a Humanities Dual Language Immersion Class}

During this fall (September to December 2018), your child is invited to participate in a research study conducted by Alma Lucinda Philipp, the co-principal investigator, from Portland State University, Curriculum and Instruction Department who is your child's teacher in the Dual Language Immersion Class at $ـ \quad$ School in School District. The researcher hopes to learn how your child, as a simultaneous bilingual middle school student, responds to "the Bridge" strategy. This strategy means making comparisons and connections between English and Spanish languages in a humanities dual language/immersion class to advance literacy in both languages. This study is being conducted in partial fulfillment of the requirements for a doctoral degree, and is under the supervision of Dr. Dannelle D. Stevens, Professor Emerita, Portland State University. Your child was selected as a possible participant in this study, because your child has had at least three years of bilingual education. This means that your child has basic knowledge of English and Spanish languages and your child is enrolled in the middle school dual language immersion program.

Sra. Philipp, the co-principal investigator, will collect these consent forms from all the parents who approve of their child's participation. Sra. Philipp, the co-principal investigator, will also collect assent forms from the students themselves. For a student to participate, Sra. Philipp will need both the parent consent form and the student assent form. However, given the study design, not all the students whose parents approve of their participation and students who give assent to participate will ultimately be in the study. Only six to eight students will be the participants in the study. The goal of the study is to understand more about your child who is becoming literate in two languages. Sra. Philipp, the co-principal investigator, will collect five different kinds of information from your child from September to December 2018. 
1. Three sample assignments from his/her work using the Bridge strategy over eight-week period during September and October. The purpose of collecting the sample assignments is to see how your child transfers what he or she is learning in Spanish and how he or she applies that learning to advance their literacy in English.

2. The results from a survey about how he or she thinks about learning another language conducted in November 2018. The purpose of the survey is to have your child describe how he or she feels about learning to read and write in two languages.

3. His or her drawing of a bilingual student collected in November 2018. The purpose of the drawing is to help your child express his or her internal images of being a bilingual student that are not bound to words. Images sometimes tap different ideas that are not usually expressed in words.

\section{A written description of his or her drawing collected with the drawing in}

November 2018. This will be collected at the same time as the drawing in November 2018. The purpose of the written description of the drawing (Item \#3) is so that I can make sure I do not misinterpret their drawings.

The above four items will be collected from all students in Sra. Philipp's class during class time. The Bridge lessons will go from September to October 2018 (eight weeks). However, if your child one of the six to eight students selected for the study, Sra. Philipp, the co-principal investigator, will separate out his or her responses from the rest of the class to analyze them. The responses from items \#1 to 4 above will be stored in a locked file cabinet at the home office of Sra. Philipp.

5. If your child is one of the six to eight selected for the study, then, he or she will participate in a small group discussion called a focus group in December 2018. The discussion will be recorded digitally and a transcript will be written out of what the children have said. The recording and transcript will remain on coprincipal investigator's password-protected computer. The purpose of the focus 
group is to facilitate a discussion among the students about how they feel, what are their experiences, and what they think about learning two languages, especially how the Bridge strategy works for them.

During the focus group, your child will be asked to respect other student's points of view and not share what others have said outside the focus group. In addition, your student may talk to you about his or her responses; however, to respect the privacy of the other students in the group, we will tell your child to not talk to you about what other students said in the focus group. The focus group will be led by JoAnna Flores, the School District Teacher on Special Assignment, not by Sra. Philipp. Ms. Flores is conducting the focus group so that students can share freely and not give answers to please the teacher. The focus group will take place after school in Sra. Philipp's classroom in $\quad$ Middle School. The focus group will last no longer than 60 minutes.

While participating in this study, it is possible your child may feel uncomfortable about thinking and talking about being bilingual as well as uncomfortable about what may happen to what they have written, drawn and said in the study. The co-principal investigator. Sra. Philipp, will minimize this discomfort by making sure that your child knows that she is keeping the data collected confidential in a locked file cabinet or password-protected computer. In addition, she will tell them that she will not use your child's real name in any results that are found or ideas shared.

There are no costs to participate in this study nor any compensation for you or your child. Your child's participation is voluntary. He/she does not have to take part in this study. Your child may withdraw his or her assent at any time. Your child may stop his/her participation at any time, and if he or she does not like a question, he or she does not have to answer it. All your child has to do is to tell his or her teacher, Sra. Philipp, or Ms. Flores, the focus group Teacher on Special Assignment, that he or she wants to stop and not participate. Your child's participation in this study will not in any way affect his or her grade or his or her relationship with the teacher or with the 
Humanities.

Your child may not receive any direct benefit from taking part in this study, but the study may help to increase knowledge that may help others in the future.

Any information that is obtained in connection with this study and that can be linked to your child or identify your child will be kept confidential and will be disclosed only with your permission or as required by law. It is the investigator's legal obligation to report child abuse, child neglect, elder abuse, harm to self or any life-threatening situation to the appropriate authorities, and; therefore, the confidentiality will not be maintained. This information will be kept confidential by using pseudonyms in the study. Data from the study will be locked in a file cabinet at Sra. Philipp's home and electronic information will be on Sra. Philipp's password protected computer.

If you have questions or concerns about your child's participation in this study, contact me at School. My email is almalucinda philipp@.k12.or.us. The principal investigator for the study is Dr. Dannelle D. Stevens, Professor Emerita, Department of Curriculum and Instruction. Her email is stevensd@pdx.edu, 503-7059828. If you have concerns about your child's rights as a research subject, please contact the PSU Office of Research Integrity, Market Center Building Ste. 620, Portland State University, (503) 725-2227.

Your signature indicates that you have read and understand the above information and agree to let your child take part in this study. The researcher will provide you with a copy of this form for your own records. 
Participant Printed Name

Parent Signature

Date

Parent Printed Name 
Appendix F: Permiso de los Padres 


\section{Permiso de los Padres}

Estudiantes Simultáneos Bilingües de la Escuela Intermedia: Respuestas a la Estrategia "Puente" entre Dos Idiomas en una Clase de Inmersión Dual en Humanidades. Se invita a su hijo a participar en un estudio de investigación conducido por Alma Lucinda Philipp de la Universidad Estatal de Portland, Departamento de Currículo e Instrucción. El investigador espera aprender cómo su hijo como un estudiante bilingüe simultáneos de escuela intermedia responde a la estrategia "Puente"; esta estrategia significa hacer comparaciones y conexiones entre los idiomas inglés y español en una clase de lenguaje dual / inmersión en humanidades para avanzar en la alfabetización en ambos idiomas. Este estudio se lleva a cabo en cumplimiento parcial de los requisitos para un título de doctorado, y está bajo la supervisión de la Dra. Dannelle D. Stevens [indique lo que el estudio está diseñado para descubrir o establecer; si es estudiante, indique también que el estudio se realiza en cumplimiento parcial de los requisitos para obtener un título de maestría o doctorado, e indique que está bajo la supervisión de un miembro específico de la facultad en la PSU]. Su hijo fue seleccionado como posible participante en este estudio porque su hijo ha tenido al menos tres años de educación bilingüe, esto significa que su hijo tiene conocimientos básicos de inglés y español y su hijo está inscripto en el programa de inmersión en dos idiomas de la escuela intermedia.

Si decide dejar que su hijo participe, se le pedirá que asista a un grupo de enfoque que se reunirá solo una vez en diciembre de 2018 para analizar su respuesta al Puente en su avance hacia la alfabetización bilingüe. Este grupo de enfoque constará de seis a ocho estudiantes y sus respuestas se grabarán digitalmente en una unidad flash USB para su transcripción y análisis. El grupo de enfoque se reunirá después de la escuela en el aula B-10 en Para proteger la validez del estudio, el grupo de enfoque será dirigido por JoAnna Flores, una maestra en asignación especial del Departamento Bilingüe del Distrito Escolar de Además, los estudiantes responderán a uno de cada uno de los siguientes: una encuesta de veinte afirmaciones en una escala verbal del 1 al 5 (totalmente en desacuerdo para totalmente de acuerdo); los estudiantes dibujarán a un estudiante bilingüe; $y$, por último, los estudiantes escribirán una descripción de su dibujo. 
Los estudiantes participarán en lecciones regulares de Humanidades en dos idiomas y sus puntajes de evaluaciones sumativas se usarán para el estudio. El propósito de estas cinco actividades (Grupo de Enfoque, Encuesta, Dibujar un Estudiante Bilingüe, Escritura Gratuita, Lecciones de Humanidades de Lenguaje Dual de Bridge) es triangular los resultados para aumentar la confiabilidad en el estudio. [describir procedimientos y actividades, su propósito, duración, ubicación y frecuencia; si se van a grabar estas actividades, indique la forma en que se grabarán: audio, video, ambos, etc.]. Al participar en este estudio, es posible que su hijo se sienta incómodo al contrastar español e inglés. Minimizaré las molestias al mantener confidenciales los datos recopilados y no utilizar el nombre de su hijo en ningún resultado que se encuentre o compartir ideas. [describa todos los posibles riesgos, incomodidades e inconvenientes, y explique cómo protegerá contra ellos; describir cualquier procedimiento alternativo o curso de tratamiento, si corresponde]. No hay costos para participar en este estudio ni compensaciones por participar en este estudio. Es posible que su hijo no reciba ningún beneficio directo de participar en este estudio, pero el estudio puede ayudar a aumentar el conocimiento que puede ayudar a otros en el futuro.

Cualquier información que se obtenga en conexión con este estudio y que pueda vincularse con su hijo o identificar a su hijo se mantendrá confidencial y se divulgará solo con su permiso o según lo exija la ley. Es obligación legal del investigador denunciar a las autoridades competentes el abuso infantil, el abandono infantil, el maltrato a personas mayores, el daño a sí mismo o cualquier situación que ponga en peligro la vida; por lo tanto, la confidencialidad no se mantendrá. [Si este no es el caso, y los sujetos serán identificados por su nombre o de otra forma en un artículo, tesis, disertación, revista o artículo periodístico, en la web o en una presentación, se debe agregar una declaración a tal efecto. Si la información se divulgará a cualquier otra parte por cualquier razón, indique la naturaleza de dicha información, identifique a la persona o agencia a la que se le proporcionará, y el propósito de dicha divulgación. Esta información se mantendrá confidencial mediante el uso de seudónimos. en el estudio. Los datos del estudio se guardarán en un archivador y la información electrónica estará protegida por contraseña. 
La participación de su hijo es voluntaria. Él / ella no tiene que tomar parte en este estudio, y no afectará su calificación o relación con la clase o con el Distrito Escolar de , la Escuela mi clase de Humanidades de Lenguaje Dual, o yo, Alma Lucinda Philipp. También puede retirar su permiso para que su hijo participe de este estudio en cualquier momento sin afectar su grado o relación de curso [grado o relación del curso] con el Distrito Escolar de —_ , la Escuela — mi clase Humanidades de Lenguaje Dual, o yo mismo, Alma Lucinda Philipp [institución u organización mencionada anteriormente]. Asimismo, su hijo puede retirar su consentimiento en cualquier momento sin afectar su grado de curso o relación [grado o relación del curso] con el Distrito Escolar de _ _ _ _ School, mi clase Dual Language Humanities, o conmigo, Alma Lucinda Philipp.

Si tiene preguntas o inquietudes sobre la participación de su hijo en este estudio, contácteme en $\quad$ School. Mi correo electrónico es almalucinda philipp@, .k12.or.us. Mi asesora en la Universidad Estatal de Portland es la Dra. Dannelle D. Stevens. Su correo electrónico es stevensd@pdx.edu. [nombre del investigador] en [dirección y número de teléfono]. Si tiene inquietudes sobre los derechos de su hijo como sujeto de investigación, comuníquese con la Oficina de Integridad de Investigación de la PSU, Market Center Building Ste. 620, Portland State University, (503) 7252227.

Su firma indica que ha leído y comprende la información anterior y acepta permitir que su hijo participe en este estudio. El investigador debe proporcionarle una copia de este formulario para sus propios registros.

Firma del participante Fecha

Nombre impreso del participante 
Nombre impreso del familiar o tutor 
Appendix G: Lesson Plan to Use the Bridge Instructional Strategy 


\section{Lesson Plan to Use the Bridge Instructional Strategy}

I taught a unit of study in Spanish for 3 weeks on the topic of immigration and social justice. Following the structure of the Bridge, before the Bridge I provided prompts for students to talk about what they know about immigration and social justice. Students read "Cajas de carton” by Francisco Jiménez where I integrated state and district standards and finally collected a summative assessment of personal narratives.

Then, I strategically guided students to observe and identify similarities and differences between Spanish and English to connect content to English. After the Bridge, students read Iqbal by Francisco D’Adamo. The recognition of cognates, translanguaging, code-mixing, compare and contrast languages, and use of one language to explain the other was encouraged. 
Appendix H: Narrative Writing Checklist 
Name:

Date:

\begin{tabular}{|c|c|c|c|c|}
\hline \multicolumn{5}{|c|}{ Narrative Writing Checklist } \\
\hline & Grade 6 & $\begin{array}{l}\text { NOT } \\
\text { YET }\end{array}$ & $\begin{array}{c}\text { STARTING } \\
\text { TO }\end{array}$ & YES! \\
\hline & Structure & & & \\
\hline Overall & $\begin{array}{l}\text { I wrote a story that has tension, resolution, realistic characters, and also conveys an idea, } \\
\text { lesson, or theme. }\end{array}$ & $\square$ & $\square$ & $\square$ \\
\hline Lead & $\begin{array}{l}\text { I wrote a beginning that not only set the plot/story in motion, but also hinted at the } \\
\text { larger meaning the story would convey. It introduced the problem, set the stage for the } \\
\text { lesson that would be learned, or showed how the character relates to the setting in a } \\
\text { way that matters in the story. }\end{array}$ & $\square$ & $\square$ & $\square$ \\
\hline Transitions & $\begin{array}{l}\text { I not only used transitional phrases and clauses to signal complicated changes in time, I } \\
\text { also used them to alert my reader to changes in the setting, tone, mood, point of view, or } \\
\text { the time in the story (such as suddenly, unlike before, if only she had known). }\end{array}$ & $\square$ & $\square$ & $\square$ \\
\hline Ending & $\begin{array}{l}\text { I wrote an ending that connected to what the story is really about. I gave the reader a } \\
\text { sense of closure by showing a new realization or insight, or a change in the character/ } \\
\text { narrator. I might have shown this through dialogue, action, inner thinking, or small } \\
\text { actions the character takes. }\end{array}$ & $\square$ & $\square$ & $\square$ \\
\hline \multirow[t]{2}{*}{ Organization } & $\begin{array}{l}\text { I used paragraphs purposefully, perhaps to show time and setting changes, new parts of } \\
\text { the story, or to create suspense for readers. I created a logical, clear sequence of events. }\end{array}$ & $\square$ & $\square$ & $\square$ \\
\hline & Development & & & \\
\hline Elaboration & $\begin{array}{l}\text { I developed realistic characters, and developed the details, action, dialogue, and internal } \\
\text { thinking that contribute to the deeper meaning of the story. }\end{array}$ & $\square$ & $\square$ & $\square$ \\
\hline \multirow[t]{4}{*}{ Craft } & $\begin{array}{l}\text { I developed some relationship between characters to show why they act and speak as } \\
\text { they do. I told the internal, as well as the external story. }\end{array}$ & $\square$ & $\square$ & $\square$ \\
\hline & $\begin{array}{l}\text { I wove together precise descriptions, figurative language, and some symbolism to help } \\
\text { readers picture the setting and actions, and to bring forth meaning. }\end{array}$ & $\square$ & $\square$ & $\square$ \\
\hline & $\begin{array}{l}\text { I used language that fit my story's meaning and context (for example, different } \\
\text { characters use different kinds of language). }\end{array}$ & $\square$ & $\square$ & $\square$ \\
\hline & Conventions & & & \\
\hline Spelling & I used resources to be sure the words in my writing are spelled correctly. & $\square$ & $\square$ & $\square$ \\
\hline \multirow{2}{*}{$\begin{array}{l}\text { Punctuation } \\
\text { and Sentence } \\
\text { Structure }\end{array}$} & $\begin{array}{l}\text { I used punctuation such as dashes, parentheses, colons, and semicolons to help me } \\
\text { include extra detail and explanation in some of my sentences. }\end{array}$ & $\square$ & $\square$ & $\square$ \\
\hline & $\begin{array}{l}\text { I used commas and quotation marks or italics or other ways to make clear when } \\
\text { characters are speaking. }\end{array}$ & $\square$ & $\square$ & $\square$ \\
\hline
\end{tabular}


Appendix I: Survey in Form of a Verbal Scale Response 


\section{Survey in Form of a Verbal Scale Response}

How do students respond to "the Bridge" activities?

Please rate these statements on a scale from 1 to 5 ( 1 strongly disagree to 5 strongly agree)

\section{Performance}

a. Using the 'cognates' strategy from 'the Bridge' has helped me better utilize one language to improve my literacy in the other.

b. Using the 'translanguaging' strategy from 'the Bridge' has helped me better utilize one language to improve my literacy in the other.

c. Using the 'code mixing' strategy from 'the Bridge' has helped me better utilize one language to improve my literacy in the other.

d. Using the 'use one language to explain the other one' strategy from 'the Bridge' has helped me better utilize one language to improve my literacy in the other.

e. Using the strategies from 'the Bridge' has helped me better utilize one language to improve my literacy in the other.

2. Confidence (self-efficacy)

a. I feel that I can confidently express myself in English.

b. I feel that I can confidently express myself in Spanish.

c. I feel that I can confidently express myself during class.

d. It is important to practice - I am not afraid to make mistakes.

e. I can rely on my English to help me understand and respond in Spanish and the other way round.

3. Attitude/Pride (self-esteem)

a. It is important for me to learn Spanish.

b. I feel proud to be able to speak Spanish.

c. I am proud that I can speak two languages.

d. My life is richer, because I speak two languages. 
e. Speaking Spanish makes me feel more connected to my Hispanic community.

4. Motivation
a. I would like to learn more about my Hispanic heritage.
b. I would like to do as well academically in Spanish as I do in English.
c. Learning Spanish is important to me.
d. Being bilingual will be of great benefit to my career.
e. It is important to my parents that I am bilingual.

* Adapted from Gardner, R. C. \& Lambert, W. E. (1972). Attitudes and motivation in second-language learning. Rowley, Massachusetts: Newbury House Publishers. Research on attitudes and motivations to learn a second language. 
Appendix J: Draw-a-Bilingual Student Form 


\section{Draw-a-Bilingual Student Form}

En este espacio, dibuja a un estudiante bilingüe. 
Appendix K: Free Narrative Form 


\section{Free-Narrative Form}

Describe el dibujo que hiciste de un estudiante bilingüe. 
Appendix L: Focus Group Protocol and Questions 


\section{Focus Group Protocol}

Thank you for being in here and thinking together about what it means to be a bilingual student. I am JoAnna Flores, a School District Teacher on Special Assignment for the Bilingual Department. I am conducting the focus group so that you can share freely and not feel that you need to please Sra. Philipp. She hopes to learn how you, as a simultaneous bilingual middle school student, responds to "the Bridge" strategy. You have already done activities using the Bridge, completed the survey, and you have drawn and described a bilingual student. So this is the last part of the study and is a chance for you to think together about the Bridge strategy. This should not take longer than an hour.

Being bilingual is very special and you have important information to share. During our time together please respect other student's points of view and not share what others have said outside the room. I will do the same. You can discuss your own experience in this group with your parents, but please, do not talk about what other students said with your parents or with each other. This means, once we are done today, you should not talk with other students in the halls or in class about what we said here. The focus group will be recorded and all the words will be written out in a transcript for Sra. Philipp to understand how you feel about learning another language. Sra. Philipp will be the only one to listen and learn about how you feel about being a bilingual student.

There are no right or wrong answers to my questions. For example, if I ask you your favorite color, or if someone asks if you like chocolate or vanilla ice cream, there is no right or wrong answer. So whatever you tell me when I ask you these questions, is exactly what you should be telling me.

Our discussion will be recorded using this iPad and this iPhone. Then, Sra. Philipp will write down what you said. She will keep the recording and the written record in her computer. We want you to talk to each other about how you feel, what your experiences have been, and what you think about learning two languages, especially how the Bridge strategy works for you.

While participating in this study, it is possible you may feel uncomfortable about thinking and talking about being bilingual as well as uncomfortable about what may happen to what you have written, drawn and said in the study. Sra. Philipp will not use your real name in any results that she finds or ideas shared. You are here voluntarily. If you decide you don't want to be here, you can leave at any time. If you do not like a question, you do not need to answer it. All you need to do is tell me that you want to stop and not participate. Whether you participate or not will not affect your grade or relationship with Sra. Philipp or School.

Do you have any questions for me before we start? 


\section{Focus group guiding questions:}

a) With whom do you speak in English and with whom in Spanish?

b) What are you more comfortable talking about in Spanish and what in English?

c) Describe how your family, friends, and teachers support you in becoming bilingual.

d) Tell me what activities from 'the Bridge' -cognates, translanguaging, code mixing, use one language to explain the other one- help you improve your reading and writing in Spanish and English.

e) Tell me about your motivation to learn Spanish.

f) Tell me about a couple situations where you feel being bilingual has been helpful to you. 
Appendix M: Survey Data Analysis 


\begin{tabular}{|c|c|c|}
\hline Survey Data Analysis & & \\
\hline & average & std dev \\
\hline A. Performance & & \\
\hline $\begin{array}{l}\text { A1. Using the 'cognates' strategy from 'the Bridge' has helped me better utilize one language to } \\
\text { improve in the other. }\end{array}$ & 3.75 & 0.75 \\
\hline $\begin{array}{l}\text { A.2. Using the 'translanguaging' strategy from 'the Bridge' has helped me better utilize one language } \\
\text { to improve my literacy in the other. }\end{array}$ & 4.00 & 0.85 \\
\hline $\begin{array}{l}\text { A3. Using the 'code mixing' strategy from 'the Bridge' has helped me better utilize one language to } \\
\text { improve my literacy in the other. }\end{array}$ & 3.75 & 0.87 \\
\hline $\begin{array}{l}\text { A4. Using one language to explain the other one from 'the Bridge' has helped me better understand } \\
\text { one language to improve my literacy in the other. }\end{array}$ & 4.17 & 0.83 \\
\hline $\begin{array}{l}\text { A5. Using the strategies from 'the Bridge' has helped me better utilize one language to improve my } \\
\text { literacy in the other. }\end{array}$ & 4.20 & 0.79 \\
\hline Average rating per student for Performance dimension & 3.97 & 0.82 \\
\hline B. Confidence & & \\
\hline B1. I feel that I can confidently express myself in English. & 4.25 & 0.75 \\
\hline B2. I feel that I can confidently express myself in Spanish. & 4.54 & 0.94 \\
\hline B3. I feel that I can confidently express myself during class. & 3.67 & 1.44 \\
\hline B4. It is important to practice - I amnot afraid to make mistakes. & 4.00 & 0.77 \\
\hline B5. I can rely on my English to help me understand and respond in Spanish and the other w ay round. & 4.00 & 0.74 \\
\hline Average rating per student for Confidence dimension & 4.09 & 0.93 \\
\hline C. Attitude/Pride (self-esteem) & & \\
\hline C1. It is important for me to learn Spanish. & 4.83 & 0.39 \\
\hline C2. I feel proud to be able to speak Spanish. & 4.83 & 0.39 \\
\hline C3. I am proud that I can speak two languages. & 4.75 & 0.45 \\
\hline C4. My life is richer, because I speak two languages. & 4.08 & 0.79 \\
\hline C5. Speaking Spanish makes me feel more connected to my Hispanic community. & 4.50 & 1.00 \\
\hline Average rating per student for Attitude/Pride dimension & 4.60 & 0.60 \\
\hline D. Motivation & & \\
\hline D1. I w ould like to learn more about my Hispanic heritage. & 4.08 & 1.24 \\
\hline D2. I w ould like to do as well academically in Spanish as I do in English. & 4.33 & 0.89 \\
\hline D3. Learning Spanish is important to me. & 4.58 & 0.90 \\
\hline D4. Being bilingual will be of great benefit to my career. & 4.75 & 0.45 \\
\hline D 5. It is imp ortant to my parents that I am bilingual. & 4.67 & 0.65 \\
\hline Average rating per student for Motiv ation dimension & 4.48 & 0.83 \\
\hline 5 strongly agree & & \\
\hline 4 agree & & \\
\hline 3 I don't know & & \\
\hline 2 disagree & & \\
\hline 1 strongly disagree & & \\
\hline
\end{tabular}




\section{Performance}

1. The one item in the performance dimension with the highest level of agreement $\left(\sum=\right.$ $4.20, \mathrm{SD} 0.79$ ) indicates that students know that using one language to learn another helps them to learn both.

2. The one item in the performance dimension with the second highest level of agreement $\left(\sum=4.17\right.$, SD 0.83$)$ indicates that students use one language to explain the other resulting in better understanding one language and improving literacy in the other.

3. The one item in the performance dimension with the second lowest level of agreement $\left(\sum=4.00\right.$, SD 0.85$)$ indicates that using the "Translanguaging" strategy helped students better use one language to improve their literacy in the other.

4. The two items in the performance dimension with the lowest level of agreement indicate that using "cognates" $\left(\sum=3.75, \mathrm{SD} 0.75\right)$ and "code mixing" $\left(\sum=3.75, \mathrm{SD}\right.$ $0.87)$ strategies helped students use one language to improve the other.

Mean of all items in the performance dimension were on the agreement side of the scale, ranged from 3.75 to 4.20 on a 5 -point likert scale.

\section{Confidence}

1. The one item in the confidence dimension with the highest level of agreement $\left(\sum=\right.$ 4.54, SD 0.94) indicates that students feel confident to express themselves in Spanish.

2. The second highest level of agreement item in the confidence dimension $\left(\sum=4.25, \mathrm{SD}\right.$ 0.75 ) indicates that students feel that they can confidently express themselves in English.

3. There are two items with the second lowest level of agreement in the confidence dimension. One indicates that it is important for students to practice - they are not afraid to make mistakes $\left(\sum=4.00\right.$, SD 0.77$)$. The other one indicates that students can rely on their English to help them understand and respond in Spanish and the other way round $(\Sigma$ $=4.00, \mathrm{SD} 0.74)$.

4. The item with the lowest level of agreement in the confidence dimension indicates that students feel that they can confidently express themselves during class $\left(\sum=3.67, \mathrm{SD}\right.$ 1.44).

Mean of all items in the confidence dimension were on the agreement side of the scale, ranged from 3.67 to 4.54 on a 5 -point Likert scale.

\section{Attitude/Pride (self-esteem)}

1. There are two items in the attitude/Pride (self-esteem) dimension with the highest level of agreement. One indicates that it is important for the students to learn Spanish $(\Sigma=$ 
4.83, SD 0.39). The other one indicates that the student feels proud to be able to speak Spanish $\left(\sum=4.83\right.$, SD 0.39).

2. The second item with the highest level of agreement in the attitude/Pride (self-esteem) dimension indicates that the student is proud that she or he can speak two languages $\left(\sum=4.75, \mathrm{SD} 0.45\right)$.

3. The second lowest level of agreement item in the attitude/ Pride (self-esteem) dimension indicates that speaking Spanish makes the student feel more connected to his/her Hispanic community $\left(\sum=4.50, \mathrm{SD} 1.00\right)$.

4. The lowest level of agreement in the attitude/Pride (self-esteem) dimension indicates that students' life is richer, because they speak two languages $\left(\sum=4.08, \mathrm{SD} 0.79\right)$.

Mean of all items in the attitude/pride (self-esteem) dimension were on the agreement side of the scale, ranged from 4.08 to 4.83 on a 5-point Likert scale.

\section{Motivation}

1. The one item with the highest level of agreement in the motivation dimension indicates that for the student being bilingual will be of great benefit to his/her career $\left(\sum=4.75\right.$, SD $0.45)$.

2. The second item with the highest level of agreement in the motivation dimension indicates that it is important for student's parents that he/she is bilingual $\left(\sum=4.67, \mathrm{SD}\right.$ $0.65)$.

3. The third item with the highest level of agreement in the motivation dimension indicates that learning Spanish is important to the student $\left(\sum=4.58\right.$, SD 0.90).

4. The second lowest item in the motivation dimension indicates that the student would like to do as well academically in Spanish as they do in English $\left(\sum=4.33, \mathrm{SD} 0.89\right)$.

5. The lowest level of agreement item in the motivation dimension indicates that students would like to learn more about his/her Hispanic heritage $\left(\sum=4.08\right.$, SD 1.24).

Mean of all items in the motivation dimension were on the agreement side of the scale, ranged from 4.08 to 4.75 on a 5 -point Likert scale. 
Appendix N: Students' Draw-a-Bilingual-Student Pictures and Narratives 


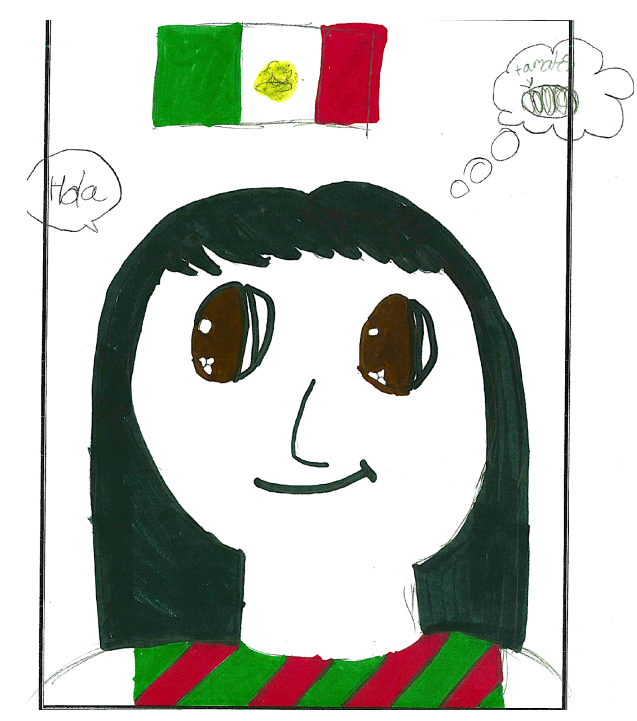

Student 2:

Hello my name is Rose and I just moved from Mexico and I don't rele spec inglish that much but I wode like to larned dot rayt now I wode like to explor Portland and I have to help my perant un pake I have a butiful home I'm so glad I am adol to live in the USA and to go to school faynaly $\mathrm{i}$ had to work in Mexico and if my parint war hays they wode let me go to school but now they have a good job wer they get good mony.

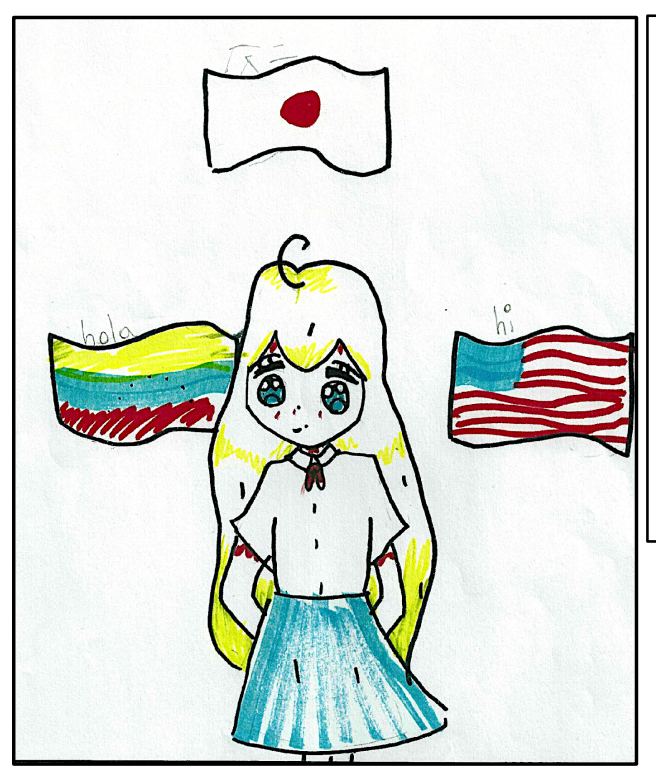

Student 3:

Hi my person Bilingual espaek japan, ingles, and Spanish. 


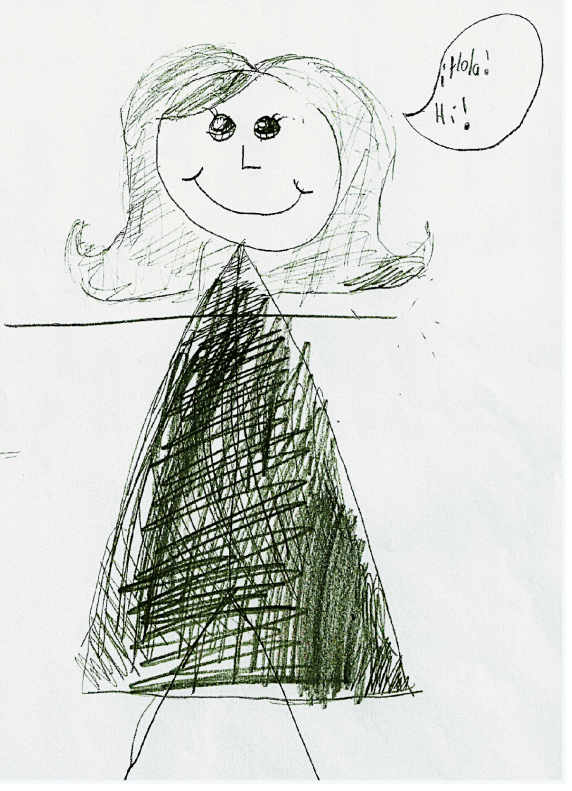

\section{Student 4:}

Mi dibujo es sobre una niña

bilingüe ella esta muy agradecida por ser

bilingüe porque puede casi comunicarse con todos le puede ayudar muchísimo en su carerra porque puede ser mucho como comunicarse explicar y casi no va a tener problemas con su lenguaje y con su raza por esa razón queremos ser belingue yo estoy muy agradecida por tener maestras y la oportunidad de hablar dos lenguaje y apuntis. 


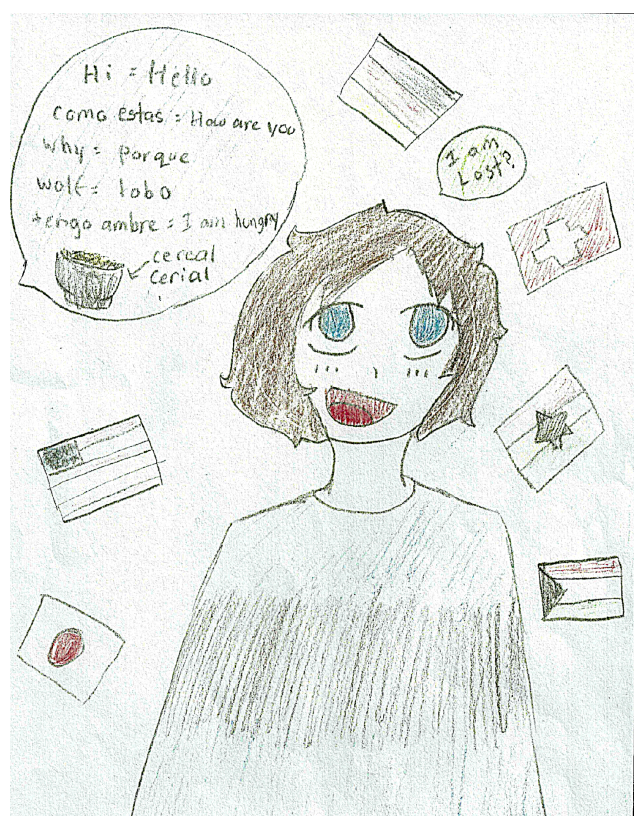

\section{Student 7:}

My person is confused but then learns how to speak many leanguges. he trys to to work on learning every single day so one day he can be a multipul person and learn every single languages. The person trys very hard to learn multipul languaeges and this person is a one fo a kind. He is very good person and never gives up very easily iven do the person gets buliy by other people. Untill one day he trys to go to learn a new language the person is made fun by. He is confused because the person is mean, but a year later past and he has almost learn every state and place he has vecome a very good person and learned so many leanguaeges. Now he nows what people are talking about him. 


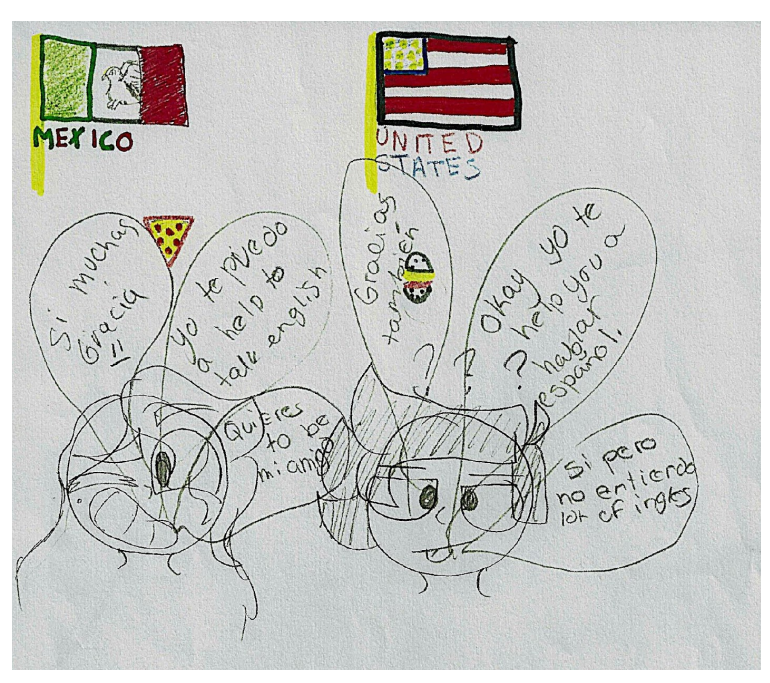

\section{Student 9:}

The drawing that I drew

describes a girl asking a Latin boy if he

wanted to be her friend but she doesn't

really know how to talk Spanish very

well so she mixed English and Spanish

together to ask him and he did the same

thing. For example, she said "Quieres to

be mi amigo" he said "Si pero no

endiendo lot fo English.” Then the girl

said I can help you talk Englsih the boy

said "okay yo te help you a hablar

español. Both of the kids mixed Spanish

and English to help each other

communicate. 


\section{Student 5:}

thi girld is saying she talks 3

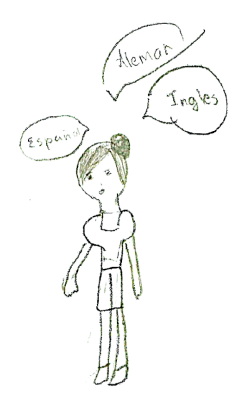

languages and she is proud of that becaused she can say more and life is esay for her. And it esay she can talk 3 languges at forst it was hard buta 11 her hard work paid up.

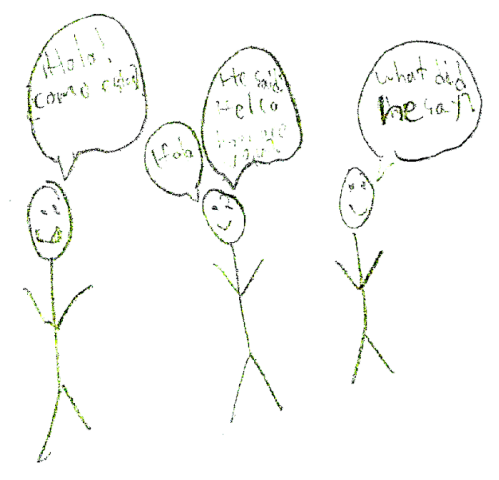

\section{Student 11:}

I believe being bilingual is

being able to translate to someone and be able to go to a country where people speak your $2^{\text {nd }}$ language every day and may not know another and be able to speak fluently with them. Also being able to read and write in that second language. Also you can translaguage for someone and read in another language and then speak and tell what it says in another language. 


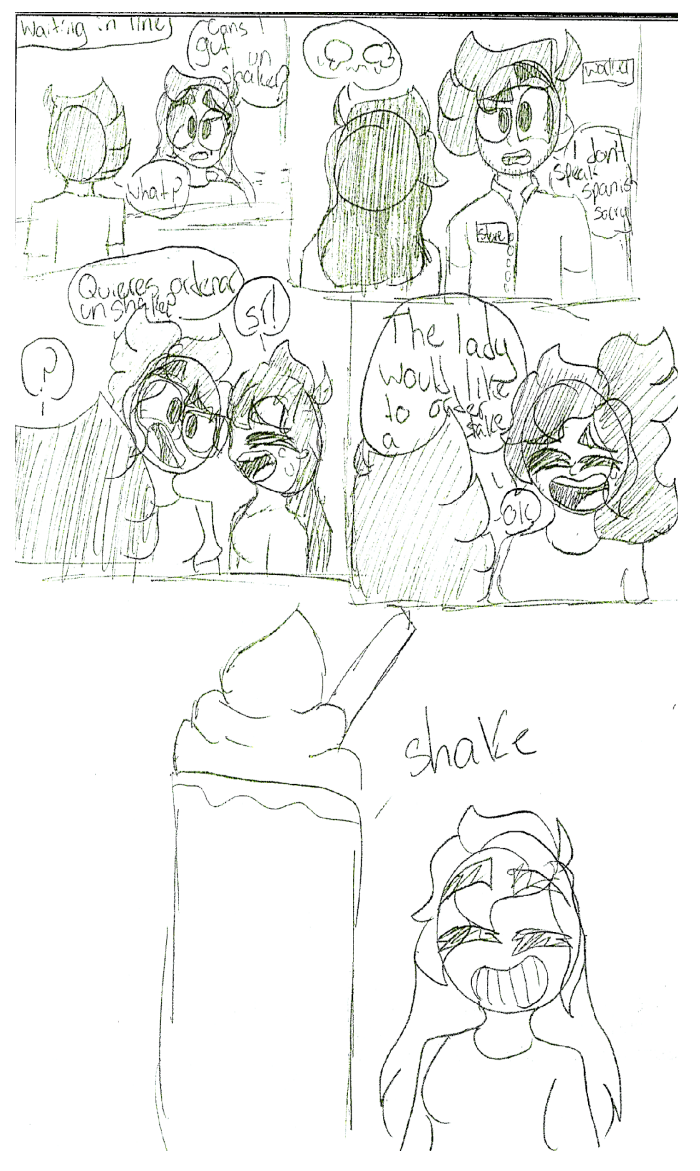

Student 12:

The lady is trying to order

a shake from McDonalds but can't

speak fluent English. When the

worker asks if she can repeat it he

can't understand what she is

saying since he doesn't speake

Spanish. I ask the lady in Spanish

what she wants to order and once

she told me what she wanted to

order, I talked with the worker

with fluent English. 
Appendix O: Student Essays 
Lucinda Philipp

Humanities 6 grade

Narrative in English - 22-sep-2018

14 Ranch

Once I went to a place called 14 Ranch. The ranch was in Wyoming. I was capturing flying grasshoppers when Dave open the gate to the ranch. It was, for me, like opening a door to the past. My great grandpa's brother, Clark owned the ranch before Dave. Clark was a good man and he sold the ranch to Dave a few years before his passing. Anyways, it felt like I had gone back in time because I found old bullet shells that belong to Clark and my great grandpa. They were both hunters and they ate all the food that they caught.

The first night we stayed I could hear all the crickets going "chirp! chirp! chirp!" In the morning, my brother and I liked to catch crickets. "Get the net", I yelled! My brother replied: "You're the closest one to the net!" I said "get the net while I go hurd them." I was going to round them up because I was the fastest.

I would hurd them into a pile and then we would trade off the net to catch them. We let them go after we looked at them for a while. The crickets that we liked to catch were the big ones that like to fly and they also like to puff out their wings. They flew in the front of us slowly and then flew faster when we swung the net. They teased us a lot, and after we got tired they would land in front of us. It seems like they knew that we were tired and that we could not chase them any longer. 


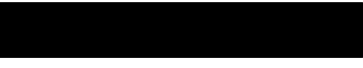

Lucinda Philipp

Humanities 6 grade

$22-\operatorname{sep}-2018$

E1 club Luso Larense

Cuando yo tenía 7 años, fui a Venezuela para visitar a mi familia. Mi primo Dario me invito al club Luso Larense. En el club habia una piscina que tenia muchas monedas adentro del agua.

Las monedas estaban al fondo de la piscina. Mi primo y yo fuimos al fondo de la piscina a buscar las monedas, eran monedas de 10 centavos de Boliv ar. Con esas monedas, nos podiamos comprar un chicle. También, agarramos azulejos y jugamos que eran monedas. Los azulejos son baldosas que cubren la parte interior de la piscina y algunas se cayeron

El y yo nos peleabamos por 'monedas'. De pronto pasó un avión que tenía el ruido como un león

-En ese avión va la prima Tati-, dije yo.

-Pero la prima Tati está aquí Coquito-, dijo mi primo Dario.

Yo sabía que mi prima estaba enfrente de mi, pero me gustaba que me llamaran Coquito. Todavia me gusta, pero ellos dicen que soy muy grande. Mi prima apareció y dijo:

- ¡Ya tienen un millón de azulejos! ¡Van a dejar a la piscina desnuda! -

El club también tenía un tobogán. El tobogán parecía una serpiente grande escupiendo gente de su boca. Cuando yo bajaba en el tobogán, yo me tenía que mov er, para que no le pegara 


\section{Skateboarding}

Skateboarding plays a big part in my life. It all started when I was 8 years old. It was my brothers birthday and he had been asking for a skateboard, but I didn't know what a skateboard was so I was kinda excited to see what it finally is. Everyone just got done eating and now he will open the presents. And so he did. I figured they probably saved the best for last so I waited and I can tell my brother was also waiting. All my brother cared about was the skateboard so he swiped through all the others but... there was no skateboard.I felt really bad. So I was gonna walk up to him and out of nowhere my uncle runs through the door screaming "HAPPY BIRTHDAY". My brother EXPLODES with happiness running towards the skateboard and I followed. Before he left the house he thanked everybody that came. Then he places the skateboard down and hops on and he was surprisingly good for his first try. And now I realized how cool a skateboard was. Of course now I wanted one too but I didnt wanna wait till my birthday. I figured I will buy one with my leftover christmas money. Although I didn't know the price. I quickly asked my uncle and he said the one he bought was 50 dollars. And I only had 39 at the time and I felt bad for asking but I asked my brother for 11 dollars and surprisingly he 


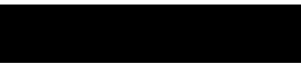

Maestra Philipp

6 Grado DL Humanidades

28 de septiembre

Era una tarde clara y soleada de junio. Algunas días antes termine la escuela.

Después de un bocado de la tarde mi familia: mamá, papá, Elijah, Isaac, Moses, Zechariah y yo sentamos en el sofá.

¡Era el día muy especial! ¡Estábamos esperando para este día por cinco meses! ¡Era el día que aprendimos el género de los gemelos en el estómago de mi mamá! Estaba tan nerviosa como un pajarito aprendiendo a volar. Pero también estaba tan emocionada.

Por fin era tiempo. Los cientos de mariposas en mi estómago tomó vuelo. Los dedos de mi mamá temblaron cuando abrió el sobre. Adentro era la respuesta que cambiaron nuestras vidas para siempre. Adentro era las palabras sí y no. Una estaba circulada. 'Si' significa que había al menos una nifia. 'No' significa que no había ninguna nifía. ¡Yo quería una hermana tanto! No quería otro hermano.

-Hay...- empezo mi madre, abriendo la carta muy despacito.

Mi corazón latía violentamente en mi pecho, ¡como si fuera a explotar!

Adentro había mi sino. Si o no. Si o no.

-¡Cero nifías!-exclamó muy sorprendida. -El 'no' estaba circulado. ¡No hay ninguna niña! Hay dos niños. ¡No lo puedo creer!-

-¡Tú no vas a tener hermana!- gritó la carta, mientras mis hermanos vivos gritaron de alegría. 
Appendix P: Oregon State Seal of Biliteracy 


\section{OREGON STATE SEAL OF BILITERACY}

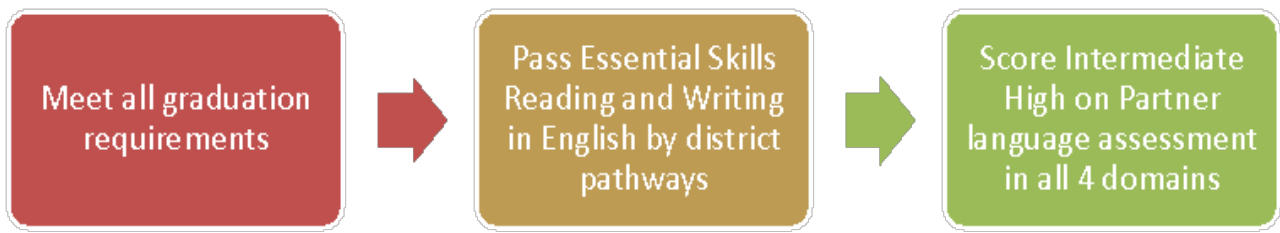

QUALIFYING ASSESSMENTS:

$\forall$ AP Language -4

$\forall \mathrm{IB}-4$

$\forall$ AP Literature -3 iplus a listening/speaking assessment)

$\forall$ ACTFL - Intermediate High score

- AAPPL, CLEP, IB, OPI (plus a reading/writing assessment)

- SLIP, STAMP

$\forall$ PORTFOLIO of Evidence in all 4 domains

$\forall$ Willamette Promise

\section{PROCESS:}

1. Contact ODE to establish the Biliteracy Seal for your districts

2. Assess students in the partner language

3. Collect required data and submit to $\mathrm{ODE}$ via Biliter acy Seal Data Collection

4. Receive certificates and seals

5. Record the Biliteracy Seal on transcript

6. Award certificate as district determines

7. Affix seal on diploma
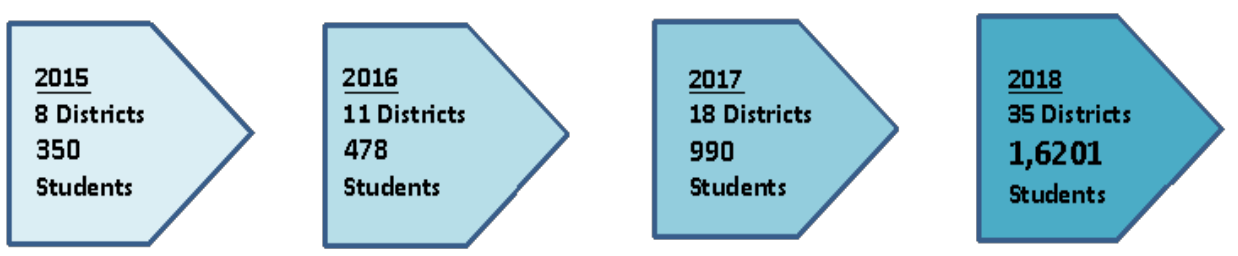

\section{BENEFITS OF THE BIUTERACY SEAL:}

$\forall$ Districts may award World Language credit for partner language proficiency

$\forall$ Depending on partner language assessment, post-secondary language credit

$\forall$ Potential employment considerations

\section{Contact information:}

Oregon State Seal of Biliteracy

Taffy Carlisle - 503-947-5688 or Taffy.Carlisle@state.or.us 
'OAR 581-021-0582 - Established April 2016:

(1) The State Seal of Biliteracy is established to recognize high school graduates who have attained a high level of proficiency in reading, writing, listening, and speaking in one or more World Languages in addition to English. The State Seal of Biliteracy shall be awarded by the Superintendent of Public Instruction. School district participation in this program is voluntary.

(2) The purposes of the State Seal of Biliteracy are as follows:

(a) To encourage students to study languages

(b) To certify attainment of Biliteracy

(c) To provide employers with a method of identifying people with language and Biliteracy skills

(d) To provide post-secondary institutions with a method to recognize and give academic credit to applicants seeking admission

(e) To prepare students to be college and career ready

(f) To recognize and promote world language instruction in public schools

(g) To strengthen intergroup relationships, affirm the value of diversity, and honor the multiple cultures and languages of a community'

Figure P.1. Oregon State Seal of Biliteracy One-Pager. Reprinted from the Oregon Department of Education (2016b). 